\title{
MONTANA \\ PIPING PLOVER \\ MANAGEMENT PLAN
}

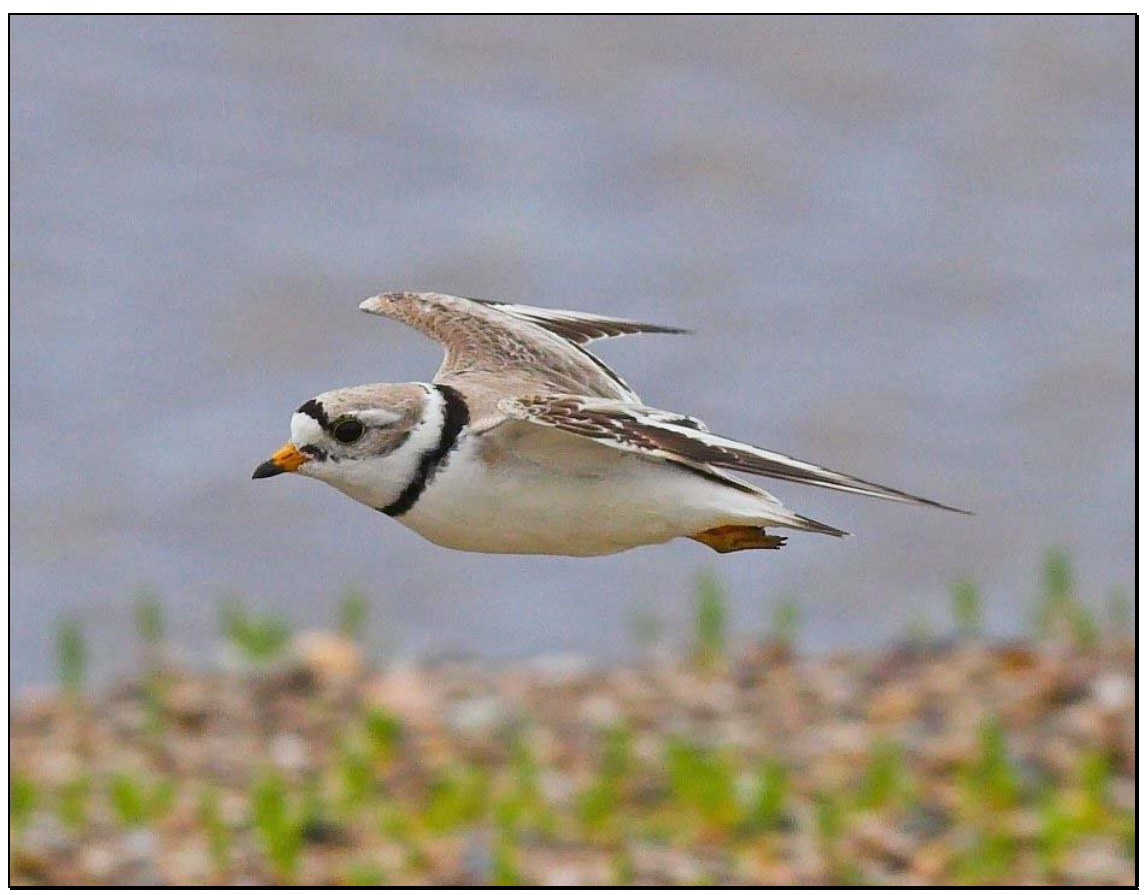

With input from the

Montana Piping Plover

Recovery Committee

APRIL 2006 



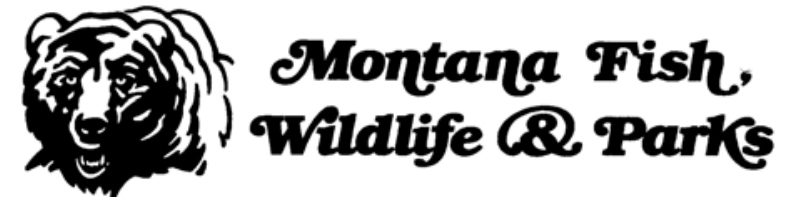

\author{
MONTANA \\ PIPING PLOVER \\ MANAGEMENT PLAN
}

\author{
Prepared by: \\ Shirley J. Atkinson and Arnold R. Dood \\ Montana Department of Fish, Wildlife and Parks \\ 1400 S $19^{\text {th }}$ Ave, Bozeman, Montana
}

With input from the

Montana Piping Plover

Recovery Committee

April 2006 
Suggested Citation: Atkinson, S. J. and Dood, A. R. 2006. Montana Piping Plover Management Plan. Montana Department of Fish, Wildlife and Parks, Bozeman, Montana. 78 pp.

Front Cover Photograph: Male Piping Plover (breeding plumage) in flight. Courtesy: Doug Backlund, Pierre, S.D. 


\section{EXECUTIVE SUMMARY}

The piping plover (Charadrius melodus) is a migratory shorebird endemic to North America. In 1985, it was federally listed under the Endangered Species Act. In the listing, three distinct populations were identified: Atlantic coast and Northern Great Plains populations were listed as threatened while the Great Lakes birds were considered endangered. Birds nesting in Montana are part of the Northern Great Plains population.

Plovers breed on alkali flats, along prairie rivers and on reservoir shorelines in the Northern Great Plains. Within Montana, a complex of alkaline lake and wetland sites in the northeastern part of the state support the greatest numbers of breeding birds in any given year. Reservoir and river reaches on the Missouri

River from Fort Peck Reservoir to the Montana-North Dakota border as well as wetland sites at Bowdoin National Wildlife Refuge and Nelson Reservoir are also used when water and habitat conditions are suitable.

In order to support national recovery objectives, Montana established a goal of maintaining 120 adults (60 pairs) over a ten-year running average. While monitoring efforts over the past decade suggest that the State has met its goal, habitat use by plovers is dynamic. Birds tend to be opportunistic and disperse across the landscape in response to changes in water levels and habitat availability. In light of such a dispersal response, the potential resource Montana's alkali wetlands and reaches of the Missouri provide to breeding birds during years characterized by abnormal weather and water conditions elsewhere is invaluable. This plan recommends specific management and research activities, that we believe are necessary to sustain the population as well as aid long term recovery efforts.

The following recommendations are discussed as a multifaceted approach to managing piping plover breeding habitat and increasing levels of productivity within the State of Montana:

i. continued annual monitoring of plovers coupled with efforts to standardize monitoring and data collection techniques within and between states/provinces in the Northern Great Plains

ii. integrating landscape level approaches into plover management

ii. continued site specific use of predator management deterrent and control measures

iii. management of water flows that restore riverine habitats and their associated ecosystem processes

iii. management of vegetation encroachment and substrate to increase nest site availability

iv. providing assistance to private landowners interested in implementing voluntary conservation measures that improve wetland habitat and limit livestock disturbance

v. habitat and site specific investigations of factors influencing productivity such as predation and forage availability. 


\section{ACKNOWLEDGEMENTS}

The Montana Piping Plover Management Plan was prepared for the Montana Department of Fish, Wildlife and Parks by Shirley Atkinson and Arnold Dood, with input from the Montana Piping Plover Recovery Committee. Many people assisted in the compilation of this plan by providing data, reports, and invaluable insight. We are grateful for the information and support provided by the following: Bobby Baker (BLM), Lou Hanebury (USFWS), Jake Ivan (USFWS), Karen Kreil (USFWS), Casey Kruse (USACE), Greg Pavelka (USACE), Fritz Prellwitz (BLM), Nell McPhillips (USFWS), Mike Rabenberg (USFWS), Adam Ryba (USFWS), Dale Tribby (BLM) and Kathy Tribby (USFWS). Our thanks are also extended to all who participated in surveys in Montana with the Piping Plover Recovery Committee and to John Ensign (MFWP), Dave Fuller (MFWP), Bernie Hildebrand (MFWP), Coleen O'Rourke (MFWP), Helga Pac (MFWP), Ryan Rauscher (MFWP), Victor Riggs (MFWP) and Brad Schmitz (MFWP). This report draws heavily upon work from various authors and completion of this project would not have been possible without the dedication and research conducted by them. Financial support for this project came from the Montana Department of Fish, Wildlife and Parks and the United States Fish and Wildlife Service, under Section 6 of the Endangered Species Act. 


\section{TABLE OF CONTENTS}

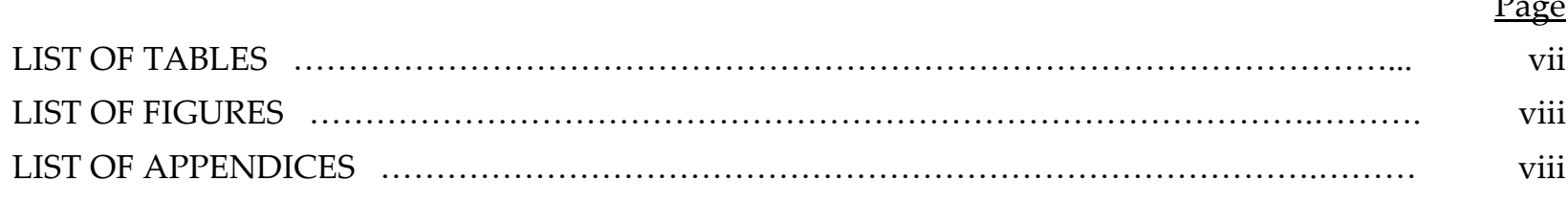

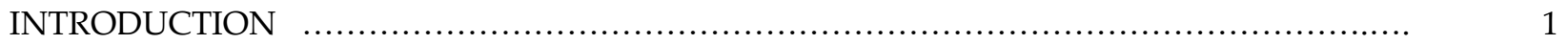

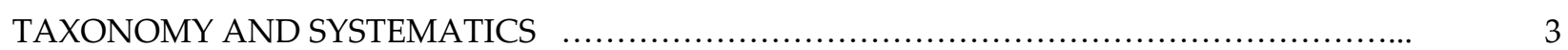

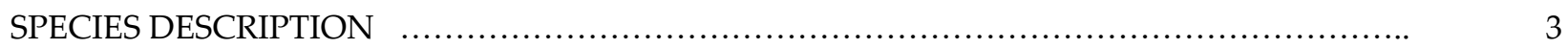

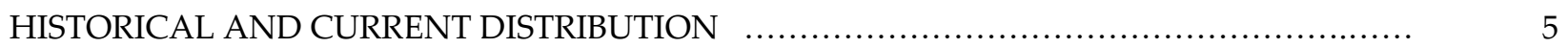

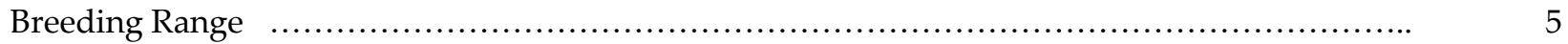

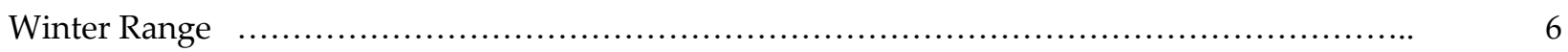

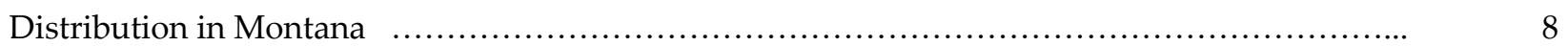

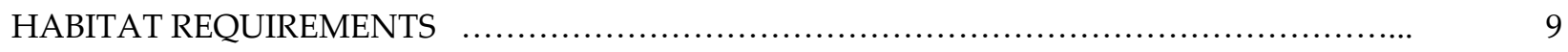

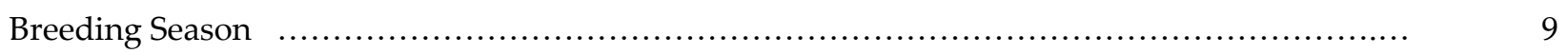

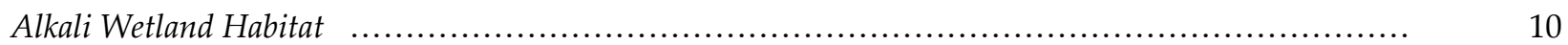

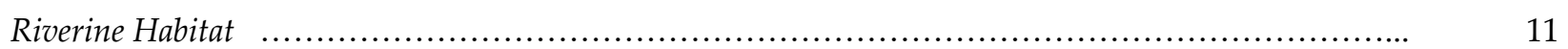

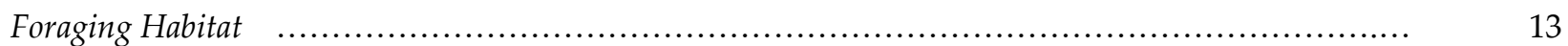

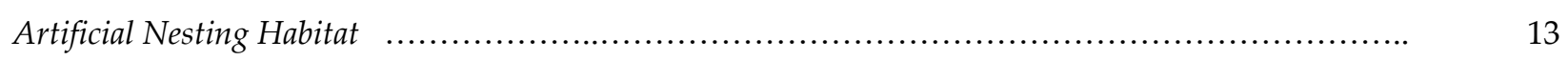

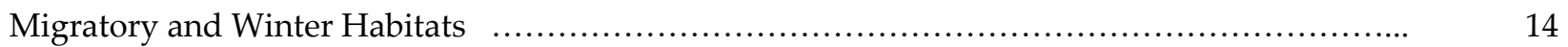

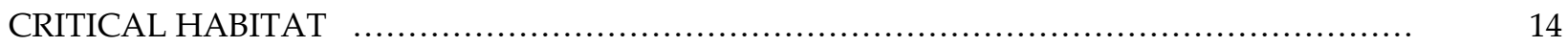

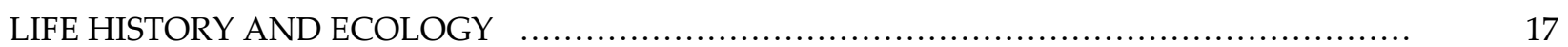

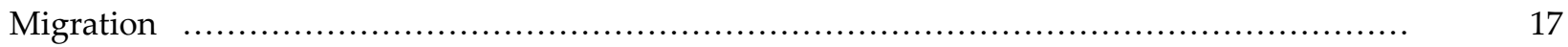

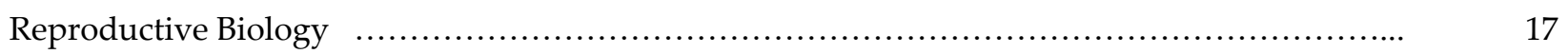

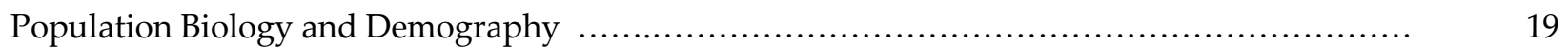

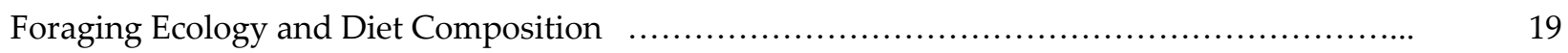

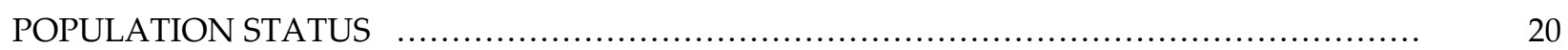

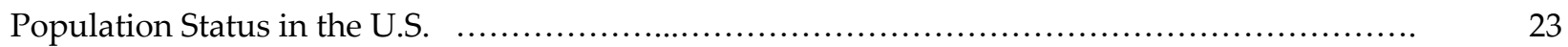

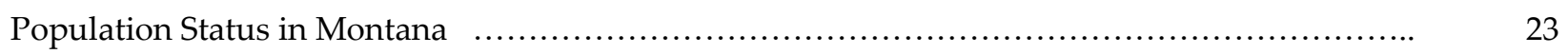

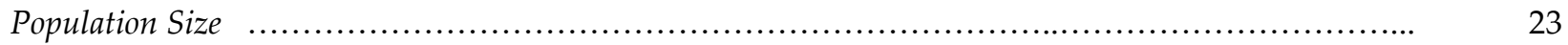

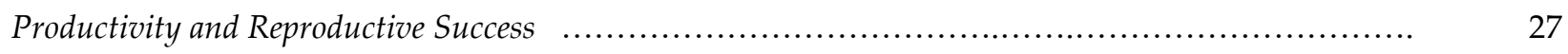

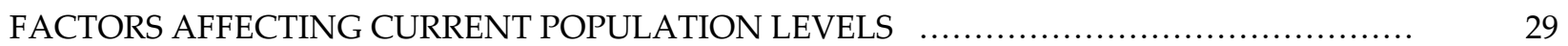

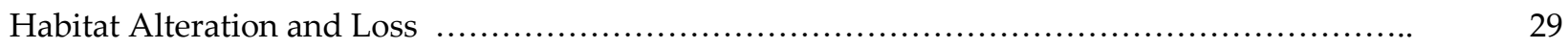

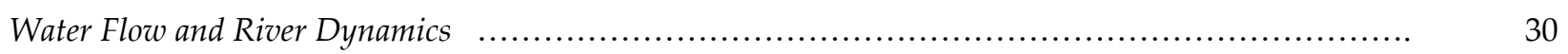

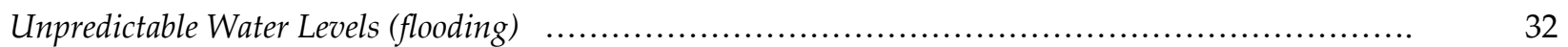

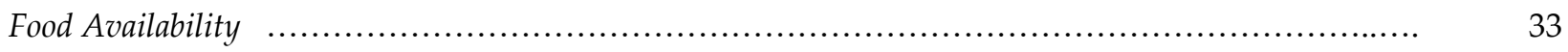

Alkali Wetland Loss and Modification ........................................................... 


\section{TABLE OF CONTENTS (CONT)}

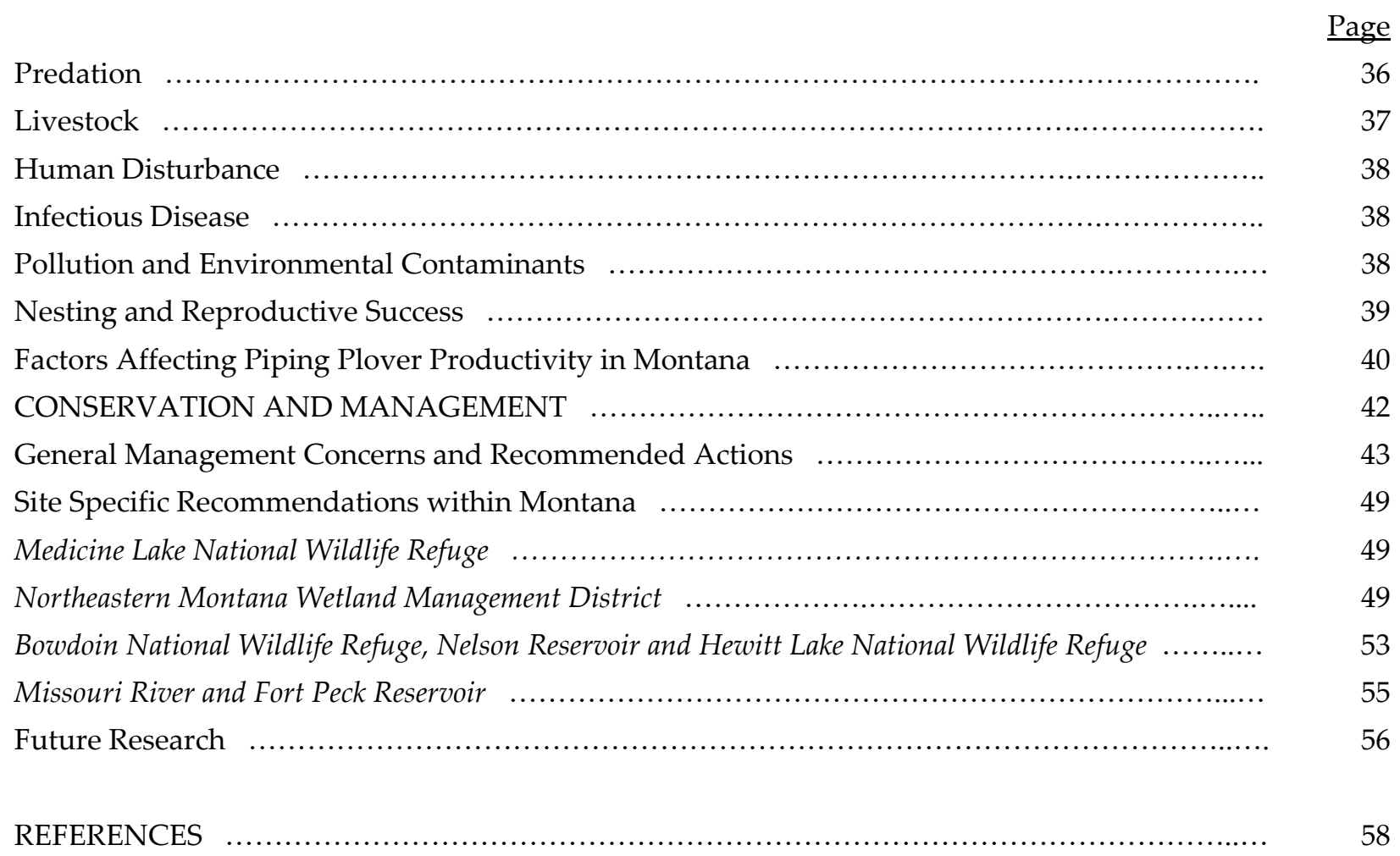




\section{LIST OF TABLES}

Table $1 \quad$ Habitat characteristics for Northern Great Plains piping plovers during the breeding season

Table 2 Land ownership within unit boundaries for critical piping plover habitat in Montana. Data in hectares and river kilometers or (acres and river miles).

Adapted from: USFWS, 2002

Table 3 Summary of 1991, 1996 and 2001 international piping plover breeding censuses in the Northern Great Plains. Adapted from: Haig et al 2005.

Table 4 Estimated numbers of adult piping plover in Montana based on annual survey results, 1988-2005. Data from unpublished reports prepared by:

The Nature Conservancy, USACE, and USFWS

Table 5 Estimated numbers of piping plover pairs in Montana based on annual survey results, 1988-2005. Data from unpublished reports prepared by: The Nature Conservancy, USACE, and USFWS

Table 6 Estimates of piping plover reproduction on Fort Peck Reservoir, 2002-2005.

Data from USACE, G. Pavelka, pers. comm.

Table 7 Estimates of piping plover reproduction on the Fort Peck River Reach of the Missouri River, 2002-2005. Data from USACE, G. Pavelka, pers. comm.

Table 8 Combined estimates of piping plover reproduction for Medicine Lake NWR and Northeast Montana WMD, 1996-2005. Data from USFWS, A. Ryba pers. comm..

Table 9 Causes of piping plover nest failures along the Missouri River, Montana, during USACE monitoring period 1993-2005. Includes Fort Peck Reservoir and Fort

Peck River Reach. Data from USACE, G. Pavelka, pers. comm. 


\section{LIST OF FIGURES}

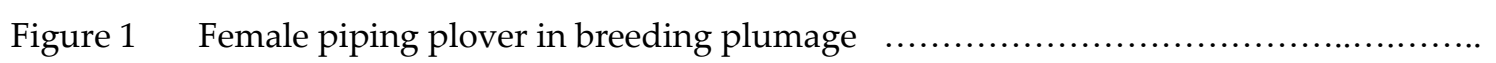

Figure 2 Distribution range of the piping plover in North America

Figure 3 Breeding distribution and abundance of piping plovers for North America in 2001. Adapted from: Ferland and Haig, 2002

Figure 4 Winter distribution and abundance of piping plovers in 2001. Adapted from:

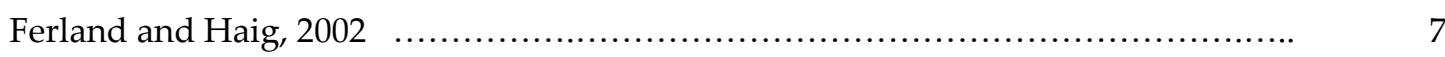

Figure $5 \quad$ Quarter latilong occurrences for piping plovers 1995-present $\quad$....................... 8

Figure 6 Distribution of piping plovers in Montana, based on 1985-2004 breeding Records. Adapted from: Montana Heritage Program $\quad$..............................

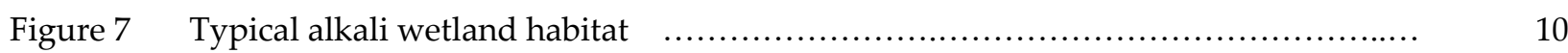

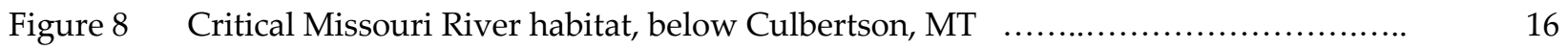

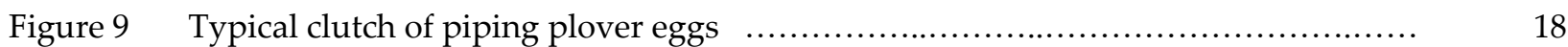

Figure 10 Numbers of breeding pairs and adults recorded in Montana, based on combined

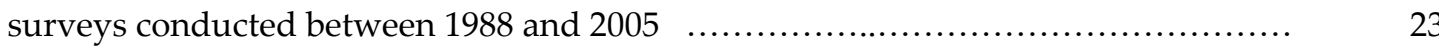

Figure 11 Distribution of adult piping plovers in Montana, based on combined survey

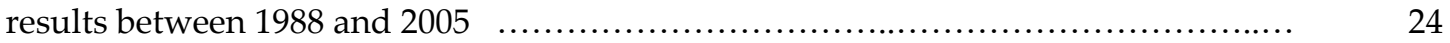

Figure 12 Distribution of adult piping plovers in Montana, based on combined ten-year trend survey results between 1996 and 2005 ......................................

Figure 13 Pre-regulation hydrograph for Missouri River, below Fort Peck Dam,

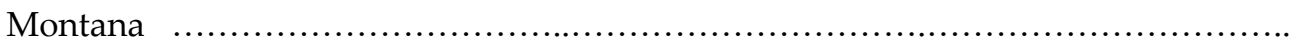

Figure 14 Post-regulation hydrograph of Missouri River, below Fort Peck Dam, Montana

Figure 15 Mean daily water temperature $\left({ }^{\circ} \mathrm{C}\right)$ for Missouri River mainstem locations in 2004

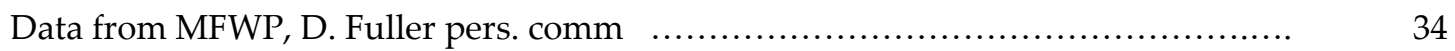

Figure 16 Exclosure protecting piping plover nest at alkali lake, North Dakota.................. 37

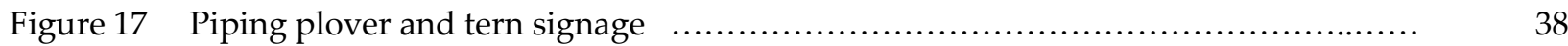

\section{LIST OF APPENDICES}

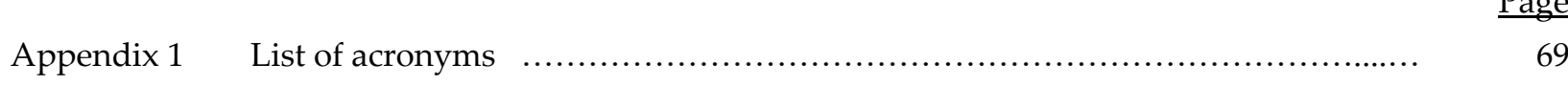

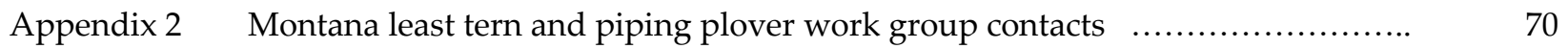

Appendix 3 Datasheet for annual piping plover breeding bird census in Montana ............ 71

$\begin{array}{lll}\text { Appendix } 4 \quad \text { International piping plover breeding census guidelines and datasheet } \quad \ldots . . . . . . . & 72\end{array}$

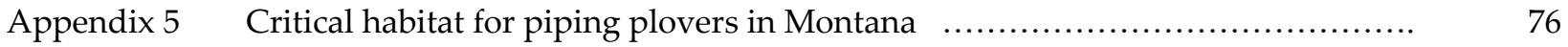




\section{INTRODUCTION}

The piping plover (Charadrius melodus) is a small, sand-colored, migratory shorebird that is listed as threatened or endangered throughout its range (USFWS 1985, USFWS 1988). Breeding adults most commonly nest on expansive sandy beaches from Newfoundland to South Carolina and along prairie rivers or alkali wetlands from central Canada to southern Nebraska (USFWF 1988, Haig 1992). Wintering grounds include the Atlantic and Gulf coasts of the southern U.S., northeastern Mexico and several islands in the Caribbean (Haig and Elliot-Smith 2004). In Montana, plovers nest on sparsely vegetated sand and gravel bars along the Missouri River as well as along the edges of alkali wetlands and sloughs in the northeastern part of the state.

Today, the species is imperiled throughout much of its range (USFWS 1988, Haig 1992, Ferland and Haig 2002, Haig and Elliot-Smith 2004) due primarily to increased predation, habitat alteration and human disturbance. In the interior U.S., housing and recreational development of beach habitat in the Great Lakes region as well as alteration of natural river flow dynamics in the Northern Great Plains has had a major impact on the reproductive success of piping plovers. Channelization and impoundment of prairie rivers to meet navigation and flood control objectives has altered natural flood water regimes, leading to flooding of nests, concentration of predators and a significant decline in habitat availability. In addition, wetland drainage, habitat alteration and increased predation pressures, all a result of human disturbance, have reduced productivity at alkaline wetland sites.

In 1985, piping plovers were federally listed under the U.S. Endangered Species Act (USFWS 1985). In the listing, three distinct breeding populations were identified: Atlantic coast and Northern Great Plains populations were listed as threatened while the Great Lakes birds were considered endangered (Plissner and Haig 2000). In fact, this species was, and still is, the only extant shorebird listed as an entire species under the U.S. Endangered Species Act (USFWS 1985, Ferland and Haig 2002).

Unlike many endangered species that have contiguous geographic ranges, piping plovers nest in many different habitats, each with a unique set of limiting factors (Brown 1986). As piping plover ecology and management requirements differ between locations, the USFWS appointed two recovery teams to facilitate recovery efforts over this wide geographic area. In 1988, the Great Lakes/Northern Great Plains Recovery Team developed a recovery plan that included management recommendations specific to inland populations (USFWS 1988) while the Atlantic Coast Recovery Team produced a plan for plovers along the East Coast (USFWS 1996). The following year, two regional Canadian recovery teams (Atlantic and Prairie) were established (Goossen et al 2002). Although the Great Lakes/Northern Great Plains Recovery Team was disbanded in 1996, partners, including many of the states in the Northern Great Plains, have continued to be involved in piping plover recovery. Teams from both the U.S. and Canada have also collaborated extensively on overall recovery efforts for the species during the past 20 years and the recent formation of the International Piping Plover Coordination Group will likely enhance conservation efforts.

The recovery plan for the Great Lakes and Northern Great Plains piping plover populations, hereinafter referred to as the piping plover recovery plan, (USFWS 1988), describes a number of actions necessary to 
achieve recovery of the inland birds, which if met, would allow delisting to be considered. Although the plan calls for essential breeding and winter habitat to be protected, it uses population goals as the primary criterion for recovery (USFWS 1988, Aron 2005). Delisting of the Northern Great Plains population will be considered when 1,300 pairs (2,600 birds) have been maintained in a specific distribution for 15 years, assuming at least three major censuses have been conducted during this period. Montana has a specific recovery goal of 60 pairs (120 birds).

As a state Montana provides a diverse array of habitats for breeding plovers. While the proportion of breeding birds recorded in Montana in recent years (7\% in 2001) has declined relative to states such as North Dakota, Montana has traditionally supported a sizable segment of the U.S. Northern Great Plains population (15\% in 1991). The peripheral nature of Montana relative to the overall breeding range of plovers, coupled with tremendous fluctuations in habitat availability between years at the landscape level, most likely influences the number of birds that arrive at breeding grounds in any given year. Given such fluctuation, we believe that Montana's wetlands and reaches of the Missouri provide a vital resource to piping plovers during years characterized by abnormal weather and water conditions elsewhere.

This plan describes the current status of the population and actions necessary to achieve and maintain the recovery goal for piping plovers breeding in the State of Montana. Experts in state and federal resource agencies were consulted to determine the status of Montana's current population and habitats as well as their potential for increase. Although plovers may be relatively faithful to a mosaic of breeding sites, if local conditions decline, birds respond by shifting sites. If habitat conditions remain poor, adults that move may not survive long enough to disperse back to their former sites (Haig et al 2005). In light of the species dispersal response, we believe that a ten-year trend period will provide flexibility in planning and management relative to plover biology.

The goal of this plan is to manage for and maintain approximately 60 breeding pairs of piping plovers, on a running ten-year average, distributed in appropriate habitats in Montana. The USFWS plans, however, to undertake a five-year status review beginning in September 2006. Should the status review lead to revision of the recovery plan, it is likely that current goals will be adjusted in the future. The goal set in this plan will, however, allow us to meet the standards of the current recovery plan while providing support for national recovery.

Moreover, in preparing this plan, Montana Department of Fish, Wildlife and Parks (MFWP) recognizes that an integrated multi-agency approach is required to manage this population effectively. As such, the plan attempts to compile into one document the measures required to enhance recovery, whether such actions are undertaken by the State or in collaboration with other agencies and/or tribal authorities. We believe that such an approach will ultimately strengthen the program by building on collaborative management activities already being undertaken. 


\section{TAXONOMY AND SYSTEMATICS}

Ornithologists have debated the taxonomic classification of the piping plover for over a century. Originally considered a race of the common ringed plover, Charadrius hiaticula, (Wilson and Bonaparte, no date), the piping plover was first described as a separate species by Ord in 1824. Revisions to the forth edition of the American Ornithological Union (AOU) Checklist resulted in the binomial, Aegialitis meloda, being changed to Charadrius melodus (Moser 1942). In addition to changes in the binomial, the acceptance of two subspecies, C. m. melodus (Atlantic birds) and C. m.circumcinctus (inland birds), has also been questioned. In fact, since Ord's designation of piping plovers as a species, the AOU has fluctuated between accepting and rejecting designation of inland and Atlantic subspecies (AOU 1886, 1957, Haig and Oring 1988a). While the first two editions of the AOU Checklist recognized both taxa (AOU 1886, 1895), such designation was omitted from the third and forth editions (Wilcox 1959). In 1942, Moser published data suggesting that the extent and brightness of breast bands distinguished inland and Atlantic breeders. These data, coupled with geographic distribution patterns, led the AOU to reinstate $C$. m. circumcinctus as a recognized subspecies (AOU 1945).

Wilcox (1959), however, considered the subspecies circumcinctus of dubious validity, noting the presence of a variety of breast band forms among piping plovers trapped on Long Island, New York. Subsequent morphological measurements also failed to detect any appreciable differences in wing and tail measurements of birds with different plumage types (Wilcox 1959). Moreover, early electrophoretic analyses detected little genetic difference between local or regional populations in Saskatchewan, Manitoba, North Dakota, Minnesota, and New Brunswick (Haig and Oring 1988a). In light of this genetics study, the AOU returned to the single species designation in 1998 (AOU 1998).

More recently, however, refined mitochondrial DNA analyses support subspecific designation (Haig and Elliot-Smith 2004). In particular, the Atlantic population appears reproductively isolated from the interior populations with the Great Lakes individuals aligning more closely with those on the Northern Great Plains and Canadian Prairies (Haig, pers. comm. quoted in Haig and Elliot-Smith 2004). While the U. S. Endangered Species Act identifies and protects endangered and threatened species, subspecies and populations, designations can "make or break" recovery of specific species because resources allocated to their recovery are often prioritized based on taxonomic status (Ryder 1986). Given recent contributions to conservation from the emerging field of molecular biology (Haig 1998) further research utilizing more sensitive genetic and molecular techniques may ultimately resolve this issue.

\section{SPECIES DESCRIPTION}

Weighing between 46-64 grams (1.5-2 ounces) and measuring $17 \mathrm{~cm}$ (7 in.) long with a wingspan of approximately $38 \mathrm{~cm}$ (15 in.), the piping plover is a small, relatively stocky migratory shorebird. Although males and females are similar in size, Wilcox (1959) found that breeding females were slightly heavier than males (55.6 g vs. $54.9 \mathrm{~g}$ ) and had slightly shorter tail lengths (50.5 mm vs. $51.3 \mathrm{~mm}$ ).

Piping plovers are one of six species of belted plovers, characterized by the presence of at least one breast band. The species' sand colored upper parts and white under sides are typical of its genus, but its short stout bill, large dark eyes isolated on a pale face and bright orange legs make it easy to distinguish from 
other belted plovers (Haig and Oring 1987, Sibley 2003). During the breeding season, a black bar develops across the forehead, from eye to eye, and the breast marking forms a single black band, which is often incomplete. Piping plovers do, however, exhibit slight breeding plumage dimorphism. The black breast band and brow bar are typically more pronounced in breeding males (see front cover) than females (Figure 1), allowing the sexes to be accurately identified in approximately 95\% of cases (Wilcox 1959).

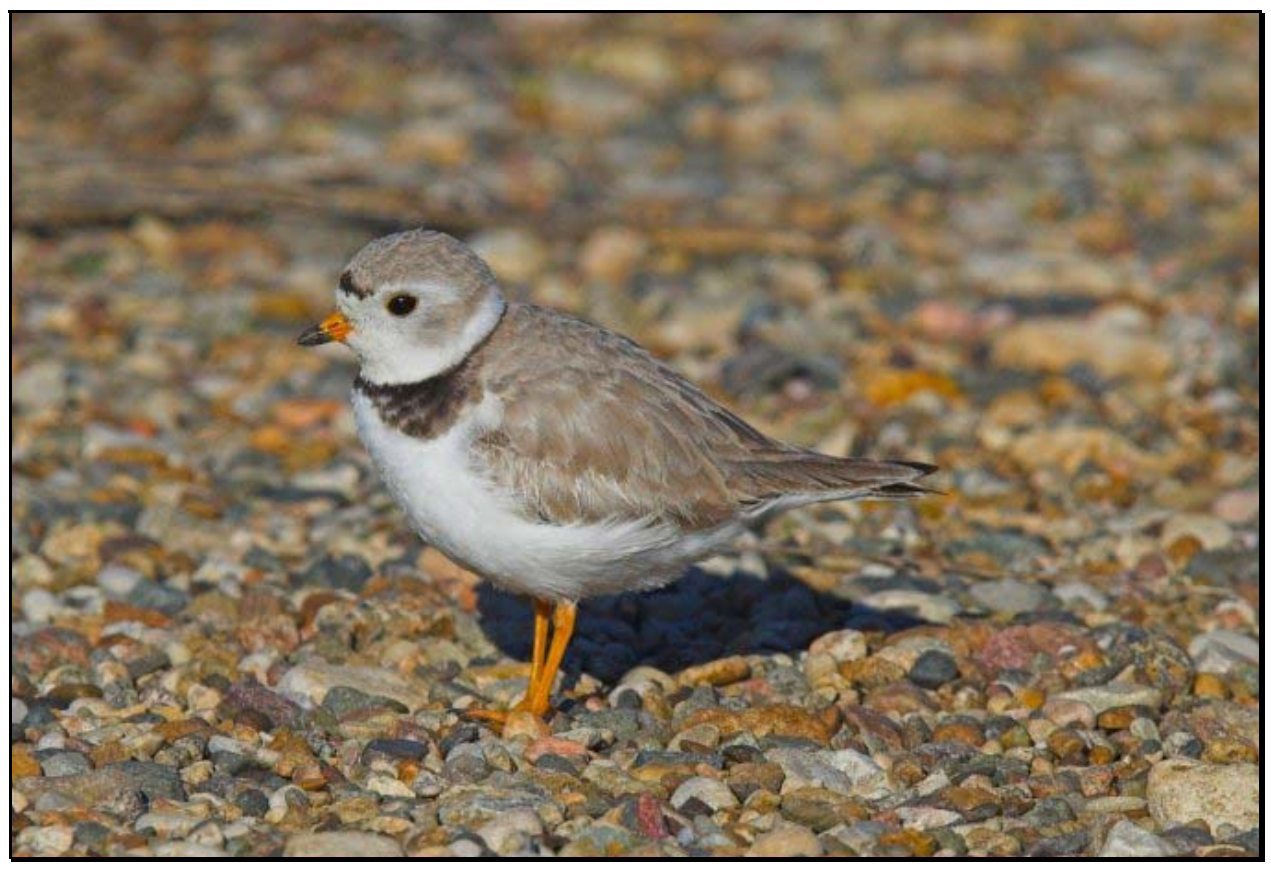

Figure 1: Female piping plover in breeding plumage Photo courtesy: Doug Backlund, Pierre, S.D.

In winter, piping plovers lose their black bands, the legs fade from orange to pale yellow, and the bill becomes mostly black. Immature plumage resembles adult non-breeding plumage; juveniles acquire adult plumage the spring after they fledge.

Piping plovers earned both their common and scientific names from their melodious call notes. In fact, the call, a distinctive "peep, peep, peep-lo" sound, is often heard before the bird is seen. From a diagnostic perspective, therefore, the high pitched call of the piping plover, coupled with morphological characteristics such as a single black neck band (present during the breeding season), short stout bill and bright orange legs makes it readily identifiable and unlikely to be confused with other small plovers such as the snowy plover (Charadrius alexandrinus) and the collared plover (Charadrius collaris). 


\section{HISTORICAL AND CURRENT DISTRIBUTION}

\section{Breeding Range}

Endemic to North America, the piping plover is a migratory species that breeds in three disjunct geographic regions: the Northern Great Plains, the Great Lakes and Atlantic coast of North America (Figure 2). Although the current boundaries of the breeding range are similar to boundaries in the early 1900s (Haig and Oring 1985, Haig and Oring 1987, Haig and Oring 1988b), the distribution of plovers is now much more fragmented (Figure 3).

Breeding birds have been extirpated from Illinois, Indiana, Ohio, Pennsylvania and New Hampshire, presumably as a result of human disturbance and habitat destruction (Russel 1983, Haig and Oring 1988b, Prindiville-Gaines and Ryan 1988). In addition, inland populations, occurring at low densities in patchily distributed habitats (Ryan et al 1993), are more isolated from one another (Haig and Oring 1985). Consequently, the species breeding range represents remnants of a wider distribution that existed prior to anthropogenic alteration of essential plover habitat.

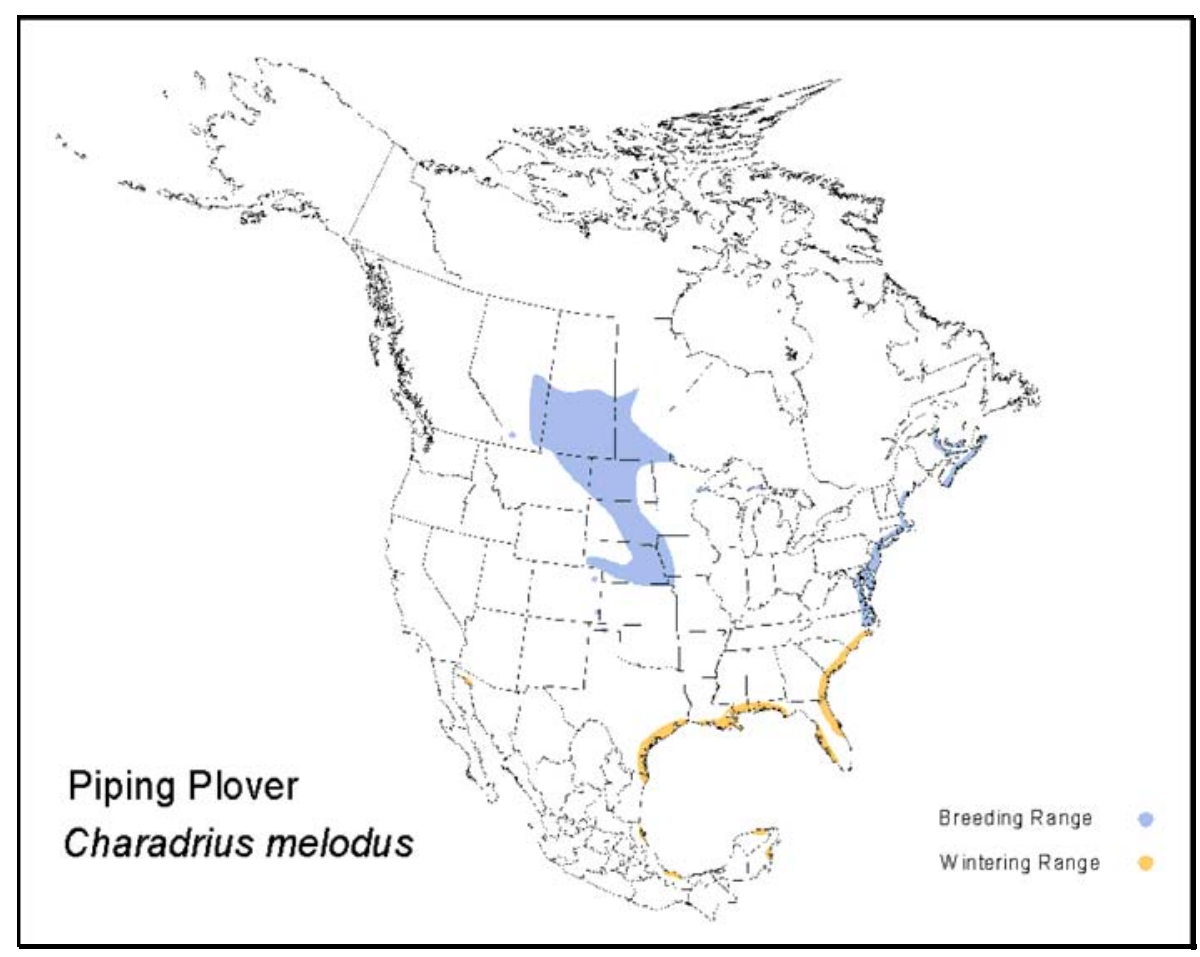

Figure 2: Distribution range of the piping plover in North America From: Mitchell et al 2000.

Historically, the Great Lakes population nested throughout much of the Great Lakes region in the northcentral U.S. and in south-central Canada (USFWS 2002). Although their numbers have increased over the past decade, these birds are restricted to several sandy beaches on Lakes Superior, Michigan and Huron in northern Michigan and Wisconsin (Ferland and Haig 2002, Haig et al 2005). Along the Atlantic seaboard, populations nest on expansive sandy beaches from Newfoundland, southeastern Quebec, and New Brunswick to North Carolina (Haig 1992, USFWS 2002, Haig and Elliot-Smith 2004). 


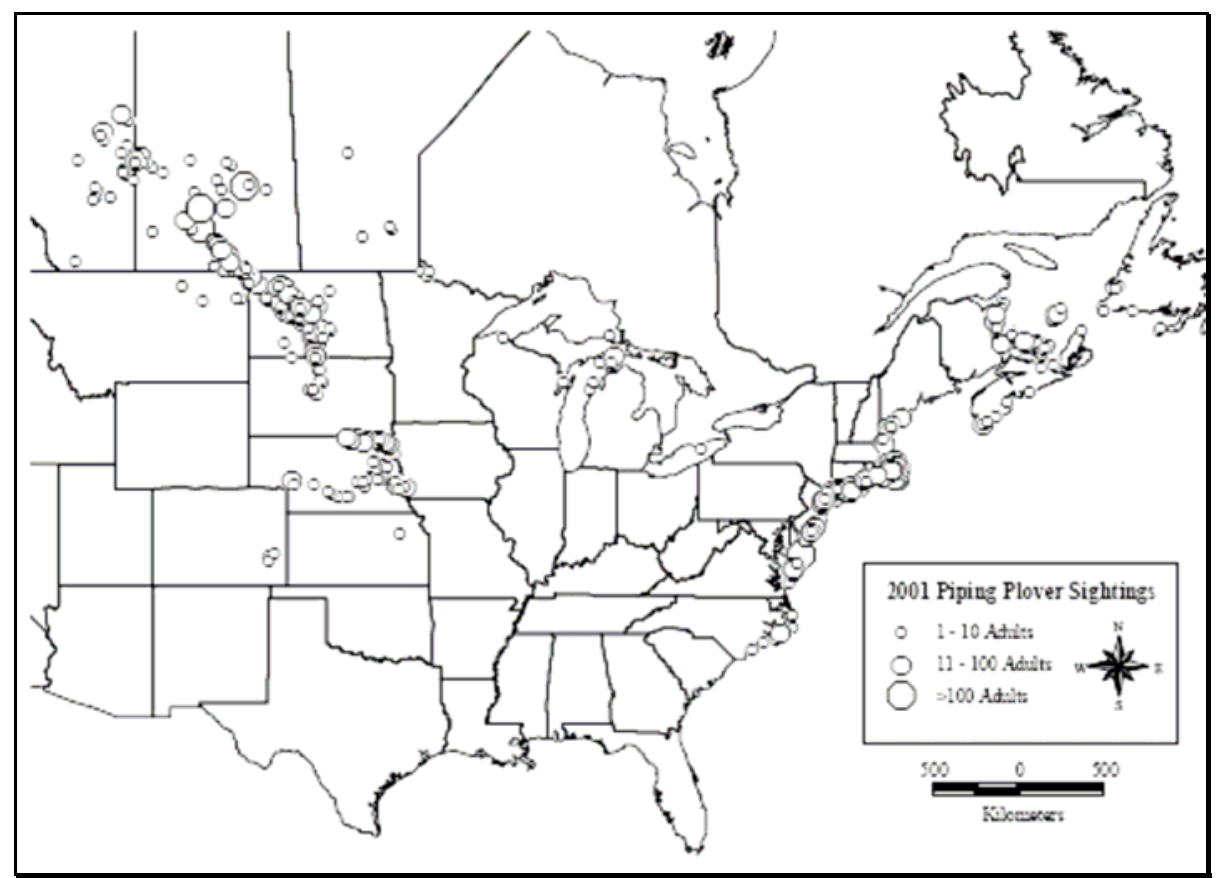

Figure 3: Breeding distribution and abundance of piping plovers for North America in 2001 Adapted from: Ferland and Haig, 2002.

The breeding range of the Northern Great Plains population traverses Alberta, southern Saskatchewan, and southern Manitoba extending southeastward into eastern Montana, North Dakota, South Dakota, Minnesota, Nebraska and Iowa (USFWS 2002). Oklahoma represents the extreme southern limit of the birds breeding distribution on the Northern Great Plains, while Lake Athabasca in southern Saskatchewan is the northernmost (Adam 1984, Goossen et al 2002). In addition, a small population exists in Colorado and Kansas (Ferland and Haig 2002).

Although the breeding range is extensive, the majority of breeding pairs in the U.S. portion of the population's range are in North Dakota, Montana, South Dakota and Nebraska (National Research Council 2004). The current breeding range encompasses alkali lakes and wetlands in southern Canada, northeastern Montana and northwestern North Dakota, and extends south along major prairie river systems, such as the Missouri, Niobrara and Platte (Haig and Elliot-Smith 2004).

\section{Winter Range}

From a conservation perspective, winter censuses provide an opportunity to relocate banded birds and document connectivity of breeding populations in winter (Haig et al 2005). Based on sightings of colorbanded birds, results from three international censuses (conducted in 1991, 1996 and 2001) as well as data from Haig and Oring (1988b) suggest that most prairie and Northern Great Plains birds winter in the Gulf of Mexico, while the majority of Atlantic birds are seen further south on the Atlantic coast or the Caribbean (Haig et al 2005). 
As fewer than $65 \%$ of all breeding birds have been accounted for during range-wide winter censuses, the wintering range of piping plovers has yet to be clearly delineated (Ferland and Haig 2002, Haig et al 2005). Most birds appear, however, to winter along the Atlantic and Gulf coasts from North Carolina to Mexico and into the Bahamas and West Indies (Haig and Oring 1987, Haig and Oring 1988b, Hoopes et al 1989, Haig et al 2005) (Figure 4).

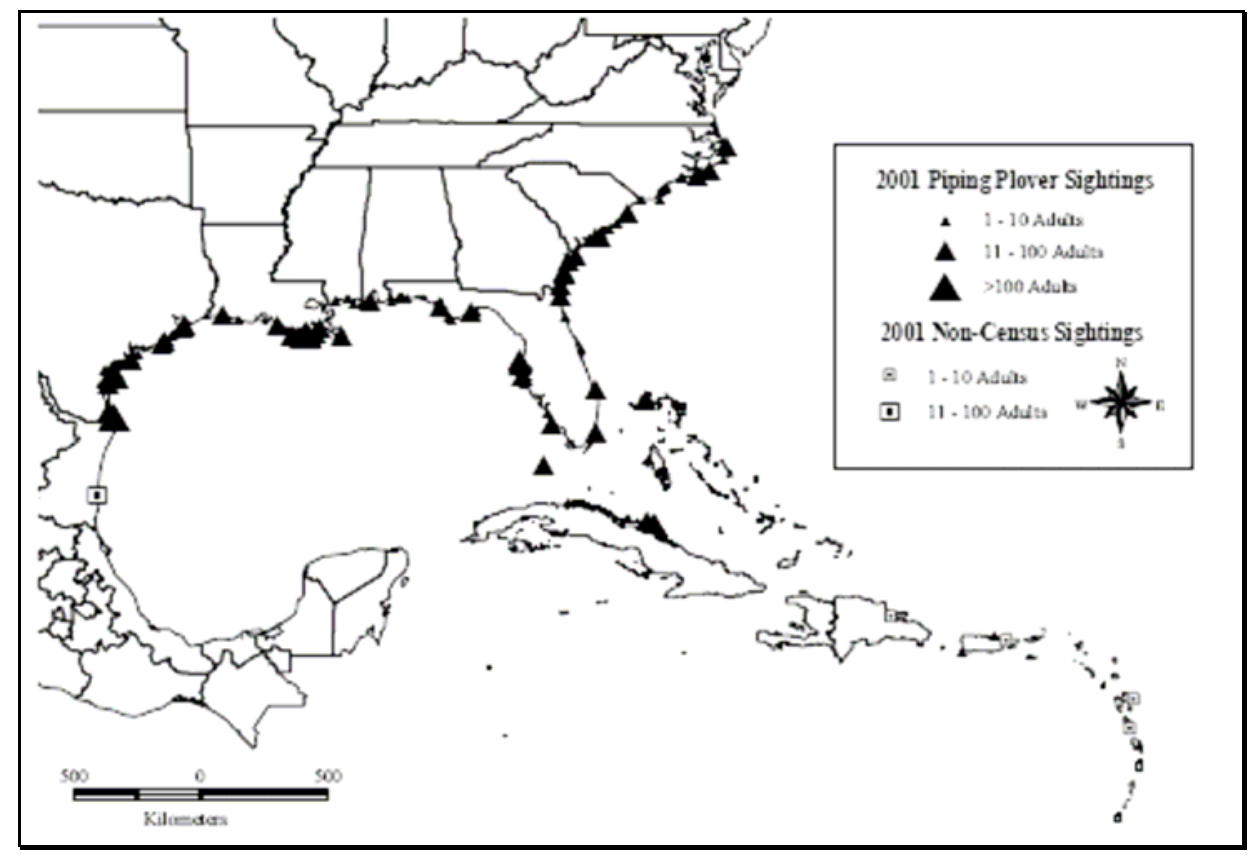

Figure 4: Winter distribution and abundance of piping plovers in 2001 Adapted from: Ferland and Haig, 2002.

Winter surveys conducted by Nicholls and Baldassarre (1990a) indicate that along the Gulf coast, Texas and Louisiana support the highest number of piping plovers per kilometer. A considerably smaller population winters along the shores of the Atlantic Ocean (Haig and Plissner 1993). For the Atlantic coast region, the greatest densities of over-wintering plovers were recorded in Georgia and South Carolina. More specifically, the barrier islands off Georgia and South Carolina appear to host the largest numbers of wintering birds for the region although a few sites in North Carolina and Florida also have relatively high numbers.

Plovers wintering along the Atlantic coastline are generally distributed in small groups: averages of six piping plovers per site were noted during Nicholls' 1986-87 survey (Nicholls 1989). Given the extensive survey coverage, coupled with the relatively small group sizes recorded, Nicholls and Baldessarre (1990a) speculate that a large proportion of the North American breeding population probably winters throughout the Caribbean islands. 


\section{Distribution in Montana}

Historic records of piping plovers in Montana are rare (Carlson and Skaar 1976). Bent (1929) does not specifically list Montana within the breeding range of the piping plover, but does note "many gaps in the range". Early accounts recorded piping plovers in South Dakota (Miner County), North Dakota (Kenmare), and Big Stick Lake in southern Saskatchewan (Bent 1929): such a distribution pattern indicates that plovers may well have occupied similar habitats within northeastern Montana.

Plovers were first recorded in Montana in 1967 in Phillips County (Prellwitz et al 1989) and were observed in Sheridan and Valley Counties during the 1970s (Carlson and Skaar 1976). Although they were known to breed at Bowdoin National Wildlife Refuge (NWR) and at Fort Peck Reservoir (Skaar et al 1985), little attention was paid to the species prior to its listing in 1985. As a result, few observations prior to 1985 are recorded (Montana Bird Distribution Database 2005). More recently, the majority of breeding sites have been reported in three distinct areas in Montana: the extreme northeastern portion of the state (Northeast Montana Wetland Management District), Nelson Reservoir and Bowdoin NWR, and along the Missouri River including Fort Peck Reservoir (Figure 5).

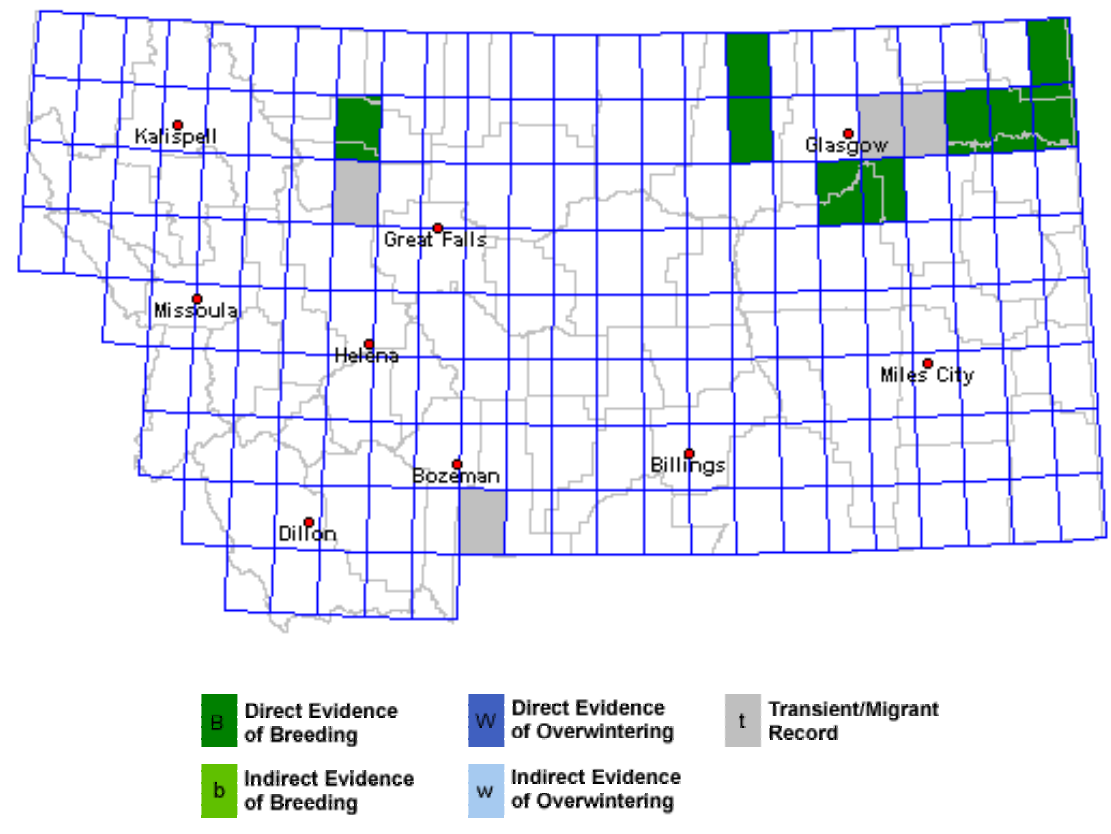

Figure 5: Quarter latilong occurrences for piping plovers, 1995-present.

Courtesy: Montana Bird Distribution Database, Natural Heritage Program, 2005.

Breeding sites at Fort Peck Reservoir occur above the west end of the dam and along the shorelines of the Big Dry Arm. Along the Missouri River, below Fort Peck, the majority of sandbars used by plovers are situated downstream of the Milk River confluence (USACE 1997). Plovers have also sporadically reproduced at Alkali Lake in Pondera County, which is the extreme western edge of their U.S. distribution. A detailed distribution map compiled from breeding observations, gathered between 1988 and 2004, is presented in Figure 6. Observational records of transient or migrant birds have also been 
reported near Helena at Canyon Ferry Reservoir (Bergeron et al 1992) as well as northwest of Great Falls at Freezeout Lake (Montana Bird Distribution Database 2005) and north of Malta at Whitewater Lake (Fritz Prellwitz, pers. comm.). There are no winter records in Montana.

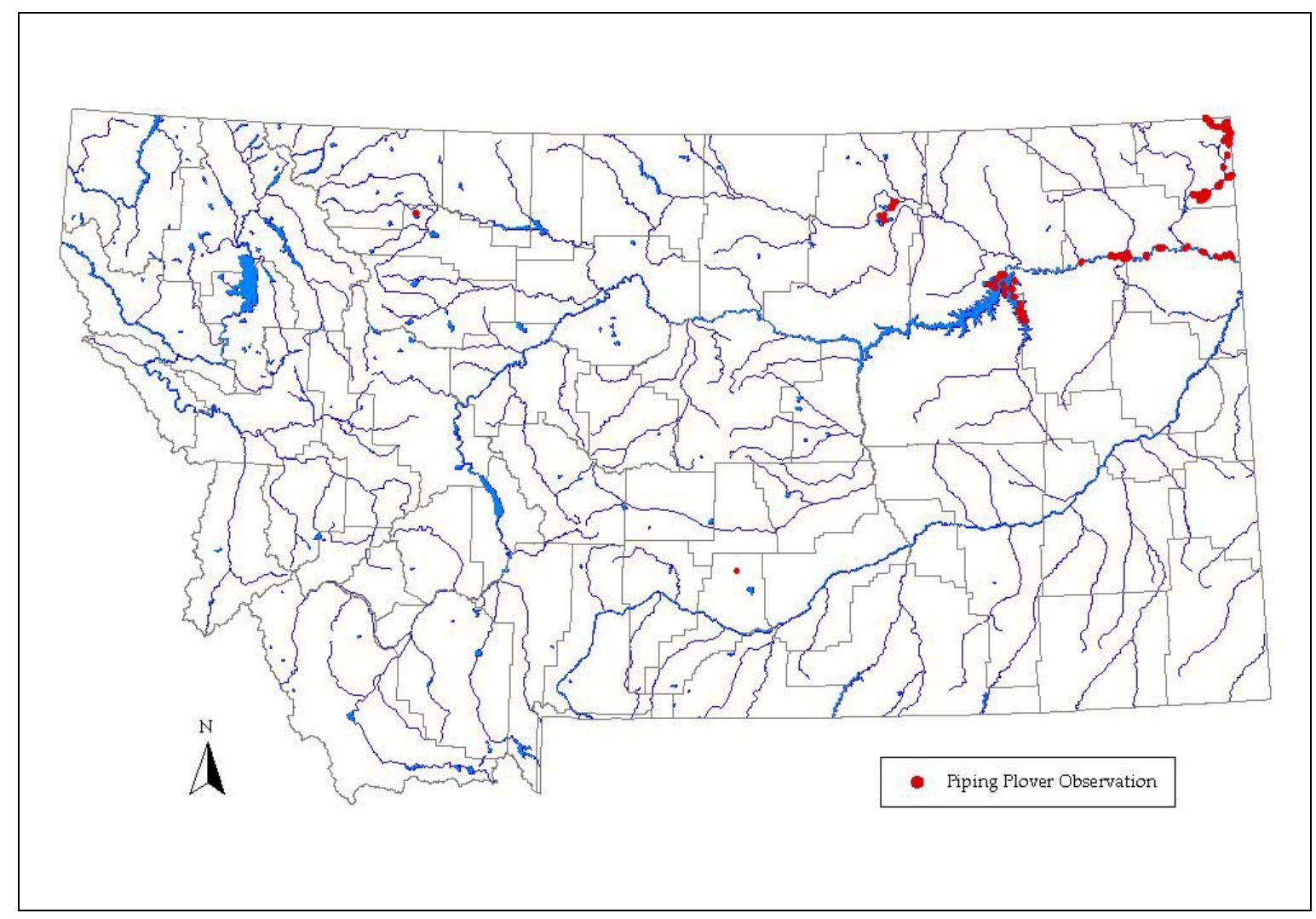

Figure 6: Distribution of piping plovers in Montana, based on 1985-2004 observational records. Adapted from: Montana Heritage Program.

\section{HABITAT REQUIREMENTS}

\section{Breeding Season Habitat}

In north-central North America, plovers typically nest on barren sand and gravel beaches along the Great Lakes, and on alkali flats, gravel shorelines and river sandbars in the Great Plains (USFWS 2002). While data suggests that habitat use by plovers is dynamic (USFWS 2002), alkali lakes and wetlands associated with the Missouri Coteau landform, located inside the Prairie Pothole Region, appear to support a significant portion (34-75\%) of the Great Plains population in any given year (Haig and Plissner 1993, Murphy et al 2000, Plissner and Haig 2000, Haig et al 2005, Skagen and Thompson 2005). Remaining nest sites occur primarily along rivers and reservoirs although fresh water lakes, dry alkali lakes, sandpits, industrial ponds and gravel mines may also be utilized (Haig et al 2005).

Studies on the specific habitat requirements of the piping plover across its breeding range have been few (National Research Council 2004) and quantitative data on habitat characteristics remains scarce (USFWS 
2002). Several studies suggest, however, that important physical attributes at the nest site include: presence of suitable nesting substrate, lack of vegetative cover, existence of favorable water conditions and availability of suitable forage habitat (Prindiville-Gaines and Ryan 1988, Schwalbach 1988, Ziewart et al 1992, Corn and Ambruster 1993, Licht 2001). While factors that contribute to optimal habitat conditions appear similar across habitat types, research suggests that specific requirements may differ. For example, although preferred vegetation cover is generally low for all sites, percentage cover varies considerably according to habitat type (Table 1). Moreover, as apparently suitable nesting habitat is not always utilized (Haig et al 2005), other factors, such as forage availability or disturbance, may ultimately affect nest site choice.

\section{Alkali Wetland Habitat}

In Montana, as well as throughout the Northern Great Plains, permanent, to seasonally flooded, alkaline sloughs (or potholes) embedded within the Prairie Pothole Region are utilized by breeding birds (Figure 7). These wetland habitats are typically closed basin depressions that receive water through surface precipitation, basin runoff, and seepage inflow of ground water (Sloan 1972). While the surrounding habitat may include pasture or rangeland composed of short grass prairie, nest sites are typically placed on dry salt flats or gravel beaches (USFWS 1994).

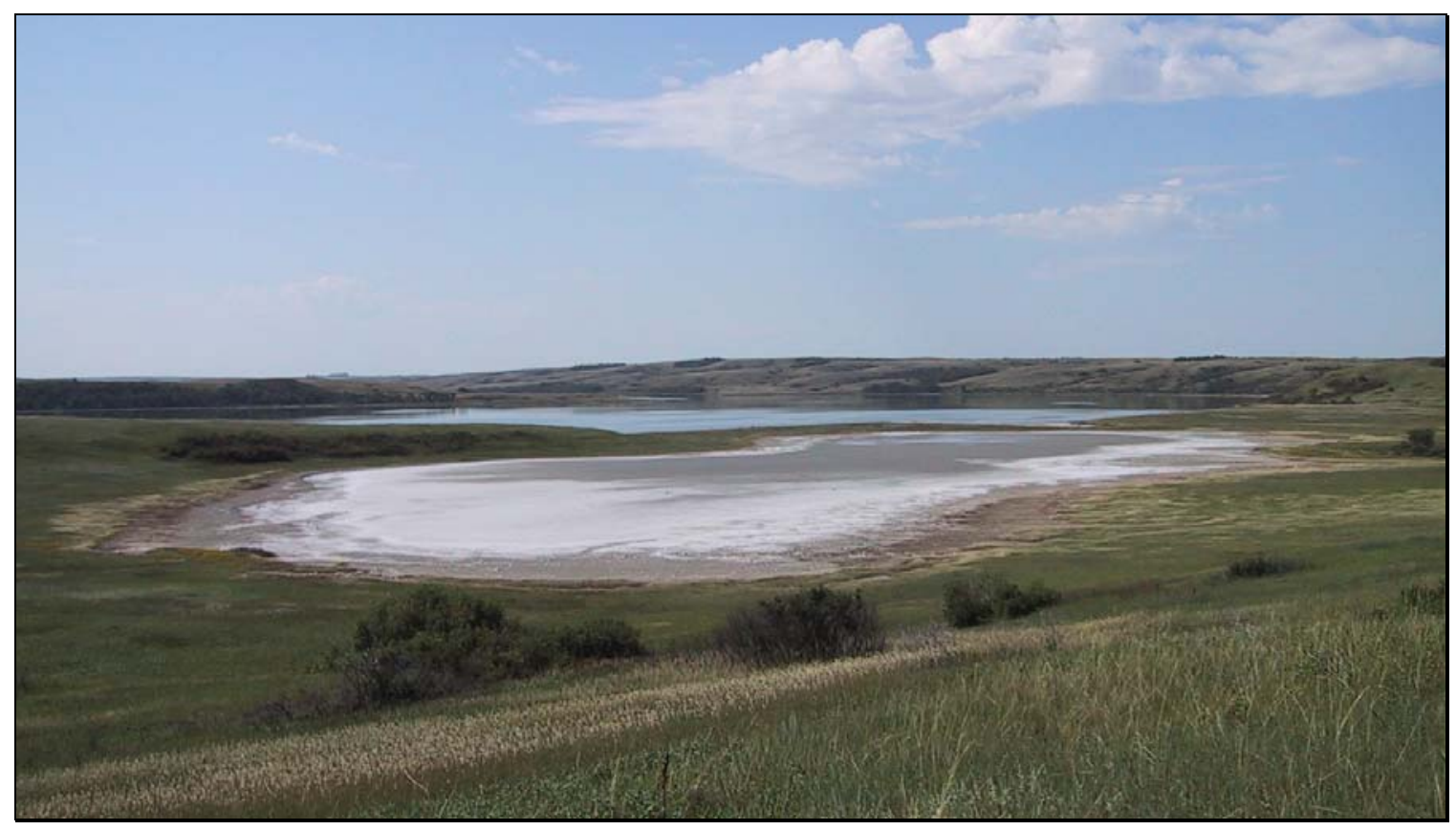

Figure 7: Typical alkali wetland habitat. Photo Courtesy: Adam Ryba.

The Great Plains region has a notoriously extreme and variable climate (Johnson et al 2004) and local and regional availability of alkaline beach habitats varies between years in response to changing basin levels and vegetation conditions (Licht 2001). In fact, dramatic fluctuations in water levels are commonplace, making such habitats highly unpredictable in space and time (Skagen and Thompson 2005). During drier climatic periods, substantial quantities of sparsely vegetated lower elevation beach habitat are available for breeding plovers. During wet periods, however, basin levels tend to be relatively high and only the 
highest elevation beach habitat is available (Licht 2001, Root and Ryan 2004). Thus, due in large part to the dynamic nature of these wetlands, birds tend to be opportunistic and dispersed across the landscape.

Sites with gravel substrate appear to provide the most suitable sites for nesting. In North Dakota, gravel was more evenly distributed and in greater concentration on piping plover territories than at unoccupied sites and eggs were more likely to hatch than those on alkali substrate (Prindiville-Gaines and Ryan 1988). Similarly, Whyte (1985) demonstrated that breeding birds were more likely to establish nests on gravel than predicted by chance. Research conducted by Espie et al (1996) corroborates this, indicating that birds prefer nesting on gravel beaches than those with lower gravel content.

Although data suggests that the amount and distribution of vegetation affects piping plover habitat selection and reproductive success (USFWS 1994), research conducted by Prindiville-Gaines and Ryan (1988) at alkali wetlands in North Dakota failed to detect any difference in vegetation cover between nesting territories and unoccupied sites. The authors did note, however, that vegetation had a more clumped distribution on territories, compared to unoccupied sites, resulting in large areas of unvegetated beach habitat. Moreover, successful breeding territories typically had either less vegetation or more clumped vegetation than those with unsuccessful nests. Combining nesting territory descriptions as well as nest site photographs from several research efforts at alkali wetlands, Root and Ryan (2004) have recently determined that unvegetated beaches, or sparsely vegetated beaches dominated by forbs, have greater numbers of nests than those dominated by grasses. As most forbs typically only attain a height of several centimeters during the nesting season it is possible that these sites are preferentially selected (Root and Ryan 2004) as they do not limit the plover's ability to detect nest predators (Haig 1992).

In addition to vegetation cover and substrate type, along the shorelines of inland lakes and saline wetlands plovers appear to prefer wide beaches for nesting. At Chain-of-Lakes in North Dakota, Prindiville-Gaines and Ryan (1988) reported that piping plovers established territories on beaches $>25 \mathrm{~m}$ wide. Mean beach width was also greater at occupied sites and the authors speculate that below a threshold beach width $(>20 \mathrm{~m})$ the probability of nest detection by predators may increase abruptly.

\section{Riverine Habitat}

Characteristic riverine nesting sites include reservoir beaches and large dry, barren sand or gravel bars within wide, unobstructed river channels (USFWS 1988). Nests are usually located after the spring and early summer flows recede and dry areas on sandbars are exposed. Along the Platte River, Nebraska, relatively large sandbars, averaging $286 \mathrm{~m}$ long and $55 \mathrm{~m}$ wide, appear to be selected when available (Faanes 1983). In addition, preferred vegetative cover at nest sites is generally low (Schwalbach 1988). Although Faanes (1983) reported vegetative cover of $25 \%$ on nesting sandbar habitat along the Platte River, other research suggests that the optimum range is much lower: estimates range from $0-10 \%$ (Armbruster 1986). Likewise, along the Missouri River in South Dakota, plover colony sites were characteristically barren or with short $(<10 \mathrm{~cm})$ sparse $(<10 \%)$ vegetative cover (Schwalbach 1988). 
Table 1: Habitat characteristics for Northern Great Plains piping plovers during the breeding season.

\begin{tabular}{|c|c|c|c|}
\hline Habitat & $\begin{array}{l}\text { Habitat } \\
\text { Measurement }\end{array}$ & $\begin{array}{l}\text { Optimal Habitat } \\
\text { Characteristics }\end{array}$ & Reference \\
\hline \multicolumn{4}{|l|}{ Alkali lake/wetland } \\
\hline Mean beach width & $25 \mathrm{~m}$ & $>20 \mathrm{~m}$ & $\begin{array}{l}\text { Prindiville-Gaines } \\
\text { and Ryan (1988) }\end{array}$ \\
\hline Vegetation & $\begin{array}{l}{ }^{1} \text { sparse or clumped } \\
\text { vegetation; }{ }^{2} \text { forbs } \\
\text { preferred to grass }\end{array}$ & $\begin{array}{l}\text { barren to sparsely vegetated } \\
\text { or clumped distribution; } \\
\text { shorter vegetation (forbs) }\end{array}$ & $\begin{array}{l}\text { 1Prindiville-Gaines } \\
\text { and Ryan (1988); } \\
{ }^{2} \text { Root and Ryan } \\
\text { (2004) }\end{array}$ \\
\hline Substrate & $\begin{array}{l}{ }^{1} \text { mixed gravel and } \\
\text { sand; }{ }^{2} \text { gravel } \\
\text { versus alkali }\end{array}$ & $\begin{array}{l}{ }^{1} \text { homogenous substrate at } \\
\text { nest site - primarily gravel; } \\
{ }^{2} \text { heterogenous at larger scale }\end{array}$ & $\begin{array}{l}{ }^{1} \text { Cairnes (1977) } \\
\text { 2Prindiville-Gaines } \\
\text { and Ryan (1988) }\end{array}$ \\
\hline \multicolumn{4}{|l|}{ Riverine } \\
\hline Mean channel width & 295-430 meters & wide (>300 meters) & Ziewitz et al (1992) \\
\hline Mean sandbar area & $0.48-1.90$ hectares & $\begin{array}{l}\text { variable from } 0.20-4.04 \\
\text { hectares, preferably large }\end{array}$ & Ziewitz et al (1992) \\
\hline $\begin{array}{l}\text { Elevation (clearance } \\
\text { from water to nest) }\end{array}$ & 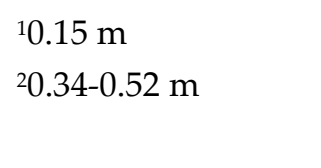 & $\begin{array}{l}\text { low ephemeral sandbars, } \\
\text { high enough to provide dry } \\
\text { bare ground during nesting }\end{array}$ & $\begin{array}{l}{ }^{1} \text { Schwalbach (1988) } \\
{ }^{2} \text { Ziewitz et al (1992) }\end{array}$ \\
\hline Vegetation & $1<10 \% ; \quad 225 \%$ & $\begin{array}{l}\text { barren to sparsely vegetated; } \\
\text { vegetation height short }\end{array}$ & $\begin{array}{l}\text { Schwalbach (1988) } \\
{ }^{2} \text { Faanes (1983) }\end{array}$ \\
\hline Substrate & gravel & gravel substrate & Ziewitz et al (1992) \\
\hline Forage site & $\begin{array}{l}\text { moist sandy } \\
\text { substrate }\end{array}$ & expanse of moist substrate & $\begin{array}{l}\text { Corn and Armbruster } \\
(1983)\end{array}$ \\
\hline \multicolumn{4}{|l|}{ Artificial Sandpit } \\
\hline Forage site & $<1.3 \mathrm{~km}(<1$ mile $)$ & $\begin{array}{l}\text { adequate prey base relatively } \\
\text { close to nest site }\end{array}$ & $\begin{array}{l}\text { Corn and Armbruster } \\
\text { (1983) }\end{array}$ \\
\hline Total surface area & $\begin{array}{l}0.6-79.6 \text { hectares } \\
(\text { mean }=20.6)\end{array}$ & $\begin{array}{l}\text { variable - nesting depends on } \\
\text { availability of natural } \\
\text { sandbar habitat }\end{array}$ & $\begin{array}{l}\text { Sidle and Kircsh } \\
\text { (1993) }\end{array}$ \\
\hline
\end{tabular}


Variables such as channel width and nest elevation above river reach also appear to play a role in nest selection (Schwalbach 1988, Ziewitz et al 1992). Research conducted by Schwalbach (1988) showed that, on average, plover nests were located $0.19 \mathrm{~m}$ above river reach range. Along the Platte River, however, nests were situated at slightly higher elevations (Ziewitz et al 1992). While data gathered in these studies preclude comparisons between habitat characteristics and reproductive success, the variables suggest that piping plovers preferentially select nest sites that provide wide horizontal visibility, protection from terrestrial predators and sufficient protection from rising waters (Schwalbach 1988, Ziewitz et al 1992, USFWS 2003).

\section{Foraging Habitat}

Along prairie rivers, piping plovers are often found in close association with interior least terns (Sterna antillarum). As such they are often thought to have similar habitat requirements. Despite similarities in nesting habitat along rivers, these closely related species belong to different feeding guilds: piping plovers feed on benthic invertebrates found along the moist sand shoreline while least terns are primarily shallow water piscivores. So, in addition to dry unconsolidated substrate for nesting and raising young, piping plovers tend to require adjacent moist sandy habitat for foraging (Corn and Armbruster 1983).

As habitat that meets both the nesting and foraging requirements is essential, not all potential sites are suitable. Primary foraging habitat includes open, moist, sandy sites on river systems as well as throughout most of the birds nesting range. Plovers feed by pecking at or just below the substrate surface (Caines 1977, USFWS 2002, Haig and Elliot-Smith 2004) and require feeding grounds that are rich in surface invertebrates (Shaffer and Laporte 1994). While adults typically concentrate feeding efforts within $5 \mathrm{~m}$ of the water's edge (Whyte 1985), chicks tend to feed on firmer ground at greater distances from the shoreline (Caines 1977).

Although plovers commonly forage near the water's edge, in North Dakota birds spent $42 \%$ of their time foraging along the shoreline and 45\% foraging at upland gravel sites (Beckerman 1988, Haig and ElliotSmith 2004). While moist substrate habitats are extremely valuable to piping plovers, these habitats must be juxtaposed with other key elements. For example, Elias et al (2000) showed that on beach segments along the Atlantic coast lacking ephemeral pools and bay tidal flats, wrack and open vegetation can be important, not only as a forage habitat but because they provide escape cover and roosting habitat. Likewise, adults and chicks in New Jersey exhibited flexibility in their choice of foraging habitat but generally selected areas with few people (Burger 1994). Thus, the need for habitat heterogeneity surrounding the nest site, particularly in more disturbed areas, may be an important factor in habitat selection (Nicholls and Baldassarre 1990b, Elias et al 2000).

\section{Artificial Nesting Habitat}

Piping plovers clearly have little flexibility when choosing nest sites (Goossen et al 2002). Preferred sandbar habitat has disappeared along many river segments in the interior U.S. and as a result plovers

have been forced to exploit new areas for nesting (Sidle and Kirsch 1993). Breeding birds now nest on artificially created habitat such as sand and gravel pits and islands created by dredging operations (USFWS 2002). Evidence suggests that plovers utilize artificial habitats when natural habitat is limiting, however, it is unclear to what extent they have replaced natural habitats or whether reproductive success 
is similar between habitats (Sidle and Kirsch 1993). While artificial sandbar creation has provided nesting habitat, from a cost-benefit perspective, such measures are expensive and tend to be temporary in nature, eventually eroding due to run-off. Further, these areas are only suitable for a limited period of time after their initial creation as vegetation encroachment generally reduces habitat quality after a few years.

More importantly, however, research has shown that many of these sites fail to provide an adequate forage base (Corn and Armbruster 1983). Compared to river channel sites, soil moisture, and consequently invertebrate density, is lower at sandpit sites. In fact, in some areas, plovers fly more than a kilometer between sandpit nest site and river channel foraging location. In addition, because sandpit sites are not isolated on islands, nests are more vulnerable to predation (National Research Council 2004). Thus, these artificially created sites may provide marginal nesting and forage habitat to breeding birds (Corn and Armbruster 1983).

\section{Migratory and Winter Habitats}

Piping plover winter habitat includes beaches, mudflats, and sandflats, as well as barrier island beaches and spoil islands (Haig and Oring 1985, Haig 1992). Birds have also been seen on ocean beaches and sand or algal flats in protected bays (Wilkinson and Spinks 1994, Drake et al 2001). Drake et al (2001) determined that habitat use varied seasonally along the Texas coastline: plovers used algal flats more during fall and spring than during winter whereas exposed mudflats were selected more frequently during winter.

Between 1986 and 1988, both the distribution and habitat characteristics of plovers during the winter were studied along the Gulf and Atlantic coastlines (Nicholls and Baldassarre 1990a, 1990b). Analysis of habitat variables along the Gulf Coast showed that plover sites were characterized by greater beach width and greater percentage mudflats than non-plover sites (Nicholls and Baldassarre 1990b). Along the Atlantic, however, piping plovers were most often found foraging in areas adjacent to large inlets and passes. In fact, the variation between sites led Nicholls and Baldassarre (1990b) to surmise that piping plover winter distribution may be correlated more with environmental heterogeneity than specific habitat features. Despite the difficulties encountered in developing predictive models based exclusively on habitat variables, the authors speculate that sandflats and sandy mudflats may attract the largest concentrations of piping plovers because of prey abundance and/or because the substrate coloration provides protection from aerial predators due to chromatic matching (Graul 1973, Nicholls and Baldassarre 1990b).

\section{CRITICAL HABITAT}

In 2002, the USFWS officially designated critical habitat for the Northern Great Plains breeding population (USFWS 2002). Under the Endangered Species Act, critical habitat refers to specific geographic locations that contain features essential for conserving a species and may require special management considerations. While critical habitat can be, and is, designated on private lands, it only relates to those activities on private lands that require federal permits or funding that are required to be reviewed under the Act. 
In determining which areas to propose as critical habitat for piping plovers, the USFWS (2002) considered both the physical and biological features (primary constituent elements) that were essential to conservation of the species. For piping plovers these included components essential for courtship, breeding, sheltering, brood-rearing, foraging, roosting, intraspecific communication and migration. Furthermore, it stated that the one overriding primary biological element that must be present at all sites is the maintenance of the dynamic ecological processes that create and maintain piping plover habitat.

On prairie alkali lakes and wetlands the physical primary constituent elements include shallow, seasonally to permanently flooded, wetlands with sandy to gravelly, sparsely vegetated beaches as well as springs and fens along the edges of alkali lakes and wetlands. Along rivers, sparsely vegetated channel sandbars, sand and gravel beaches on islands and temporary pools on sandbars are considered primary. At reservoirs and inland lakes such elements include sparsely vegetated shoreline beaches, peninsulas, islands composed of sand and gravel or shale and their interface with the water bodies.

In its final ruling, the USFWS identified a total of 19 habitat units in the states of Minnesota, Montana, Nebraska, North Dakota, and South Dakota as critical to aiding piping plover recovery (USFWS 2002). Within Montana, 40,423.1 hectares (99,887.5 acres) including four separate units comprised of various ownership patterns are designated as critical habitat (Table 2).

Table 2: Land ownership within unit boundaries for critical piping plover habitat in Montana. Data in hectares and river kilometers or (acres and river miles). Adapted from: USFWS, 2002.

\begin{tabular}{l|ccccc}
\hline \multirow{2}{*}{ Critical Habitat Unit } & \multicolumn{3}{|c}{ Ownership } \\
\cline { 2 - 6 } MT-1 Sheridan County & Federal & State & Tribal & Private & Total \\
\hline \multirow{2}{*}{ MT-2 Missouri River } & $5,405.4$ & 119.4 & & $2,254.5$ & $7,779.4$ \\
& $(13,356.8)$ & $(295.1)$ & & $(5,571)$ & $(19,222.9)$ \\
\hline \multirow{2}{*}{ MT-3 Fort Peck Reservoir } & & $* *$ & $* *$ & $* *$ & 201.8 \\
& & & & $(125.4)$ \\
MT-4 Bowdoin NWR & 31,311 & & & 31,311 \\
& $(77,370)$ & & & $(77,370)$ \\
\hline Total (acres \& river miles) & 1333.2 & & & 1333.2 \\
& $(3,294.5)$ & & & & $(3,294.5)$ \\
Total Land (\%) & $38,049.2$ & 119.4 & & $(2,254.5)$ & $(99,887.5)$ \\
\hline
\end{tabular}

** Ownership of sites along the Missouri River varies by State. In Montana, islands and sandbars are recognized as owned by the State except along the reservation boundaries of the Assiniboine and Sioux Tribes of Fort Peck; tribes own land to the mid-channel of the Missouri River adjacent to the Reservation boundary.

Sheridan County (Unit MT-1), in the extreme northeastern corner of the state, includes 20 alkali lakes and wetlands. Essential nesting habitat is dispersed throughout this unit. The Missouri River units (MT-2 and MT-3) consist of both reservoir and river reaches: Fort Peck Reservoir is located entirely within the Charles M. Russel NWR, while unit MT-2 encompasses approximately $201.8 \mathrm{~km}$ of the Missouri River just west of Wolf Point to the Montana-North Dakota border (Figure 8). 


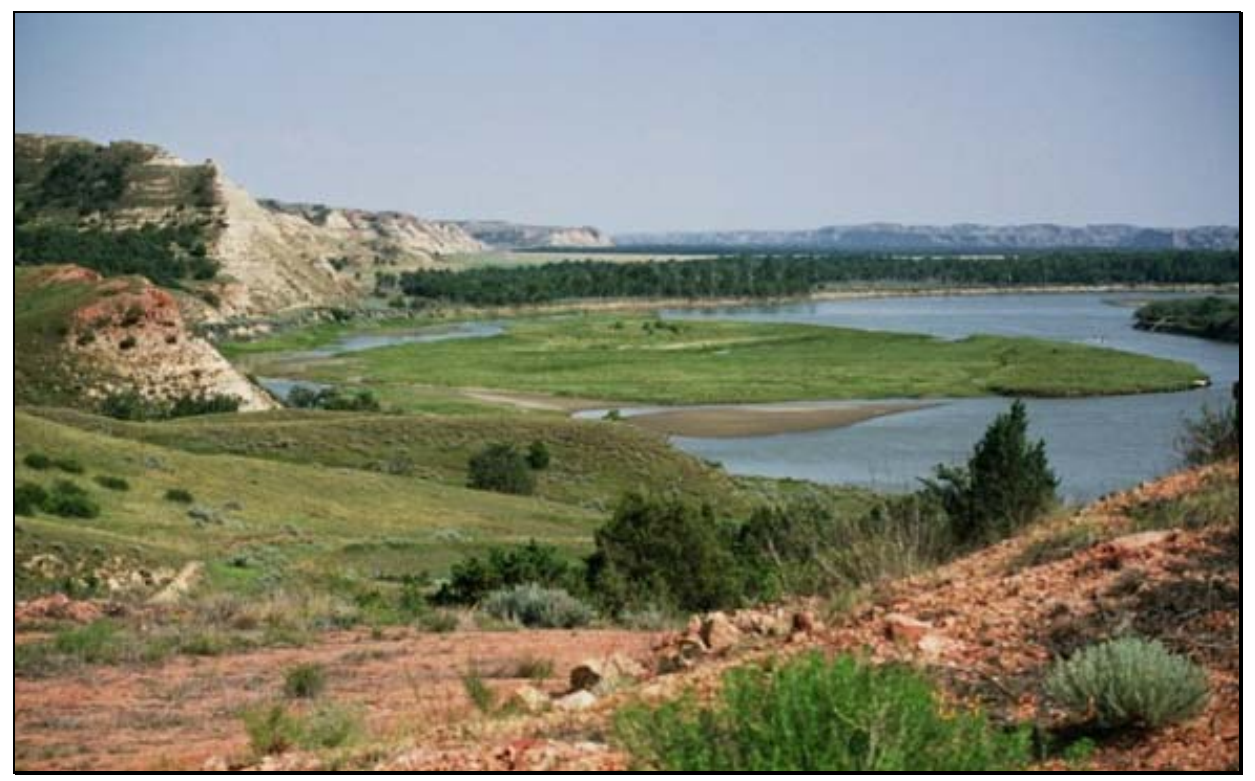

Figure 8: Critical Missouri River habitat, below Culbertson, Montana. Photo Courtesy: USGS.

The river reach below Fort Peck Reservoir to the confluence of the Milk River is not included as it is highly degraded and contains few sandbars. Bowdoin NWR is the site of the forth critical habitat unit (MT-4). Despite sporadic breeding records at Alkali Lake in Pondera County, Bowdoin NWR, located in east-central Phillips County, represents the typical western edge of the Northern Great Plains breeding population of piping plovers. Maps for all four units are presented in Appendix 5.

In Phillips County, three historic lake beds at Nelson Reservoir most likely provided essential habitat to breeding piping plovers however this area was flooded when the reservoir was created for irrigation purposes. While Nelson Reservoir was originally proposed for critical habitat inclusion, it was excluded from the final listing as a Memorandum of Understanding (MOU) between the Bureau of Reclamation (BOR), the USFWS, and local Irrigation Districts was in place that would minimize the threat of flooding to active piping plover nest sites. Additionally, as part of the terms and conditions of a 1990 biological opinion on the operation of Nelson Reservoir by the BOR, conservation measures had been employed to minimize take, and would continue.

Occupied nesting habitat on North Alkali Lake in Pondera County occurs on Blackfeet tribal land and was not designated critical habitat at the request of the tribal government. Habitat on tribal lands determined essential to conserve the species may be designated. This was the case for sand bars along the Missouri River along the Fort Peck Reservation. The USFWS believes this designation is consistent with the special trust responsibility the Federal government has to Indian people to preserve and protect their lands and resources. 


\section{LIFE HISTORY AND ECOLOGY}

\section{Migration}

Piping plovers are migratory shorebirds that spend approximately 3-4 months per year on northern U.S. and southern Canadian breeding sites. Spring arrival times vary considerably between geographic locations with coastal birds arriving at nest sites earlier than inland birds. Along the Atlantic coast, piping plovers have been observed as early as February 24 in Virginia (Cross 1991) and by late March in New England (Bent 1929, Haig and Elliot-Smith 2004). In the interior U.S., arrival times also progress northward with the first birds arriving at breeding grounds along the Platte River in mid to late April (National Research Council 2004). Along the Missouri River and at alkali lakes in the northern U.S. arrival times generally begin in the third week of April and by mid-May most piping plovers have returned to North Dakota, Minnesota, Manitoba and other inland sites (Haig 1985, Prindiville-Gaines and Ryan 1988, Haig and Elliot-Smith 2004).

Observations at inland sites during the migration period are limited and it is possible that birds travel nonstop between breeding and wintering areas (Haig 1992). Accordingly, little is known about the migratory patterns of piping plovers in Montana. Most observations have been recorded for breeding pairs, with few reported sightings of transient individuals. Limited reports of plovers during migration do, however, exist just east of the Rocky Mountains (Montana Bird Distribution Database 2005). In Montana, spring arrival of the species most often occurs from late April through early May with departure occurring by late August (Montana Piping Plover Recovery Committee 1997, Lenard et al 2003, Mike Rabenberg, pers. comm.).

Recent analysis of migration data from banded Great Lakes birds suggests that critical habitat units are used heavily during migration (Stucker and Cuthbert 2006). Further, while stopover length could not be quantified in this study the authors speculate that it may be variable in length for the Great Lakes population, ranging from several days to one month based on anecdotal reports (Stucker and Cuthbert 2006).

Departure from the breeding colony for southern wintering grounds varies by geographic location and time of nesting initiation. In North Dakota, birds will depart as early as late June or early July, however, others with late hatching nests may remain until September (Haig and Elliot-Smith 2004). Since peak return along the Texas shoreline and other Gulf coast beaches occurs in August and September (Haig and Elliot-Smith 2004) it is likely that the majority of breeding sites have been vacated by mid-August.

\section{Reproductive Biology}

Soon after arrival at the breeding ground, male piping plovers begin establishing and defending territories that encompass both a section of shoreline and an area of open ground (Whyte 1985). Typical aggressive displays between competing males include horizontal threat, parallel-run and aerial displays (Cairns 1982). Parallel runs may cover distances up to $100 \mathrm{~m}$ while aerial displays may be performed from just above ground level up to approximately $35 \mathrm{~m}$ and are generally accompanied by continuous vocalization (Cairns 1982). At the beginning of courtship, males perform elaborate flights over breeding territories to signal territory boundaries and advertise their availability to females. Pre-copulatory actions include calling, tilt displays and nest scrape displays, during which shell fragments or pebbles are 
tossed and sand is kicked backward. This creates a shallow depression that may eventually be used as a nest (Cairns 1982, Haig 1992, Haig and Elliot-Smith 2004).

Piping plovers exhibit a predominantly monogamous mating system although mate-switching may occur during the breeding season (Haig and Oring 1988c) and between years (Wilcox 1959, Haig and Oring 1988c, USFWS 1988). The ephemeral nature of most nest sites renders birds susceptible to frequent nest destruction and renesting appears to be a relatively common event (USFWS 1988). In most cases, however, individuals remain with the same mate during the breeding season (Haig and Oring 1988c). Between years, regardless of reproductive success, piping plovers usually shift mates (Wilcox 1959, Haig and Oring 1988c, Haig 1992).

Peak nesting in the Northern Great Plains extends from late April through August, with the majority of nests being initiated in May and June (Aron 2005). Both sexes participate in nest digging and the finished nest cup is frequently lined with small pebbles or shell fragments forming a shallow depression approximately $2 \mathrm{~cm}$ deep and $6 \mathrm{~cm}$ in diameter (USFWS 1994). Common nest substrates include sand, gravel and shells. Males may continue to construct additional nests in their territories that might be used to deceive predators or may simply reflect over-zealousness (Wilcox 1959).

Egg-laying commences soon after mating with a single egg being laid every other day until the clutch is complete (Wilcox 1959, Haig 1992). Eggs are pale buff in coloration (Figure 9) and are speckled with fine black, brownish-purple or purplish-black markings (Cairns 1982). Four egg-clutches are normally produced although replacement clutches tend to be smaller, averaging 2-3 eggs (Haig and Elliot-Smith 2004). Variations in clutch size do exist however, and range from 3.3 in Saskatchewan (Whyte 1985) to 3.5-3.7 in North Dakota (Prindiville-Gaines and Ryan 1988). On the Missouri River, average clutch size, based on 6,376 piping plover nest records gathered from 1988-2005, is 3.66. Montana's averages are similar: mean clutch size ranges from 3.46 at Fort Peck Reservoir to 3.77 along the Fort Peck river reach (G. Pavelka, pers. comm.).

Incubation usually begins with completion of the clutch, averages 27-30 days, and is shared equally by both sexes (Wilcox 1959, Cairns 1977, MacIvor 1990). Eggs begin to hatch from late May to mid-June at many inland sites (USFWS 1988) but in Montana this rarely occurs before mid-June (Jake Ivan pers. comm.).

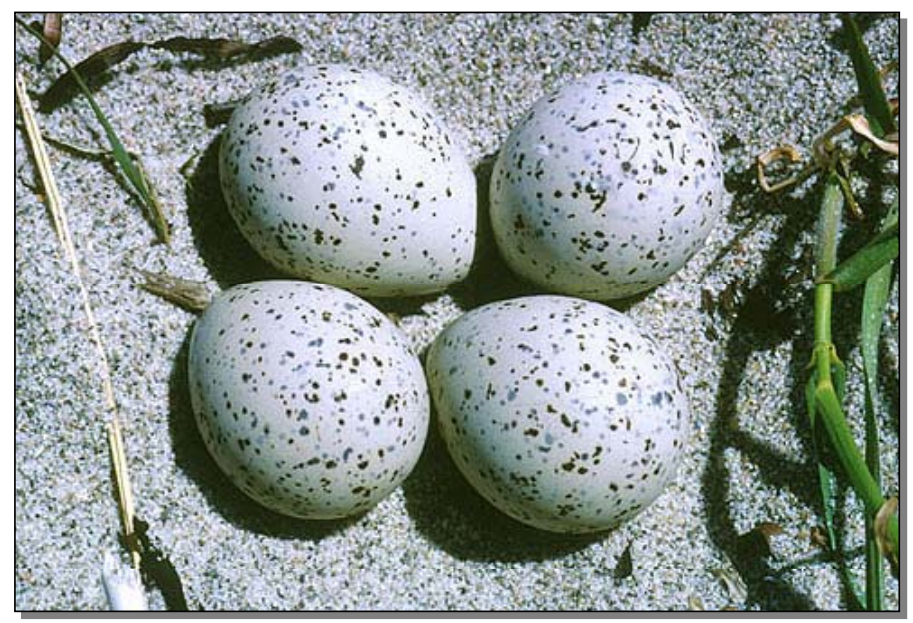

Figure 9: Typical clutch of piping plover eggs Photo Courtesy: Environment Canada - G. K. Peck.

Chicks are precocial and often leave the nest within two to three hours of hatching (Haig 1992). Although they peck at the ground almost immediately, Cairns (1977) suggests that they probably obtain little nourishment for several days. Broods generally remain on nesting territories but may expand their 
movements as they mature or are disturbed (USFWS 1988). After hatching, parental care appears to vary: some broods are cared for by both parents while in others, females desert the brood within 5-10 days leaving the male to complete the process (Haig and Oring 1988c).

Chicks require more than 21 days of growth and development before they are able to fly (National Research Council 2004). They typically fledge 20-35 days after hatching (Cairns 1982, Haig 1987, Prindiville-Gaines and Ryan 1988, Wilcox 1959) and are capable of sustained flight soon thereafter. After fledging, young birds continue to mature and feed alongside adults on undefended staging grounds prior to autumn departure in mid to late August (Cairns 1977, Prindiville-Gaines and Ryan 1988, National Research Council 2004).

\section{Population Biology and Demography}

While plovers are known to begin breeding at one year of age (MacIvor 1990, Strauss 1990, Haig 1992, Amirault et al 2006), preliminary information from banding studies in Prairie Canada suggest that this may not be the case in all regions (Cheri Gratto-Trevor, pers. comm.). In this recent study, half of all females nested as yearlings, an additional $30 \%$ nested in their second year, and the remaining birds initiating nesting in later years. In spite of this, once nesting is initiated, plovers typically attempt to breed every year, producing one brood per season (Haig 1992). Plovers will return to former breeding sites, but the ephemeral nature of their nesting habitat often forces them to disperse large distances between years (Haig and Oring 1988b, Haig 1992, Haig and Elliot-Smith 2004). Consequently, estimates of site fidelity are highly variable, and range from $25 \%$ to $84 \%$ (Haig and Elliot-Smith 2004).

Piping plover reproductive success is generally low and highly variable among sites and years (Haig and Oring 1987). For example, reproductive success at alkaline wetlands in the Great Plains is estimated at 0.89 fledgling per pair (Larson et al 2002). At river sites and reservoirs, success is lower, averaging 0.73 (Larson et al, 2002). As natal site fidelity is also low (20\%), first year survival is difficult to estimate. Larson et al (2000), however, estimate survival from fledging to first year at 0.318 while PrindivilleGaines and Ryan (1998) suggest rates of juvenile survival ranging from 0.507-0.634.

Based on banding studies, piping plovers can live up to 14 years (Wilcox 1962, Clapp et al 1982) but very few individuals survive beyond the age of nine (Wilcox 1959, 1962). In fact, longevity records from New York State indicate that only $13 \%$ of females and $28 \%$ of males live to be five years of age or older (Wilcox 1959). Data on annual adult survival rate for the Great Plains has been revised over time from 0.66 (Root et al 1993) to 0.737 (Larson et al 2000). Survival rates from band re-sightings studies are, however, likely minimum estimates as mark-recapture analyses treat permanent migration as mortality (Lebreton et al 1992, Larson et al 2002). Thus, such estimates most likely represent worst-case survival (Larson et al 2002).

\section{Foraging Ecology and Diet Composition}

A dearth of information exists regarding diet composition in piping plovers. The precarious status of the species precludes sacrificing individuals for stomach content analysis and as a consequence past studies have tended to be restricted to observations of feeding individuals and/or analysis of fecal samples (Shaffer and Laporte 1994). While such techniques allow a qualitative assessment to be made, these 
methods may be unreliable indicators of the diversity of species consumed. For example, soft-bodied invertebrates may be poorly represented or difficult to identify (Shaffer and Laporte 1994).

Despite such difficulties, studies suggest that on breeding grounds, plovers feed on a variety of invertebrates including marine worms, fly larvae, beetles, spiders, grasshoppers, crustaceans and mollusks (Bent 1929, Cairns 1977, USFWS 1988, Nicholls 1989, Shafer and Laporte 1994). Along the Atlantic coastline, fecal analysis also identified the presence of various animal classes namely: Gastropoda, Amphipoda, Coleoptera, Diptera and Hymenoptera (Shafer and Laporte 1994). Moreover, the authors speculate that because organisms found in the droppings were principally adult organisms living at the beach surface, plovers may locate prey primarily by sight (Shaffer and Laporte 1994).

\section{POPULATION STATUS}

\section{Population Status in the U.S.}

Historical piping plover population trend data are generally nonexistent (USFWS 1988), but early $20^{\text {th }}$ century accounts indicate that uncontrolled hunting for the plume industry played a significant role in the first major decline of the species (Bent 1929). Passage of the Migratory Bird Treaty Act in 1918, which prohibited the sale, purchase, taking or possession of any wild migratory bird, allowed the species to recover in the 1920s (USFWS 1988). This recovery was short-lived, however. Beginning in the 1940s, human development pressures and the use of plover nesting beaches for recreation and housing contributed to the subsequent decline (Tate 1981, Haig and Oring 1985). In addition, in the interior U.S., river channelization and levee construction led to the destruction and alteration of natural nesting sandbar habitat (USFWS 1988).

Prior to 1981, the majority of information pertaining to the status of piping plovers was provided in breeding studies conducted by Wilcox (1959) and Cairns (1977). These studies are, however, regional in nature, and offer little information on the condition of either the breeding or winter populations. Breeding surveys conducted in the early 1980s reported 2,137 to 2,684 adult plovers in the Northern Great Plains/Prairie region, 28 adults in the Great Lakes region, and 1,370-1,435 adults along the Atlantic coast (Haig and Oring 1985, USFWS 1988). Although such efforts provided much needed data, breeding sites on the periphery (e.g. Montana, Colorado and Saskatchewan) of the species range were incompletely censused (Haig and Plissner 1993). In addition, lack of historical population estimates made it difficult to put these data into perspective (Haig and Oring 1987).

Attempts at annual region-wide counts began in 1986 (USFWS 1988). In some areas, counts were probably reasonably complete, but elsewhere they were sporadic (Ryan et al 1993). Survey effort increased dramatically in 1991 and since that time range-wide censuses of piping plovers have been conducted every five years at both breeding (Atlantic coast, Great Lakes region, Canadian prairies/U.S. Northern Great Plains) and wintering grounds (Atlantic and Gulf coasts). During this time period, the Atlantic and Great Lakes populations of piping plovers have shown consistent population increases, with a 78\% increase in the Atlantic coast population from 1991 to 2001 and an $80 \%$ increase in the Great Lakes population (Haig et al 2005). Conversely, a total of 1,981 piping plovers were recorded in the U.S. Northern Great Plains in 2001, indicating that the population has declined 2.5\% between $1991(\mathrm{n}=2,032)$ and 2001 but increased 23.4\% between $1996(n=1,599)$ and 2001 (Table 3). Inclusion of results from 
Prairie Canada reveals a starker trend however. The Northern Great Plains population declined 10.1\% between the 1996 and 2001 international censuses. Over a 15 year period, the trend is even more worrisome; between 1991 and 2001 the number of breeding birds in the Northern Great Plains declined approximately $15 \%$, from 3,469 to 2,953 .

Of particular importance to conservation planning and assessment is sub-regional variation between sites and years. Numbers have declined throughout much of the U.S. Northern Great Plains since 1996, but overall the trend is positive (Plissner and Haig 1997, Ferland and Haig 2001). As a significant increase in adult birds (460\%) was detected on the Missouri River between 1996 and 2001, the increase in the U.S. Northern Great Plains population during this time period can most likely be attributed to substantial increases along this river system. For example, when data for the Missouri River were excluded, birds in North Dakota declined on alkali lakes by 31.5\% (Haig et al 2005). Regardless of temporal and spatial variation, birds at most inland sites have failed to reach specified recovery levels and the Northern Great Plains population as a whole continues to decline.

Assertions regarding population sizes necessary for recovery can be tested with viability modeling (National Research Council, 2004) and as a result, population viability analysis (PVA) has become an important tool in the management of threatened and endangered species. In its broadest sense, PVA is a collection of methods for evaluating the threats faced by populations or species, their risk of extinction or decline, and their chances of recovery (Keedwell 2004). Three PVAs have been published for the Northern Great Plains population of piping plovers (Ryan et al 1993, Plissner and Haig 2000, Larson et al 2000, 2002). While results from the 1991 and 1996 international censuses identified a 1-3\% annual decline in piping plover abundance, PVAs indicate that the decline is potentially more rapid (Ryan et al 1993, Plissner and Haig 2000, Larson et al 2002). For example, in a population growth model developed by Ryan et al (1993), the Great Plains plover population was shown to decline $7 \%$ annually. In addition, the authors surmised that even under the most favorable demographic conditions, the most realistic projections indicated extirpation in approximately 80 years.

A reoccurring problem in analyzing piping plover population viability is that these models are most sensitive to adult survival estimates (Ryan et al 1993, Plissner and Haig 2000) yet survival is difficult to estimate accurately (Haig and Elliot-Smith 2004). This may be particularly true in the Great Plains where ephemeral breeding habitats may reduce site fidelity and therefore lower resighting probability (Haig and Elliot-Smith 2004). Models based on revised adult survival estimates of $73 \%$ suggest, however, that with increased levels of management, the Great Plains population could also persist (Larson et al, 2000; 2002). Based on preliminary results from Gratto-Trevor's work in Prairie Canada (see Population Biology and Demography section), there is, however, a need to revisit this model as Larson et al (2000) assumed that all females initiated breeding as yearlings. 
Table 3. Summary of 1991, 1996 and 2001 International Piping Plover Breeding Censuses in the Northern Great Plains. Adapted from: Haig et al 2005.

\begin{tabular}{|c|c|c|c|c|c|}
\hline \multirow{2}{*}{ State/Province } & \multicolumn{3}{|c|}{ Adults } & \multirow{2}{*}{$\begin{array}{l}\text { \% change } \\
1991-2001\end{array}$} & \multirow{2}{*}{$\begin{array}{l}\text { \% change } \\
1996-2001\end{array}$} \\
\hline & 1991 & 1996 & 2001 & & \\
\hline \multicolumn{6}{|l|}{ Prairie Canada } \\
\hline Alberta & 180 & 276 & 150 & -16.7 & -45.7 \\
\hline Saskatchewan & 1,172 & 1,348 & 805 & -31.3 & -40.3 \\
\hline Manitoba & 80 & 60 & 16 & -80.0 & -73.3 \\
\hline Ontario & 5 & 3 & 1 & -80.0 & -66.7 \\
\hline \multicolumn{6}{|l|}{ U.S Northern Great Plains } \\
\hline Minnesota & 13 & 10 & 7 & -46.2 & -30.0 \\
\hline Montana & 308 & 153 & 137 & -55.5 & -10.5 \\
\hline Missouri River & $26^{c}$ & $24^{c}$ & 7c & $\mathrm{n} / \mathrm{a}^{\mathrm{b}}$ & $\mathrm{n} / \mathrm{a}^{\mathrm{b}}$ \\
\hline North Dakota & 992 & 1,004 & 1,112 & 12.1 & 10.8 \\
\hline Missouri River & $307^{c}$ & $125^{c}$ & $643^{c}$ & $\mathrm{n} / \mathrm{a}^{\mathrm{b}}$ & $\mathrm{n} / \mathrm{a}^{\mathrm{b}}$ \\
\hline South Dakota & 295 & 29 & 390 & 32.2 & $1,244.8$ \\
\hline Missouri River & $292^{c}$ & $29 c$ & $390^{c}$ & $\mathrm{n} / \mathrm{a}^{\mathrm{b}}$ & $\mathrm{n} / \mathrm{a}^{\mathrm{b}}$ \\
\hline Nebraska & 398 & 375 & 308 & -22.6 & -17.9 \\
\hline Missouri River & $0^{c}$ & $9^{c}$ & $8^{c}$ & $\mathrm{n} / \mathrm{a}^{\mathrm{b}}$ & $\mathrm{n} / \mathrm{a}^{\mathrm{b}}$ \\
\hline Missouri River (combined) & $625^{c}$ & $187^{c}$ & $1,048^{\mathrm{c}}$ & 67.7 & 460.4 \\
\hline Iowa & 13 & 14 & 11 & -15.4 & -21.4 \\
\hline Kansas & 0 & 1 & 3 & 300.0 & 200.0 \\
\hline Colorado & 13 & 13 & 13 & 0.0 & 0.0 \\
\hline Oklahoma & 0 & n.s. ${ }^{a}$ & n.s. ${ }^{a}$ & $\mathrm{n} / \mathrm{a}^{\mathrm{b}}$ & $\mathrm{n} / \mathrm{a}^{\mathrm{b}}$ \\
\hline \multicolumn{6}{|l|}{ Totals } \\
\hline Prairie Canada & 1,437 & 1,687 & 972 & -32.4 & -42.4 \\
\hline U.S. Northern Great Plains & 2,032 & 1,599 & 1,981 & -2.5 & 23.9 \\
\hline $\begin{array}{l}\text { Prairie Canada/Northern } \\
\text { Great Plains }\end{array}$ & 3,469 & 3,286 & 2,953 & -14.9 & -10.1 \\
\hline
\end{tabular}

${ }^{a}$ n.s. $=$ not surveyed.

${ }^{\mathrm{b}} \mathrm{n} / \mathrm{a}=$ not applicable.

${ }^{\mathrm{c}}$ subtotals for reference only. Missouri River results by state are included in state totals.

From a global perspective, each year the World Conservation Union (IUCN) evaluates the extinction risk of thousands of species and subspecies worldwide and reports such findings in its Red List.

Interestingly, in 2005, IUCN downgraded the piping plover from vulnerable to near threatened (IUCN, 2005). Extrapolating the 1991 and 1996 breeding census data to a ten year period (the relevant trend period under the IUCN Red List criteria) for 1995-2005, the IUCN determined that the rates of change for piping plovers equated to a total population increase of $9.5 \%$ (using the 1996 data) to $32.6 \%$ (using the 1991 data), even though the 1996-2001 data indicate a slight decline of the Great Plains population. While 
it recognized that such increases were the result of sustained management initiatives, upon which populations remain dependent, based on its own criteria, the piping plover was downgraded. In light of the population decline in Prairie Canada (-32.4\% from 1991-2001) it is probable that IUCN will reconsider this listing after the 2006 International Piping Plover Census.

\section{Population Status in Montana}

\section{Population Size}

Since 1988, piping plover surveys have been conducted on an annual basis in portions of the state believed to correspond to potential breeding habitat. In addition, Montana has participated in all three international censuses, conducted in 1991, 1996 and 2001. The international census represents a rapid snapshot during a two week time interval, whereas annual surveys may be conducted over a more protracted period during the breeding season. Despite this, total numbers of birds recorded are similar and trends consistent between years.

The largest population of piping plovers recorded in Montana occurred during the 1991 breeding season (Figure 10) and was primarily a result of the substantial increase in birds recorded at alkali wetland sites in the Northeast Montana WMD (Table 4). Surveys conducted in this region have consistently recorded higher numbers of nesting birds, compared to other areas in Montana, and this area represents approximately $68 \%$ of the statewide population (Figure 11). Furthermore, combined survey data from 1988 to 2005 (Table 4) also reveal that approximately $84 \%$ of the total number of plovers recorded over this 18 year period occurred within Sheridan County (i.e. Northeast Montana WMD and Medicine Lake NWR).

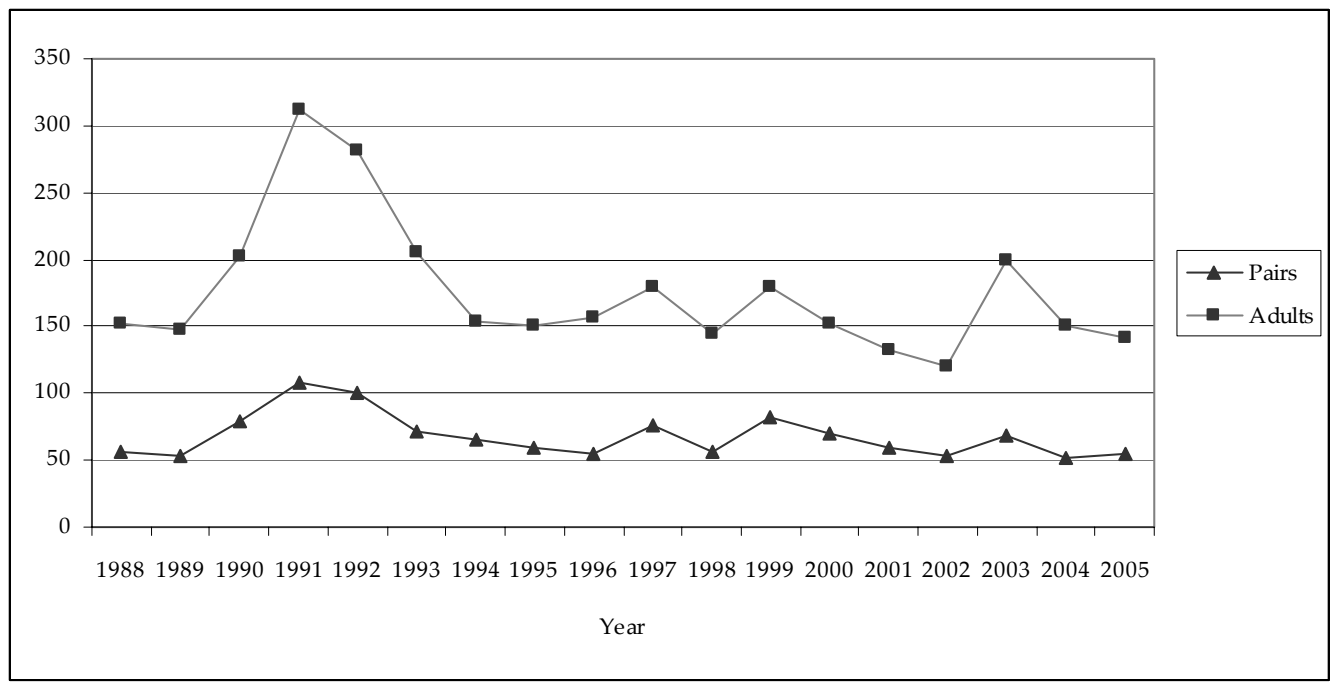

Figure 10: Numbers of breeding pairs and adults recorded in Montana, based on combined surveys conducted between 1988 and 2005.

Combined survey data gathered over the past ten year trend period do, however, show changes in the relative proportion of birds nesting at regional sites (Figure 12). While the Northeast Montana WMD continues to support the largest proportion of breeding birds, sites such as Medicine Lake have failed to 
attract large numbers of breeding plovers since the drought periods of the early 1990s. Consistently high water levels over the past ten years have inundated the lake shoreline, reducing or eliminating suitable habitat. Such results suggest that given additional management actions, the state can support a larger population of breeding birds than is currently present, but numbers have failed to return to levels attained in the early 1990s.

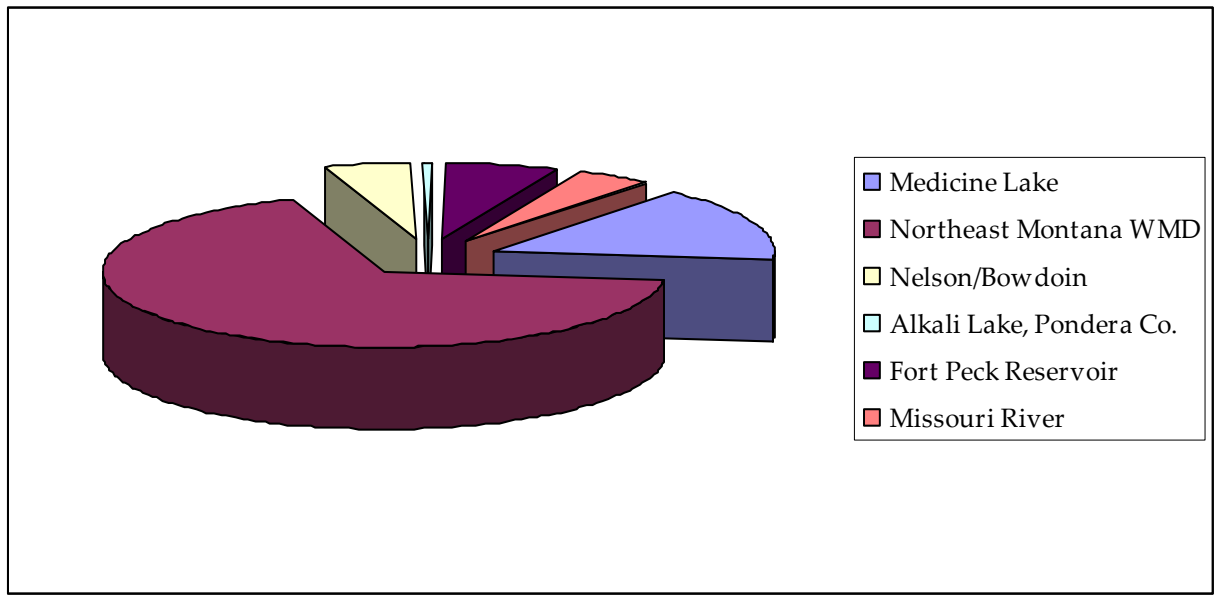

Figure 11: Distribution of adult piping plovers in Montana, based on combined survey results between 1988 and 2005.

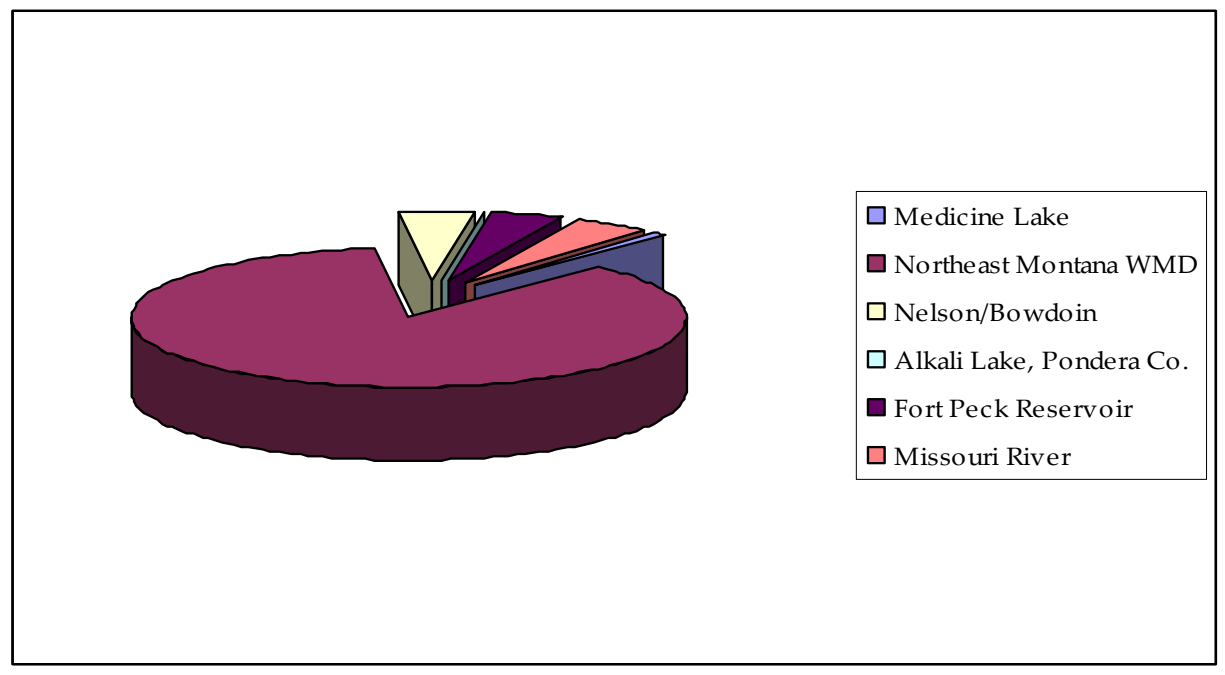

Figure 12: Distribution of adult piping plovers in Montana, based on combined ten-year survey results between 1996 and 2005.

Plover numbers clearly fluctuate widely at the local scale, most likely as a result of changing water levels within the state, adjoining states, and Canada. Available habitat may increase or decline and consequently birds may not return to exactly the same locations between breeding seasons (Haig and Oring 1988b). Montana also represents the westernmost edge of the breeding range in the U.S. and this may affect the numbers of birds that ultimately reach the Missouri River, Fort Peck Reservoir or alkali lakes region in any given year. 
Within the U.S. Alkali Lakes region, which extends from North Dakota into northeastern Montana and includes the Northeast Montana WMD and Medicine Lake NWR, numbers have declined over the past two years (Table 4). Water levels at Lake Sakakawea have remained well below normal, exposing large stretches of gravel beach suitable for nesting plovers. Moreover, the number of breeding pairs recorded on Lake Sakakawea has dramatically increased during this time; 752 adults were recorded in 2005 (USACE, G. Pavelka, pers. comm.) and 220 adults were seen on the Garrison River (Ryba 2005). It is possible that many plovers have shifted breeding sites to take advantage of present beach conditions at Lake Sakakawea (Ryba 2004).

Similar population shifts were noted during the 1996 and 1997 breeding seasons. Near record runoff and associated USACE flood control activities along the Missouri, resulted in substantial habitat inundation on Lake Sakakawea and the Missouri River below Garrison Dam (USACE 1997). Sizeable decreases in piping plover numbers were recorded in this region. In comparison, the largest number of breeding pairs recorded in the Northeast Montana WMD, and along the Fort Peck River reach, occurred during the 1997 breeding season (Table 5). At the same time, reduced flow releases from Fort Peck, resulted in record high water levels behind the dam. Beaches typically used by piping plovers were inundated (USACE 1997) and no birds were recorded in either 1996 or 1997 (Tables 4 and 5). Given the ephemeral nature of breeding sites, the smaller numbers of plovers recorded in Montana in recent years, may be in part, a reflection of river conditions within the Missouri River drainage. Without banding, however, it is impossible to accurately determine survivorship or dispersal patterns.

Owing to the prolonged drought period that affected the region between 2000 and 2004, water levels at Fort Peck Reservoir have experienced a dramatic decrease (MFWP 2005) and essential breeding habitat along the shoreline has been exposed. Plover numbers have increased for the first time in more than a decade, and in 2005, the second highest number of birds ( $n=26)$, since monitoring efforts began in 1988, was recorded along the reservoir. Conversely, poor numbers were recorded along the Fort Peck river reach of the Missouri. As with the alkali lakes region, this may be linked to exceptionally high habitat availability on the shorelines of Lake Sakakawea.

A small number of plovers utilize wetland sites in the Milk River Basin, Phillips County, but nesting is sporadic and numbers oscillate between years, most likely due to fluctuating water levels and habitat availability. Surveys conducted over the past five years (2001-2005) indicate that birds pass through this region but apparently shift sites in search of suitable nesting habitat. For example, although a total of 26 birds have been observed in this area during annual surveys, only four records of breeding pairs have been noted at Nelson Reservoir. No breeding records exist for Bowdoin NWR or Hewitt Lake NWR. 
Table 4: Estimated numbers of adult piping plover in Montana based on annual survey results, 19882005. Data from unpublished reports prepared by: The Nature Conservancy, USACE, and USFWS.

\begin{tabular}{|c|c|c|c|c|c|c|c|}
\hline Year & $\begin{array}{r}\text { Medicine } \\
\text { Lake NWR }\end{array}$ & $\begin{array}{r}\text { Northeast } \\
\text { Montana } \\
\text { WMD }\end{array}$ & $\begin{array}{r}\text { Nelson/ } \\
\text { Bowdoin/ } \\
\text { Hewitt }\end{array}$ & $\begin{array}{l}\text { Alkali Lake } \\
\text { Pondera Co. }\end{array}$ & $\begin{array}{l}\text { Fort Peck } \\
\text { Reservoir }\end{array}$ & $\begin{array}{r}\text { Missouri } \\
\text { River }\end{array}$ & Total \\
\hline 1988 & 43 & 59 & 20 & 5 & 20 & 5 & 152 \\
\hline 1989 & 11 & 95 & 14 & 4 & 12 & 11 & 147 \\
\hline 1990 & 76 & 73 & 6 & 9 & 22 & 17 & 203 \\
\hline 1991 & 95 & 181 & 10 & 0 & 18 & 8 & 312 \\
\hline 1992 & 113 & 125 & 17 & - & 26 & 0 & 281 \\
\hline 1993 & 93 & 71 & 8 & - & 30 & 4 & 206 \\
\hline 1994 & 46 & 93 & 3 & - & 4 & 8 & 154 \\
\hline 1995 & 3 & 112 & 10 & - & 5 & 20 & 150 \\
\hline 1996 & 1 & 122 & 9 & 0 & 0 & 24 & 156 \\
\hline 1997 & 0 & 151 & 5 & - & 0 & 23 & 179 \\
\hline 1998 & 0 & 127 & 11 & - & 4 & 2 & 144 \\
\hline 1999 & 0 & 161 & 12 & - & 2 & 4 & 179 \\
\hline 2000 & 0 & 144 & 2 & - & 2 & 4 & 152 \\
\hline 2001 & 0 & 122 & 4 & 0 & 4 & 3 & 133 \\
\hline 2002 & 13 & 95 & 8 & - & 2 & 2 & 120 \\
\hline 2003 & 0 & 173 & 4 & - & 17 & 6 & 200 \\
\hline 2004 & 0 & 139 & 2 & - & 9 & 0 & 150 \\
\hline 2005 & 1 & 105 & 8 & - & 26 & 2 & 142 \\
\hline Total & 495 & 2,148 & 153 & 18 & 203 & 143 & 3,160 \\
\hline Mean & 27.5 & 119.3 & 8.5 & 3 & 11.3 & 7.9 & 175.6 \\
\hline$S D$ & 39.76 & 34.96 & 5.04 & 3.69 & 10.2 & 7.8 & 50.4 \\
\hline
\end{tabular}

Montana has elected to use a ten-year running average for trend analysis and management planning. The population over the past ten-year period (1996-2005) has averaged 156 adult birds (ranging from 120-200) and 63 breeding pairs (ranging from 52-82). These data indicate that Montana has met and/or exceeded the recovery goal of 60 breeding pairs as set forth in the 1988 USFWS document. The most recent running five-year averages are, however, slightly lower. Means of 149 adults and 57.4 breeding pairs were recorded. While surveys in some areas represent sub-samples, and the number of plovers in Montana is close to that outlined in the recovery plan (USFWS 1988), the last five years have recorded relatively fewer breeding pairs than in previous years (Table 5). 
Table 5: Estimated numbers of piping plover pairs in Montana based on annual survey results, 19882005. Data from unpublished reports prepared by: The Nature Conservancy, USACE, and USFWS.

\begin{tabular}{|c|c|c|c|c|c|c|c|}
\hline Year & $\begin{array}{r}\text { Medicine } \\
\text { Lake NWR }\end{array}$ & $\begin{array}{r}\text { Northeast } \\
\text { Montana } \\
\text { WMD }\end{array}$ & $\begin{array}{r}\text { Nelson/ } \\
\text { Bowdoin/ } \\
\text { Hewitt }\end{array}$ & $\begin{array}{l}\text { Alkali Lake } \\
\text { Pondera Co. }\end{array}$ & $\begin{array}{l}\text { Fort Peck } \\
\text { Reservoir }\end{array}$ & $\begin{array}{r}\text { Missouri } \\
\text { River }\end{array}$ & Total \\
\hline 1988 & 17 & 22 & 9 & 0 & 5 & 3 & 56 \\
\hline 1989 & 5 & 34 & 4 & 0 & 6 & 5 & 54 \\
\hline 1990 & 28 & 33 & 2 & 0 & 10 & 6 & 79 \\
\hline 1991 & 31 & 64 & 3 & 0 & 8 & 2 & 108 \\
\hline 1992 & 34 & 49 & 6 & - & 11 & 0 & 100 \\
\hline 1993 & 32 & 22 & 3 & - & 14 & 1 & 72 \\
\hline 1994 & 19 & 33 & 1 & 0 & 11 & 1 & 65 \\
\hline 1995 & 1 & 41 & 4 & - & 10 & 3 & 59 \\
\hline 1996 & 0 & 49 & 0 & - & 0 & 6 & 55 \\
\hline 1997 & 0 & 70 & 0 & - & 0 & 6 & 76 \\
\hline 1998 & 0 & 51 & 4 & - & 1 & 1 & 57 \\
\hline 1999 & 0 & 74 & 5 & - & 1 & 2 & 82 \\
\hline 2000 & 0 & 66 & 1 & - & 1 & 2 & 70 \\
\hline 2001 & 0 & 54 & 1 & 0 & 2 & 2 & 59 \\
\hline 2002 & 6 & 43 & 2 & - & 1 & 1 & 53 \\
\hline 2003 & 0 & 58 & 0 & - & 7 & 3 & 68 \\
\hline 2004 & 0 & 48 & 1 & - & 4 & 0 & 53 \\
\hline 2005 & 0 & 42 & 1 & - & 11 & 1 & 55 \\
\hline Total & 173 & 853 & 47 & 0 & 103 & 45 & 1,221 \\
\hline Mean & 9.6 & 47.4 & 2.6 & 0 & 5.7 & 2.5 & 67.8 \\
\hline$S D$ & 13.23 & 15.32 & 2.46 & 0 & 4.7 & 2.1 & 16.2 \\
\hline
\end{tabular}

\section{Productivity and Reproductive Success}

Along the Missouri River, below Fort Peck Dam, and along the shores of Fort Peck Reservoir, the USACE has undertaken piping plover productivity monitoring since 1988. Fledge ratios are determined as the number of fledged chicks per pair of adult birds counted during the annual census that year. As data gathered between 1988 and 2001 represents a reach sub-sample (G. Pavelka, pers comm.), productivity data for the 2002-2005 breeding seasons may provide a more thorough assessment of reproductive success in these two critical habitat units. During these years, fledge ratios fluctuated between 0.35 and 2.22 fledgling per pair of adult birds at reservoir nest sites (Table 6). On the Missouri River, ratios varied between 0.00 and 4.00 (Table 7). The mean fledge ratio at Fort Peck Reservoir dropped below that set forth (1.36 fledglings/pair) in the USFWS Biological Opinion (2003), but yearly ratios did not fluctuate as dramatically as fledge ratios along the Missouri River. Although the average fledge ratio along the Missouri River was high (2.40), reproductive success varied greatly between years. Moreover, the number of adult plovers was small and while ratios look promising, the number of chicks fledged $(\mathrm{n}=12)$ in this region over the last four years is small. 
Table 6: Estimates of piping plover reproduction on Fort Peck Reservoir, 2002-2005. Data from USACE, G. Pavelka, pers. comm.

\begin{tabular}{ccccccccc}
\hline Year & $\begin{array}{c}\text { Adult } \\
\text { Census }\end{array}$ & Nests & $\begin{array}{c}\text { Nest } \\
\text { Hatching }\end{array}$ & $\begin{array}{c}\text { Nest }^{(\mathbf{a})} \\
\text { Success }\end{array}$ & Eggs & $\begin{array}{c}\text { Eggs } \\
\text { Hatching }\end{array}$ & $\begin{array}{c}\text { Chicks } \\
\text { Fledge }\end{array}$ & $\begin{array}{c}\text { Fledge }^{(\mathbf{b})} \\
\text { Ratio }\end{array}$ \\
\hline 2002 & 2 & 1 & 1 & 100.0 & 3 & 3 & 2 & 2.00 \\
2003 & 17 & 7 & 3 & 42.9 & 20 & 9 & 3 & 0.35 \\
2004 & 9 & 4 & 4 & 100.0 & 14 & 14 & 10 & 2.22 \\
2005 & 26 & 11 & 7 & 63.6 & 36 & 20 & 14 & 1.08 \\
\hline Total & 54 & 23 & 15 & 65.2 & 73 & 46 & 29 & 1.07 \\
Mean & 13.5 & 5.75 & 3.75 & & 18.3 & 11.5 & 7.25 & \\
\hline
\end{tabular}

$\mathrm{a}=$ nests per 100 attempts

$\mathrm{b}=$ fledged chicks per pair of adult birds (does not include collected fledged)

Table 7: Estimates of piping plover reproduction on the Fort Peck River Reach of the Missouri River, 2002-2005. Data from USACE, G. Pavelka, pers. comm.

\begin{tabular}{lcccccccc}
\hline Year & $\begin{array}{c}\text { Adult } \\
\text { Census }\end{array}$ & Nests & $\begin{array}{c}\text { Nest } \\
\text { Hatching }\end{array}$ & $\begin{array}{c}\text { Nest }^{(\text {a) }} \\
\text { Success }\end{array}$ & Eggs & $\begin{array}{c}\text { Eggs } \\
\text { Hatching }\end{array}$ & $\begin{array}{c}\text { Chicks } \\
\text { Fledge }\end{array}$ & $\begin{array}{c}\text { Fledge }^{(\mathbf{b})} \\
\text { Ratio }\end{array}$ \\
\hline 2002 & 2 & 1 & 0 & 0.0 & 4 & 0 & 0 & 0.00 \\
2003 & 6 & 3 & 2 & 66.7 & 12 & 8 & 8 & 2.67 \\
2004 & 0 & 0 & 0 & 0.0 & 0 & 0 & 0 & 0.00 \\
2005 & 2 & 1 & 1 & 100.0 & 4 & 4 & 4 & 4.00 \\
\hline Total & 10 & 5 & 3 & 60.0 & 20 & 12 & 12 & 2.40 \\
Mean & 2.5 & 1.25 & 0.75 & & 5 & 3 & 3 & \\
\hline
\end{tabular}

$\mathrm{a}=$ nests per 100 attempts

$\mathrm{b}=$ fledged chicks per pair of adult birds (does not include collected fledged)

Such data provides a good assessment of productivity during a limited time period, but plovers clearly respond to changes in habitat availability at the landscape level: both spatial and temporal distribution patterns shift in response to water levels and habitat availability (Skagen and Thompson 2005). In light of such variation, survey data gathered prior to 2002, combined with census data from 2002 through 2005, may provide a more accurate reflection of long term variation and trends. Ten-year fledge ratios between 1996 and 2005 varied from 0.00 to 2.22 along reservoir beaches and from 0.00 to 4.00 on the Missouri River. Along the Missouri River, the mean fledge ratio (3.27) during this time was higher than that required by the USFWS (2003). The fledge ratio at Fort Peck Reservoir (2.5) was also high, but ratios exhibited tremendous variation between years. These data suggest that piping plovers at riverine sites in Montana can attain high levels of productivity.

Within the northeastern part of the state, consistent productivity data, combined from both caged and unprotected nest sites, have been collected since 1996 (A. Ryba, pers. comm.). Over this ten-year time period, fledge ratios fluctuated between 0.67 and 1.62 at alkali wetlands and sloughs, averaging 1.28 
chicks per pair of breeding adults (Table 8). Although the ten-year mean fledge ratio at alkali sites was lower than that reported for river and reservoir sites in Montana, fledge ratios exhibited less variation between years. Moreover, the total number of chicks fledged was considerably higher $(n=545)$ than the number fledged along the Missouri River $(n=22)$ or at Fort Peck Reservoir $(n=28)$.

Table 8: Combined estimates of piping plover reproduction for Medicine Lake NWR and Northeastern Montana WMD, 1996-2005. Data from USFWS, A. Ryba, pers. comm.

\begin{tabular}{lccccc}
\hline Year & $\begin{array}{c}\text { Adult } \\
\text { Census }\end{array}$ & $\begin{array}{c}\text { Pairs } \\
\text { Monitored }\end{array}$ & Nests ${ }^{(a)}$ & $\begin{array}{c}\text { Chicks } \\
\text { Fledged }\end{array}$ & $\begin{array}{c}\text { Fledge } \\
\text { Ratio }\end{array}$ \\
\hline 1996 & 123 & 15 & 15 & 10 & 0.67 \\
1997 & 151 & 45 & 45 & 73 & 1.62 \\
1998 & 127 & 34 & 34 & 38 & 1.12 \\
1999 & 161 & 61 & 63 & 85 & 1.39 \\
2000 & 144 & 46 & 47 & 61 & 1.33 \\
2001 & 122 & 41 & 41 & 54 & 1.32 \\
2002 & 108 & 42 & 45 & 30 & 0.71 \\
2003 & 173 & 53 & 54 & 77 & 1.45 \\
2004 & 139 & 45 & 48 & 61 & 1.36 \\
2005 & 106 & 45 & 47 & 56 & 1.24 \\
\hline Total & 1,354 & 427 & 439 & 545 & $1.28^{(\mathrm{b})}$ \\
Mean & 135.4 & 42.7 & 43.9 & 54.5 & \\
\hline
\end{tabular}

(a) total number of nests higher than total number of pairs due to re-nesting

(b) ratio calculated using combined data from both caged/fenced and unprotected nest sites

\section{FACTORS AFFECTING CURRENT POPULATION LEVELS}

Habitat degradation and loss, human-related disturbance and increased predation pressures have been identified as primary agents of decline for piping plovers throughout their breeding range (USFWS 1988). Piping plovers rely on a diverse array of habitats during the breeding season (Haig 1992) and as such, many of the anthropogenic factors that limit survivorship or decrease nesting success are regional in nature. In the Northern Great Plains, habitat loss and alteration pose the greatest risk to plovers nesting along major rivers and reservoirs. At alkaline wetlands, predation of chicks and eggs is the primary threat facing breeding birds (Larson et al 2003). In addition, recent research indicates that localized food shortages near breeding sites, particularly along major rivers, may impact chick survival, thereby limiting productivity, survivorship and reproductive success (USFWS 2003).

\section{Habitat Alteration and Loss}

Channelization, bank stabilization, and construction of reservoirs to meet flood control, hydroelectric and navigation objectives have all contributed to the degradation or loss of much of the piping plover's sandbar nesting habitat (USFWS 1990). In the Missouri River valley hundreds of kilometers of historic sandbar habitat have been destroyed (USFWS 1988, Sidle et al 1992) and the construction of reservoirs has impounded almost a third of the river (USFWS 2003). Similarly, sandbar habitat along the upper Platte 
River has largely disappeared due to changes in flow regimes caused by dams and diversions upstream (Ziewitz et al 1992, Sidle and Kirsch 1993). Wetlands throughout the Great Plains have also undergone considerable changes primarily due to basin drainage for agriculture (Skagen and Thompson 2005).

Many of the factors affecting piping plover reproductive success can be traced to degradation of habitat as a result of altered water flow regimes. These are discussed below in more detail, along with other threats to recovery.

\section{Water Flow and River Dynamics}

Water flow regimes throughout much of the interior U.S. differ greatly from historic regimes. Prior to anthropogenic alteration, the Missouri River was a dynamic, constantly changing ecosystem characterized by braided channels, sandbars and natural floodplain communities (USFWS 2003). Typically, the natural hydrologic cycle followed a double peaking regime corresponding with snowmelt and spring rains on the plains in March and April, and snowmelt from the Rockies in June (USACE 1997, USFWS 2003). July was characterized by receding water levels.

Following this bimodal flood pulse, an extended period of low flow from August through February occurred (Galat and Lipkin 2000). Under such natural river conditions, islands and sandbars were continually reshaped, created and destroyed by the rivers erosion and deposition processes (USFWS 1985). Periodic inundation due to natural water regimes also scoured sandbars and maintained plover nesting habitats that were relatively free of vegetation.

Beginning in the 1930s, impoundment of the Missouri River greatly affected natural hydrologic and geomorphic processes, resulting in altered water quality characteristics downstream. The Missouri Rivers flows below Fort Peck Reservoir are now highly regulated, with greatly reduced peak flood pulses and generally higher than pre-impoundment base flows (Power and Rychman 2000). In fact, the median high flow was cut in half following the dam's closure (Shields et al 2000). The result of these changes is an annual hydrograph that exhibits far less variability (National Research Council 2002).

Heese and Mestl (1993) reported that early operations of Fort Peck dam did not appear to affect the hydrograph and define the pre-regulation period for the whole river as 1929-1948. Utilizing these criteria, pre and post regulation hydrographs for the Missouri River, downstream of Fort Peck Dam, illustrate such changes in water flow (Figures 13 and 14). 


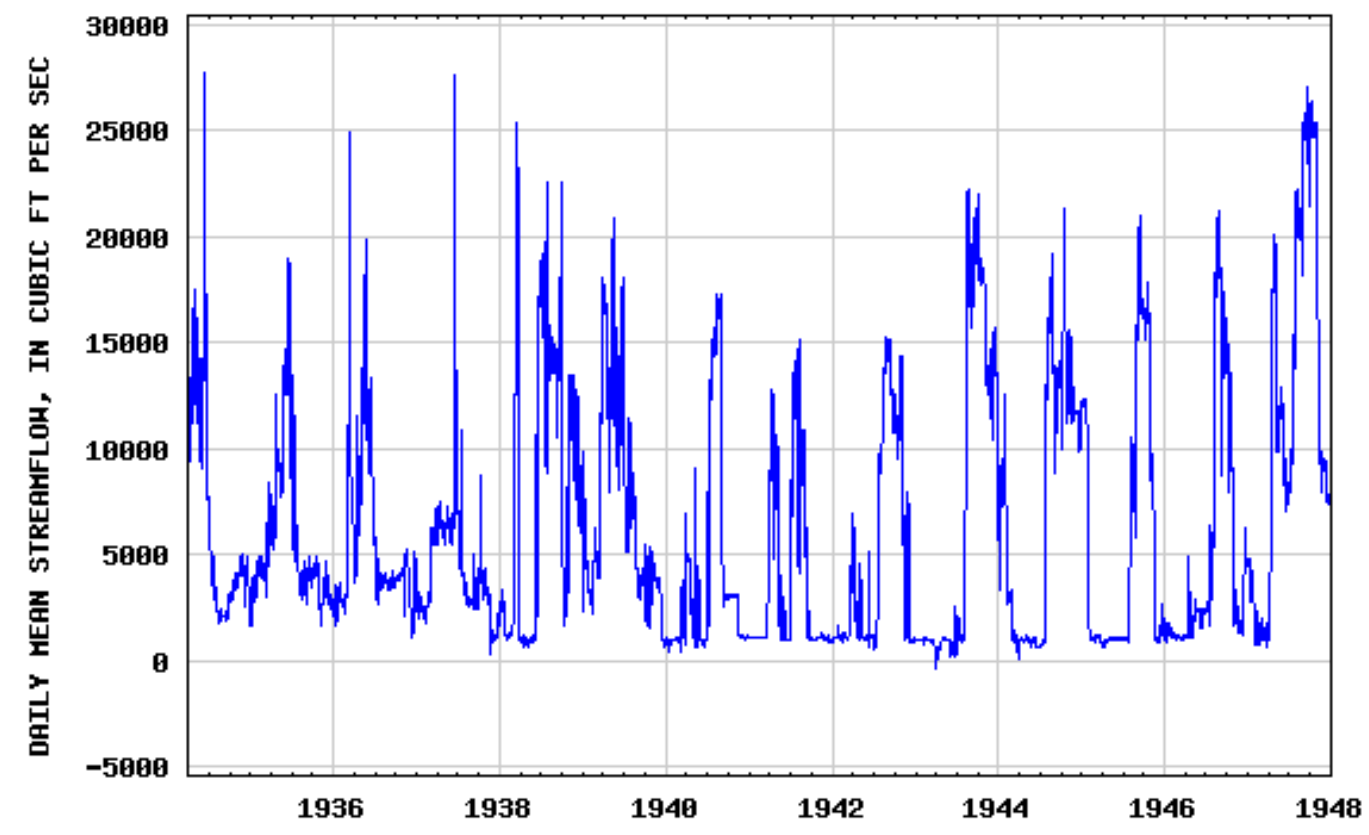

Figure 13: Pre-regulation hydrograph for Missouri River, below Fort Peck Dam, Montana (From USGS).

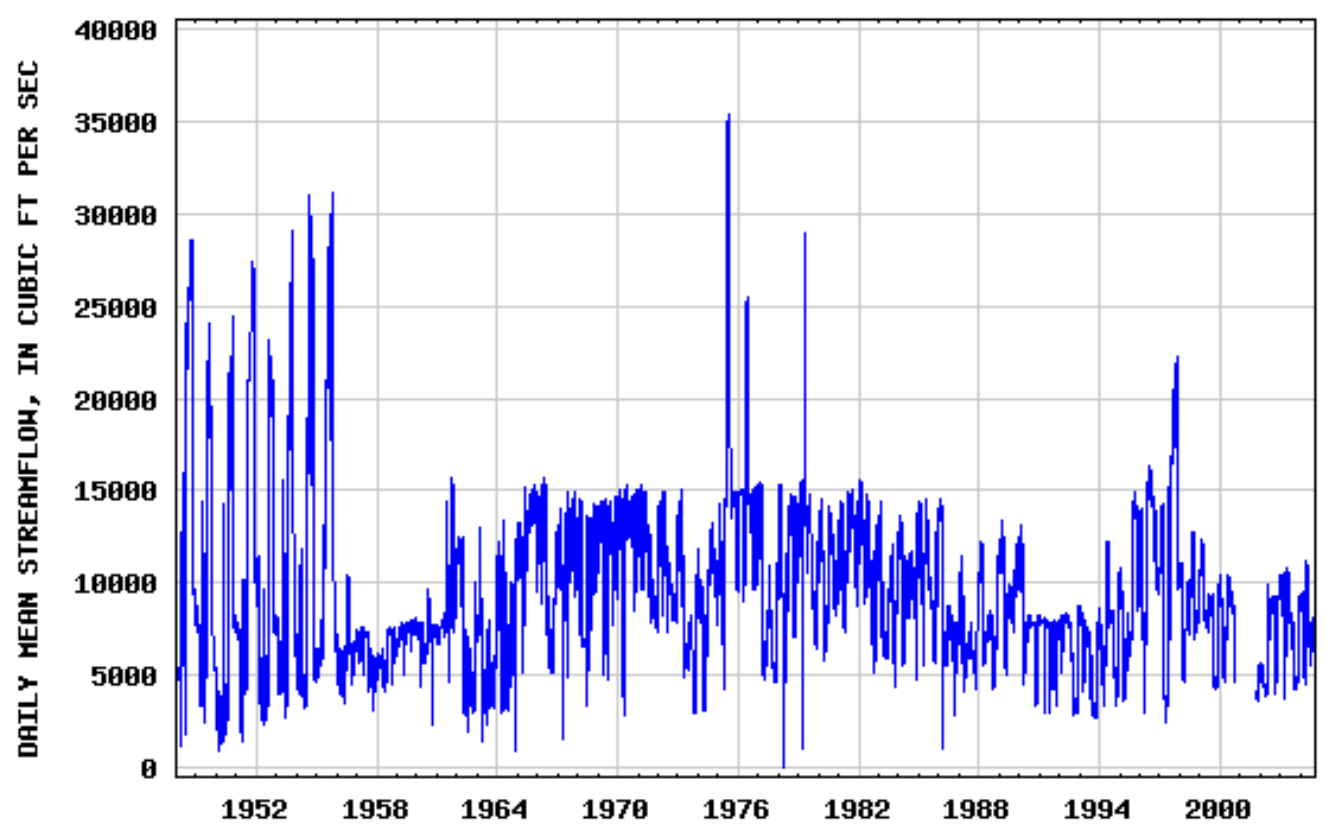

Figure 14: Post-regulation hydrograph of Missouri River, below Fort Peck Dam, Montana (From: USGS). 
In addition to alteration of the hydrologic cycle, discharge regulation and storage of flows along the Missouri have interrupted sediment and organic material transport (USFWS 2003), thereby altering many of the dynamic physical processes that maintain this large river ecosystem. Impoundment has contributed to degradation of the remaining sandbar habitat as sediment-poor water erodes islands without corresponding accretion elsewhere (National Research Council 2004). For example, from 19401952 (the period from closure of Fort Peck Dam until closure of Gavins Point Dam), the average annual sediment load transported past Omaha was 148,930,000 metric tons. After 1954, the average sediment load was reduced to $29,487,600$ metric tons (Slizeski et al 1982, National Research Council 2002).

Suppression of high spring flows, due to reservoir storage, has also led to vegetation encroachment and as a result much of the essential sandbar habitat is now unsuitable for nesting plovers. Below Garrison Dam, North Dakota, a lack of new alluvial deposits is reportedly leading to a floodplain forest of advanced successional stage (Johnson et al 1976). Consequently, piping plovers are often faced with finding a nest site outside the mid bar channel or not nesting at all (USFWS 1988).

\section{Unpredictable Water Levels (flooding)}

Fluctuating water levels have been postulated to be an important source of nest failure in the midcontinental plover population (Espie et al 1998). While natural flooding of nests and chicks has been reported on some river systems in the U.S. (Schwalbach 1988), human-induced water level fluctuations can also cause egg and chick mortality (North 1986, Schwalbach et al 1993).

Prior to dam construction, water flow patterns along main stem rivers were more predictable. After the spring peaks, river flows normally declined affording piping plovers the opportunity to nest as water levels receded and sandbars became available (USFWS 1988). Today rivers are managed for flood control, navigation and hydroelectric power. As a result, inappropriately timed water releases may cause periodic inundation of sandbars, which can prove lethal to piping plovers if water discharge takes place during nesting or prior to fledging. For example, plover egg (nest inundation) and chick (stranding) losses below dams may occur after water held back to minimize flooding downstream is subsequently released (USFWS 2003). In fact, sustained reservoir releases during the naturally low-water season cause protracted flooding of about two-thirds of the Missouri River and may be as damaging a disturbance to the river biota as reduction of the annual June flood pulse (Galat and Lipkin 2000).

Rapidly rising water levels at reservoir sites have also played a role in limiting reproductive success. At Lake Diefenbaker, Saskatchewan, researchers determined that the major reduction in fledging success between years was largely due to flooding of nests before eggs hatched (Espie et al 1998). In Montana, the Missouri River is subject to USACE water level regulation policies. Accordingly, lower lying nest sites along the Missouri River, below Fort Peck Reservoir, and along the shores of Fort Peck Reservoir, may be subject to rapid flooding and inundation. Thus, while flooding is potentially problematic at both river and reservoir sites, it does not appear to be a significant problem at alkali lake sites in Northeast Montana (M. Rabenberg, pers. comm.). 


\section{Food Availability}

Limited information on piping plover foraging ecology and diet composition exist, but researchers are beginning to examine the relationships between river hydrology, invertebrate abundance and piping plover productivity (C. Kruse, pers. comm.). Along the Missouri River, biologists suspect that unfavorable water temperatures below main stem dams may affect productivity by lowering invertebrate production. Preliminary results indicate that invertebrate numbers downriver from cold water release dams are lower than those found in other habitats in the region (Danielle Le Fer, pers. comm.) and differences in prey availability are reflected in chick growth rates and probability of survival.

Furthermore, analysis has shown that chick growth rates downstream of warm water releases are higher than at sites characterized by hypolimnetic releases.

For many shorebird species, chick growth rates and mass gains are affected by food supplies (Loegering and Fraser 1995). A lack of food resources may slow or limit development (O'Connor 1977) to the point that chicks that fail to gain mass above certain thresholds do not survive (Loegering and Fraser 1995). Although anecdotal, biologists working with piping plovers along the Missouri River have noted disparities in both the timing and rate of fledging. Prior to the floods of 1995-1997, emaciation of chicks was seen and they commonly required 28-32 days to attain fledgling status (C. Kruse, pers. comm.) compared to 18-20 days at alkali lake sites (M. Rabenberg, pers. comm.). Following these high water years, hatch rates and fledging rates increased significantly (USFWS 2003) while chick fledge times decreased to approximately 22-25 days (C. Kruse, pers. comm.). Moreover, corresponding changes in the occurrence and nature of sandbar complexes resulted in a significant increase in the amount of forage rich, edge habitat (USFWS 2003).

In Montana, although plovers are recorded along the Missouri River, very few have been recorded west of Wolf Point (approximately 112 km/70 miles east of Fort Peck Dam). While plover nesting habitat availability is poor along this stretch (USFWS 2002), it is possible that invertebrate production is being affected by hypolimnetic releases below Fort Peck Dam. Research conducted by MFWP biologists between April and November 2004, revealed that average daily water temperature below Fort Peck was significantly lower $\left(12.3^{\circ} \mathrm{C}\right)$ than that recorded upstream of the dam $\left(17.6^{\circ} \mathrm{C}\right)$ (Figure 15).

More importantly, maximum water temperature (attained during the summer months) was suppressed $10.4{ }^{\circ} \mathrm{C}$. Mean daily water temperature did warm longitudinally from below Fort Peck Dam to the lowermost Nohly site $\left(15.8^{\circ} \mathrm{C}\right)$, but mean daily water temperature at Nohly was significantly less than above the dam (D. Fuller, pers. comm.). As a consequence, the thermal impacts of cold hypolimnetic releases from Fort Peck Dam remained evident $280 \mathrm{~km}(174 \mathrm{rm})$ downstream from Fort Peck Dam. In fact, natural water temperatures were only restored where the Missouri River met the Yellowstone River at the Montana-North Dakota border.

Although speculative at this time, there is growing evidence to support the hypothesis that alteration of the natural flow regime may significantly impact piping plover productivity. Moreover, the ensuing cold water releases from mainstem dams, such as Fort Peck, during summer months, may impact food availably, productivity and reproductive success. 


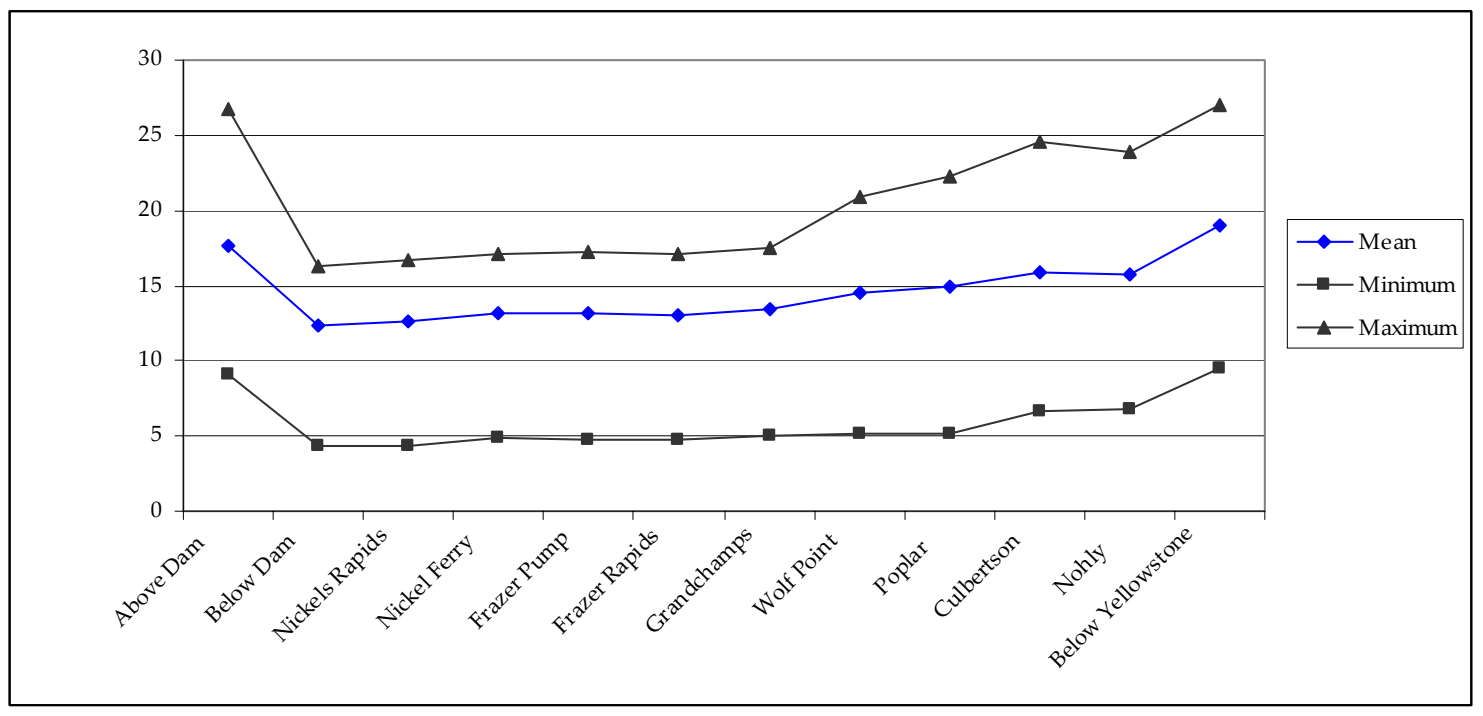

Figure 15: Mean daily water temperature $\left({ }^{\circ} \mathrm{C}\right)$ for Missouri River mainstem locations in 2004 Data from MFWP, D. Fuller pers. comm.

\section{Alkali Wetland Loss and Modification}

Habitat loss and degradation are often cited as contributing factors in piping plover declines but until recently they had not been quantified at alkaline wetlands (Root and Ryan 2004). While these habitats may not have experienced the levels of degradation observed at riverine sites, smaller wetlands throughout the Great Plains have undergone considerable changes in the last 50 years (Dahl 1992) primarily due to basin drainage for agriculture (Skagen and Thompson 2005). Furthermore, many of the biotic (large grazing ungulates) and abiotic (fire) disturbances that shaped the natural landscape have been eliminated (Root and Ryan 2004). While cattle affect vegetation structure and composition and are present in many areas, landscape use is undoubtedly different to historic times: many areas are now cultivated for crops.

Many wetlands within the Prairie Pothole Region are embedded within an agricultural landscape and the landscape surrounding these aquatic habitats can exert a profound effect on their functioning (USDA 2002). While habitat loss obviously occurs through direct conversions, such as draining and filling, agricultural practices may indirectly degrade remaining wetlands (National Research Council 2001). Moreover, elevated sedimentation rates (Martin and Hartman 1986, Gleason and Euliss 1996), drift of agricultural chemicals into wetlands (Grue et al 1989), excessive inputs of nutrients (Neely and Baker 1989), unnatural variance in water-level fluctuation (Euliss and Mushet 1996), and altered vegetative communities (Kantrud and Newton 1996) have all been linked to cultivation practices (Euliss et al 1999).

Grassland habitats historically protected prairie soils from erosion and moderated surface runoff (Glessen and Euliss 1998). Cultivation of upland sites has, however, greatly affected natural hydrologic processes, resulting in accelerated erosion and sediment deposition into basin wetlands (Martin and Hartman, 1986; Gleason and Euliss 1996). For example, Gleason (1996) and Gleason and Euliss (1996) determined that sedimentation rates and the inorganic fraction of sediment entering wetlands were significantly higher in 
wetlands with cultivated catchments than in wetlands with grassland catchments. In fact, sedimentation rates are often orders of magnitude higher than in natural landscapes (Gleason and Euliss 1998, Gleason et al 2003). Sedimentation from anthropogenic sources not only reduces water storage volume and the topographic life of prairie wetlands (Gleason and Euliss 1998), but changes vegetation structure and diversity surrounding the wetland (Gleason et al 2003). Furthermore, sediment derived from upland sites may cover up coarser gravel substrates located on historic nesting beaches. Thus, excessive sediment input from agricultural soils has the potential to alter alkali wetland sites used by plovers during the breeding season.

Agricultural activities on uplands that surround prairie wetlands have also impacted and altered aquatic invertebrate communities (Euliss et al 1999) that plovers depend on. Drift of agrichemicals causes direct invertebrate mortality (Euliss and Mushet 1999, Gleason et al 2003), while increases in sedimentation and siltation obstruct invertebrate filter feeding apparatus and bury invertebrate eggs (Glesson and Euliss 1996). Furthermore, investigations show that invertebrate abundance has been affected. For example, Euliss and Mushet (1999) found that Cladocera ephippia were less abundant in the tilled basins of temporary wetlands in agricultural fields compared to wetlands in grassland landscapes with no prior tillage history.

In addition to the effects of sediment load on plant and invertebrate assemblages, research also suggests that hydrologic fluctuations are more variable in altered landscapes. Euliss and Mushet (1996) measured water-level fluctuation in temporary, seasonal, and semi-permanent wetlands distributed among landscapes dominated by tilled agricultural lands and those dominated by grassland. Fluctuations were greater at wetlands in areas of intensive agricultural activity relative to those in more natural grassland settings. Temporary and seasonal wetland sites also exhibited substantial hydrologic fluctuations compared to semi-permanent wetlands. While such sites are not usually used as nesting habitat, they may provide foraging sites if located in close proximity to larger more permanent wetlands (M. Rabenberg, pers.comm.). It is possible, therefore, that particularly during drier climatic periods, seasonal wetlands embedded within agricultural fields may not provide adequate habitat for breeding plovers. Furthermore, drainage of upland wetlands may well affect seepage flow to remaining lower lying wetland sites, resulting in altered historic water depths and hydroperiods.

Studies of piping plover habitat availability also suggest that changes in vegetation structure have occurred at alkali wetland sites not subject to intense agriculture. Working with historical aerial photographs, Root and Ryan (2004) measured vegetation changes at two North Dakota alkaline wetland complexes between 1938 and 1997. Although comparisons of overall beach habitat availability were confounded by variations in water levels caused by seasonal and multi-year water level changes, the authors documented persistent losses of important upper-beach nesting habitats due to vegetation encroachment. The virtual elimination of fire in this ecosystem as well as reduced livestock grazing intensity has quite possibly reduced vegetation disturbance and allowed increased growth (Root and Ryan 2004). Likewise, in Alberta, during the 2001 International Piping Plover Census, vegetation encroachment was identified as a potential threat on over $41 \%$ of all lakes surveyed and on $52 \%$ of lakes with plovers (Prescott 2001). 
As alkali wetland habitats have traditionally supported $60-78 \%$ of plover breeding pairs in the Great Plains (Plissner and Haig 2000), such trends could be detrimental to overall plover productivity. Although nest predation is assumed to be the primary limiting factor to plovers in this region (USFWS 1988, Goossen et al 2002, Larson et al 2003), changes in wetland hydrology (Euliss et al 1999), sedimentation rates (Gleason and Euliss 1998, Gleason et al 2003), invertebrate abundance (Euliss and Mushet 1999) and vegetation structure (Root and Ryan 2004), may be critical to long-term population recovery.

\section{Predation}

While plovers have evolved with predation pressures and some loss due to predation is expected even in unaltered systems, human encroachment and management operations may exacerbate the situation. In addition to direct flooding of nests, river level fluctuations also influence the degree of predation a colony site experiences (USFWS 2003). While nest sites on channel sandbars that remain isolated from the main shoreline are less susceptible to mammalian predators, studies suggest that flooding of river sandbars during the nesting season increases the incidence of predation (Schulenburg and Schulenburg 1982, USFWS 2003). Rising water levels shrink the limited available habitat leaving chicks and eggs more vulnerable to predators.

Along the Missouri River in South Dakota, predation was reported as the leading cause of nest and chick loss (Kruse et al 2001). Primary nest predators identified included American crow (Corvus corvus), raccoon (Procyon lotor) and mink (Mustela vison), while American kestrel (Falco sparverius) and great horned owls (Bubo virginianus) were responsible for the majority of chick losses. The authors suggest that the high predation rates observed were a direct result of sandbar habitat deterioration and the resulting increase in predator foraging efficiency (Kruse et al 2001). Furthermore, as high spring flows have the potential to flood predator den sites along the Missouri, a reduction in the frequency, duration and magnitude of high spring flows could lead to artificially elevated predator numbers.

At alkaline wetland sites, predation of chicks and eggs is the primary threat facing breeding birds (Larson et al 2003). Changes in land use practices have redistributed predator communities and inflated local predator populations (Sargeant et al 1993). Consequently, species, such as plovers, that nest along shorelines may be exposed to a variety of predators whose populations are affected by humans. While the probability of fledging chicks apparently increases when conspecifics nest in close proximity (Haig 1987, Knetter et al 2002), Mayer (1991) determined that reproductive success was negatively correlated with piping plover nesting density. Predation rates of eggs and chicks increased significantly at beaches with higher plover densities. Presumably, limited nest site availability concentrates breeding birds making them more vulnerable to predation.

Predation can dramatically suppress productivity: in North Dakota, predation was responsible for 89$95 \%$ of egg failure in two consecutive years (Prindiville 1986), while $48 \%$ to $70 \%$ of egg failures and $69 \%$ of chick mortalities were recorded in Minnesota (Wiens 1986). As a result, substantial effort has been invested in controlling predation (Figure 16). Nest protection studies conducted on Missouri Coteau alkali lakes in northwestern North Dakota and northeastern Montana reported mean fledge ratios increasing from 1.05 chicks per pair to 1.20 chicks per pair (Knetter et al 2002). Likewise, utilizing 
published and unpublished data for the Great Plains region, Larson et al (2002) estimated that fledging success increased from 0.89 to $1.15-1.25$ with predator exclusion. This has not been the case in all areas, however. While cages appear to increase plover reproductive success on prairie alkali lakes, regional differences in predator community compositions influence their effectiveness (Murphy et al 2003). In addition, adult birds may be more vulnerable to predation within exclosures (Murphy et al 2003) and many studies strongly urge managers to evaluate the risks, especially in areas where there is a history of adult plover depredation (Knetter et al 2002, Murphy et al 2003).

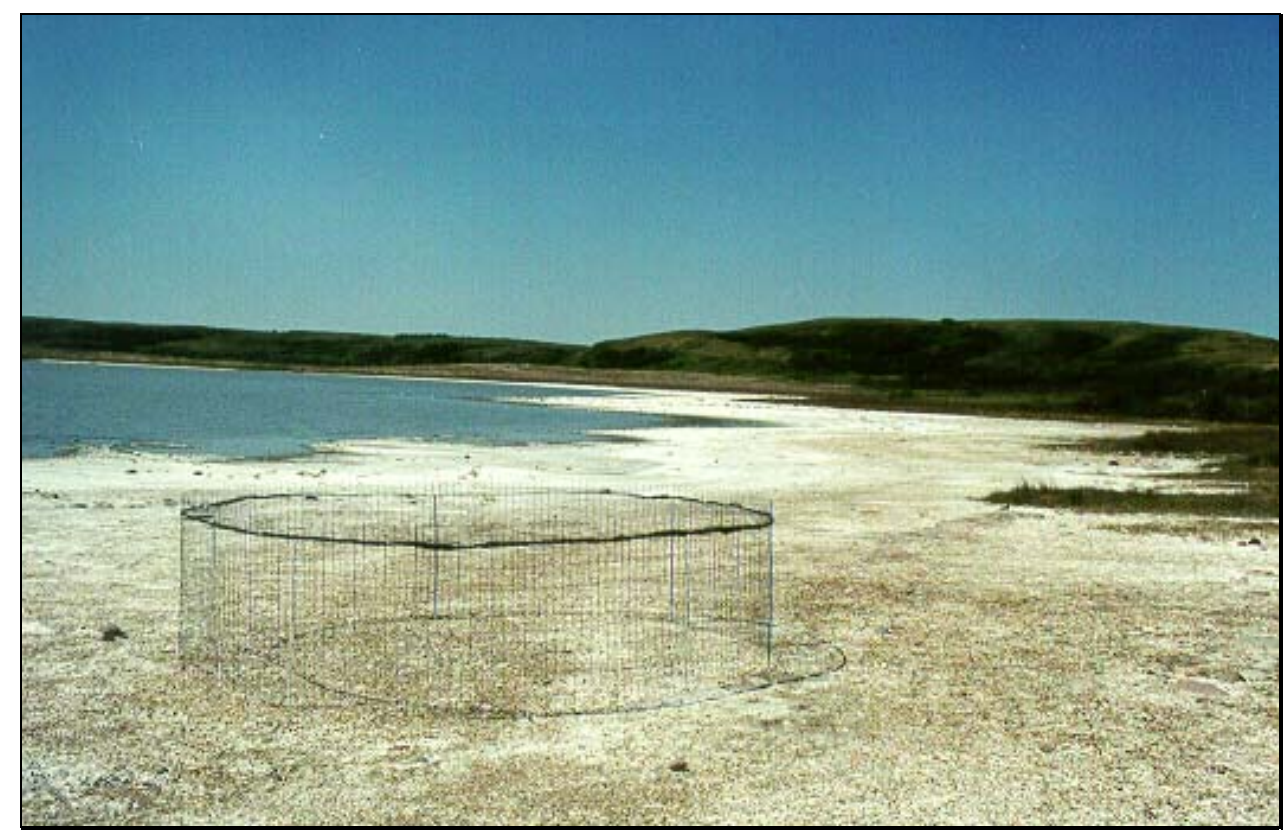

Figure 16: Exclosure protecting piping plover nest at alkali lake, North Dakota Photo Courtesy: Adam Ryba.

\section{Livestock}

Livestock disturbances pose a threat and have the potential to limit reproductive success through trampling of eggs and/or direct chick mortality (USFWS 1988). At alkali wetlands, however, disturbances are more likely to result in indirect effects. Breeding birds may abandon nests or simply avoid areas during years when cattle are present (Smith et al 1993). If the substrate is soft, livestock disturb nesting substrates by leaving deep tracks in the shorelines that can potentially trap plover chicks. Shorelines subject to such disturbance are also more prone to vegetation establishment and such herbaceous growth can become an effective corridor for predators (USFWS 1988). On gravelly beaches, however, Smith et al (1993) reported no such hoof prints and propose that livestock grazing could be cautiously employed after the plover nesting season as a means of reducing vegetation encroachment. In fact, the benefits of grazing upland sites surrounding alkali lakes may well outweigh many of the negative effects and some managers now employ judicious use of grazing to manage vegetation growth (M. Rabenberg, pers. comm). 


\section{Human Disturbance}

Human disturbance, both direct and inadvertent, continues to pose a problem on the Atlantic coast (Strauss 1990) and may be a contributing factor in other areas of the piping plovers breeding range. The presence of people, pets or vehicles in the vicinity of nest sites may result in the unintended crushing of nests (Strauss 1990) or simply inhibit territorial establishment and courtship. In addition, breeding birds may be reluctant to return to the nest, leaving eggs and/or chicks vulnerable to temperature fluctuations.

Vehicular and other recreational activities are widespread along parts of the Platte and Missouri Rivers and such activities occur predominantly on barren islands (USFWS 1985) that are favored by piping plovers. Likewise, all terrain vehicle (ATV) disturbances pose a threat and have the potential to impact piping plover reproduction. At alkali wetland sites in North Dakota, for example, nests on territories that showed evidence of ATV disturbance exhibited lower success rates than nests on undisturbed territories (Prindiville-Gaines and Ryan 1988).

As birds nesting in areas frequented by humans often suffer from disturbance, management activities also pose a potential threat. Conservation efforts, including activities such as protection of nests from predators or people, censuses of breeding pairs,

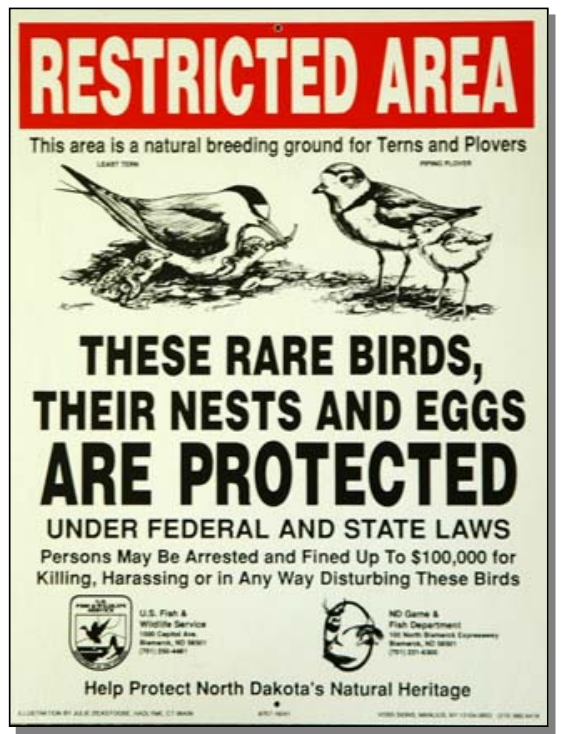

Figure 17: Plover and Tern Signage monitoring of nest success and banding studies all have the potential to disrupt breeding. Along the Atlantic seaboard, MacIvor et al (1990) found that research activities did not increase nest predation by red foxes (Vulpes vulpes). In Atlantic Canada, however, there are reports of raccoons and crows following a researcher's tracks to plover sites that were under observation (Goossen et al 2002). In addition weed control activities on sandbars or along stretches of shorelines could result in disturbance if undertaken during critical nesting periods.

\section{Infectious Disease}

Population impacts as a result of disease are most likely to have deleterious effects on small populations with limited distributions. Diseases, such as West Nile Virus (WNV), Avian Influenza and Avian Cholera, have the potential to impact piping plover populations. While little information exists for the species, a dead piping plover, located on Lewis and Clark Lake, South Dakota, tested positive for WNV in 2003 (USGS 2003, Aron 2005). Furthermore, in 2005, the USGS National Wildlife Health Center listed piping plovers as a WNV susceptible species (USGS 2005).

\section{Pollution and Environmental Contaminants}

Piping plovers feed at relatively high trophic levels and as a consequence may be susceptible to the effects of bioaccumulation from contaminants such as organochlorine pesticides, heavy metals and polychlorinated biphenyls (PCBs). This has the potential to negatively affect egg production, chick survival and overall reproductive success (Ohlendorf et al 1986, Hothern and Powell 2000) but little is known about the impacts in this species (Mierzykowski and Carr 2004). 
Mercury residues have been recorded in piping plover eggs gathered along the Atlantic coast, but concentrations were not elevated relative to embryotoxic thresholds (Mierzykowski and Carr 2004). Elevated levels of selenium have also been detected in piping plover eggs along the Platte River, Nebraska (Fannin and Esmoil 1993). While the precise tolerance of plover eggs to selenium toxicity is unknown, all samples revealed levels higher than the upper normal boundary threshold ( $3 \mu \mathrm{g} / \mathrm{g}$ dry weight) reported for other species. Moreover, elevated levels may be causing embryo death without gross embryological defects. This study coupled with results from other toxicology work (Ruelle 1993, Welsh and Mayer 1993) indicates that contaminants could be accelerating population declines for piping plovers.

Along the Missouri River in Montana, plover nest sites are found below the confluence with the Milk River (USFWS 2002). They are also located at wetland sites within the Milk River Basin. Sampling conducted by the USGS has identified the Milk River Basin as a region susceptible to irrigation-induced selenium contamination. While selenium concentrations in eggs from various avian species were not found to be embryotoxic, sample sizes were small and not enough birds of appropriate feeding guilds were included (Seiler et al 1999). As selenium does not break down chemically once it enters an aquatic environment (Fannin and Esmoil 1993), plovers nesting downstream could potentially be impacted.

Industrial disturbance (construction, installation and maintenance), as a result of fossil fuel extraction, around plover breeding sites has the potential to pollute water and shorelines, deplete water levels, and eliminate surrounding vegetation (Wersher 1992, Prescott 1997). The direct impacts of oil and gas development on plover habitat are not well documented, but changes in water chemistry and beach substrates attributed to potassium sulfate development have been observed at several breeding locations in Saskatchewan (Wershler and Wallis 1987, Precott 1997).

Within Sheridan County, large concentrations of oil and gas wells, together with their associated tank batteries and produced water pipelines are common. Adverse effects from environmental contaminants generated in conjunction with such exploration and production include drilling muds, produced water and production activity wastes (EPA 2000, Nelson 2006). Produced waters are characteristically high in salts and an influx of salts to wetlands has the potential to impact invertebrate production. In addition, pipeline leaks and spills often result in wetland sites characterized by denuded vegetation and a sterile aquatic environment (Nelson 2006).

As many piping plover sites located in northeast Montana currently have oil and gas installations within close proximity, such developments are a potential threat to breeding habitat. In fact, fourteen Waterfowl Production Areas (WPAs) in Sheridan County have gas well installations on site and a further 16 are located within one mile of such operations. In addition, on site disturbance as a result of elevated human activities may exacerbate the situation.

\section{Nesting and Reproductive Success}

Many factors highlighted in the preceding sections, such as habitat loss and degradation, altered water flow regimes, predation, and human disturbance, affect piping plover nesting and reproductive success (USFWS 1988, USFWS 2003). More specifically, data suggests that reproductive success of plovers is 
highly variable among sites and years and appears to be influenced primarily by annual hydrologic patterns (water-flow regimes) in combination with predation pressures (National Research Council 2004).

Several PVA analyses of piping plovers have been undertaken to estimate mean reproductive success and survival rates required to stabilize the population or increase it to levels identified in the Recovery Plan (USFWS 1988). Using an adult survival rate of $66 \%$, and a juvenile rate of $60 \%$, Ryan et al (1993) determined that a mean fecundity rate of 1.13 fledgling per pair of adults was required to maintain a stable population size for the Great Plains. Annual population increases of $1 \%$ and $2 \%$ required 1.16 and 1.19 chicks per pair respectively (Ryan et al 1993). Using a metapopulation approach, in which both the Great Lakes and Great Plains birds were considered spatially distinct, but interconnected, Plissner and Haig (2000) estimated that a mean reproductive rate of 1.25 fledged per pair per year was necessary for the population to persist in the short term. Even so, numbers of individuals would ultimately decrease substantially without higher fecundity levels.

Both models were, however, sensitive to adult survivorship and in 2000, revised estimates of adult survivorship (73.7\%) were published based on banding studies (Larson et al 2000). Using these estimates, recent PVA models predict that a population-wide fledging rate of 1.10 is needed to stabilize the mean of simulated populations in the Great Plains (Larson et al 2002). Under this scenario, the probability of continued population decline is however much greater than $50 \%$. To stabilize the median size of simulated populations (i.e. to reduce the probability of continued decline to $\leq 50 \%$ ) required a fledge ratio of 1.25 pairs across the whole population. In light of such studies, the USFWS revised earlier estimates, established a system-wide fledge ratio goal of 1.36, and directed the USACE to maintain specific fledge ratios for all areas on the Missouri River; namely Fort Peck River 1.33, Garrison 1.18, Fort Randal 0.92 (USFWS 2003).

Although not referred to as frequently in the published literature, clutch size is also an important component of reproductive fitness because it directly affects reproductive success in any breeding season. The availability and quality of food has been shown to affect clutch size in closely related species (Burger et al 1994) and differences in both, preceding the egg laying period, may be a proximate cue by which birds reduce their clutch size (Murray 1985). Thus, regional differences in clutch size may reflect differences in food availability (Burger et al 1994). Given that invertebrate abundance downriver from cold water release dams on the Missouri River is poorer than in other areas (USFWS 2003, C. Kruse, USACE, pers. comm., D. Le Fer, pers. comm.) it is possible that clutch size, and hence reproductive success, for piping plovers could be affected by foraging success and prey availability.

\section{Factors Affecting Piping Plover Productivity in Montana}

Piping plovers utilize several habitat types in Montana, each with a unique set of limiting factors. Identifying such factors and directing appropriate management actions is critical to aiding recovery efforts. Along the Missouri River, productivity monitoring of both riverine and reservoir habitat, conducted between 1993 and 2005, identified 90 piping plover nest sites, of which 51 hatched. Of the remaining nests $(n=49)$ the outcome of $33 \%$ could not be determined (Table 9). From a conservation perspective, this is potentially problematic: this category accounts for the second largest number of potential nest failures. 
Excluding nests that were abandoned $(n=5)$ or whose fate was unclear $(n=16)$, flooding accounted for the highest number of known nest failures. Rising lake levels, as a result of USACE operations, led to the destruction of $63 \%(n=14)$ of all destroyed nests at Fort Peck Reservoir. While flooding resulted in the loss of only three nests along the Fort Peck river reach, fluctuations in water releases may be additive to extreme weather (rain, wind storms, wave action) problems. Of those nests destroyed by rising water along the river reach however, only one could be directly attributed to USACE operations (G. Pavelka, pers. comm.). Predation caused $6 \%$ of nest failures. Unlike many areas in the Missouri River drainage, livestock and human disturbance does not appear to be a major threat along the Missouri River, below Fort Peck Reservoir, or along the reservoir shoreline.

Table 9: Causes of piping plover nest failures along the Missouri River, Montana, during USACE monitoring period 1993-2005. Includes Fort Peck Reservoir and Fort Peck River Reach. Data from USACE, G. Pavelka, pers. comm.

\begin{tabular}{|c|c|c|c|c|c|c|c|}
\hline Cause & Flood & Weather & Predation & $\begin{array}{c}\text { Bank } \\
\text { Erosion }\end{array}$ & $\begin{array}{c}\text { Human } \\
\text { Disturbance } \\
\text { \& Livestock }\end{array}$ & Unknown ${ }^{* *}$ & Abandoned \\
\hline $\begin{array}{l}\text { Number } \\
\text { of Nests } \\
\text { Destroyed } \\
\end{array}$ & 17 & 5 & 3 & 1 & 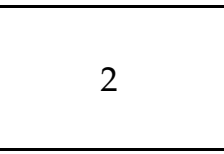 & 16 & 5 \\
\hline $\begin{array}{l}\text { As a \% of } \\
\text { nests that } \\
\text { failed to } \\
\text { hatch }\end{array}$ & $35 \%$ & $10 \%$ & $6 \%$ & $2 \%$ & $4 \%$ & $33 \%$ & $10 \%$ \\
\hline $\begin{array}{l}\text { As a \%of } \\
\text { all nests } \\
\text { identified }\end{array}$ & $18.9 \%$ & $5.6 \%$ & $3.3 \%$ & $1.1 \%$ & $2.2 \%$ & $17.8 \%$ & $5.6 \%$ \\
\hline
\end{tabular}

Annual piping plover surveys have been conducted in Sheridan County at the Northeastern Montana WMD and Medicine Lake NWR since the late 1980s but productivity data have not been gathered consistently. Between 1994 and 1997, annual nest success of unmanaged (i.e. no cages) plover nest sites at these sites, coupled with data from nests at alkali wetland sites in northwestern North Dakota, averaged $38 \%$ (Murphy et al. 2000). While causes of nest loss were poorly understood, the authors speculate that most were probably due to depredation.

Consistent annual productivity monitoring began in 1996 (A. Ryba, pers. comm.) and management efforts have focused on recording numbers of breeding birds, identifying nest sites, erecting predator exclosures and determining fledging rate. Information from annual reports suggests that predation and livestock disturbance pose the greatest threat to reproductive success in this region, although the specific cause of nest losses are generally unknown (Ryba 2004, 2005). Despite such uncertainty, nest success is higher today: in 2005, apparent nest success in the Northeast Montana WMD was 75.6\%. 
Although specific causes of egg and chick loss at alkaline wetlands in northeastern Montana is poorly documented, predator exclusion has dramatically increased reproductive success. Data collected in the 1990s, and compiled by Larson (2002), show that fledge rates in the Montana-North Dakota alkali lakes complex increased from 0.89 fledglings per pair of breeding adults, without predator exclusion, to 1.46 when nest cages were utilized. Reproductive success increased to 2.09 when piping plover nests were protected with both nest cages and temporary electric fencing. In addition, terrestrial predators account for the majority of egg and/or predation episodes while avian predators are primarily responsible for chick and adult losses (Ivan and Murphy 2005).

Detailed productivity data for breeding sites in Phillips County is lacking. Annual reports indicate however, that nest inundation, as a result of Bureau of Reclamation (BOR) water management policies, and predation pressures may impact plover survival (Montana Piping Plover Recovery Committee 1997). In prior years, rising water levels throughout the nesting season at Nelson Reservoir necessitated nest relocations (Prellwitz et al 1995) and both avian and mammalian predators were implicated in several nest losses.

Fledge ratios within the State of Montana fluctuate substantially between years and sites. Productivity data, gathered during the past ten consecutive breeding seasons for northeastern Montana (alkaline wetlands) show a mean fledge ratio (1.28 fledgling/pair of adults) that exceeds that required to stabilize the population in the Great Plains based on recent population viability analyses (Larson et al 2002). Similarly, along the Fort Peck River reach of the Missouri and at Fort Peck Reservoir, ten-year average fledge ratios, are relatively high. Both indices surpass that required for population maintenance in the Great Plains (Larson et al 2002) and are higher than the ratio called for in the USFWS Biological Opinion for the Missouri River (USFWS 2003). Population numbers at riverine sites are however relatively small, particularly at Fort Peck Reservoir, and as a consequence have the potential to skew fledge ratios.

\section{CONSERVATION AND MANAGEMENT CONSIDERATIONS}

As a state, Montana provides a diverse array of habitats for breeding plovers. Although the proportion of breeding birds recorded in recent years (7\% in 2001) has declined relative to states such as North Dakota, Montana has traditionally supported a sizable segment of the U.S. Northern Great Plains population (15\% in 1991). The peripheral nature of Montana relative to the overall breeding range of plovers, coupled with tremendous fluctuations in habitat availability between years at the landscape level most likely influences the number of birds that arrive at breeding grounds in any given year. Despite such variation, monitoring efforts conducted over the past decade indicate that the state has met its recovery goal of 120 birds (60 breeding pairs).

In light of the species dispersal response to spatial and temporal variations in habitat availability, what appears more noteworthy, is the potential resource Montana's wetlands and reaches of the Missouri may provide to breeding birds during years characterized by abnormal weather and water conditions elsewhere. In order to support national recovery objectives, critical habitat has to be maintained and restored throughout the birds breeding range. While population levels are not directly related to the amount of suitable habitat present (Haig and Plissner 1993), the value of maintaining such habitat in Montana was highlighted during the 1997 breeding season. Inundation of breeding areas further south 
resulted in increases in the number of breeding birds recorded on the Fort Peck River reach and at Missouri Coteau wetlands in the northeastern part of the state. Without such habitat, plovers migrating northward in search of suitable nesting sites may have failed to secure nest sites. Many of the management recommendations focus, therefore, on the necessary actions needed to maintain and/or restore critical breeding habitat at the landscape level. In addition, habitat specific enhancement strategies, aimed at increasing reproductive success, are proposed.

\section{General Management Concerns and Recommended Actions}

1. Standardization of monitoring techniques and data collection

Piping plover monitoring and breeding surveys within any given state or river reach may be conducted by NGOs, numerous state and federal resource agencies, as well the USACE, and each utilize different monitoring protocols. A lack of standardized monitoring techniques, coupled with varying amounts of coordination between agencies makes it difficult to interpret the range-wide population status of the piping plover during years when an international census is not being conducted.

Although fiscal restraints often determine the type and frequency of survey conducted, standardized procedures for data collection may ultimately increase the accuracy and efficiency with which data are gathered and allow for comparisons between sites and regions. Where possible, data gathered using standardized data forms and survey methods should be used e.g. how birds should be quantified (number of pairs, nests, or individual birds), how predation indices are calculated. Comparative standardized data on nest success, including nest fate and causes of nest failure, would help evaluate population health and reproductive success. In addition, accumulated observational data of piping plovers needs to be entered into a centralized regional database at the end of each field season. Such a database would ensure that critical data is maintained and accessible to managers while implementing recovery efforts.

Montana should continue to participate in the international range wide survey every five years by conducting censuses of all known and potential piping plover breeding sites (Appendix 4). In addition, established monitoring programs within the state should continue on an annual basis.

\section{Integrating plover management with local, regional and national initiatives}

Piping plover management should continue to be integrated into public-private partnership efforts, or joint ventures, as this may well provide an efficient mechanism for achieving regional conservation goals. Examples include the Prairie Pothole Joint Venture, Ducks Unlimited and the North American Waterfowl Plan. In addition, federal and district programs, such as Partners for Fish and Wildlife, the North American Wetland Conservation Act and the recently reauthorized Environmental Quality Incentives Program (EQIP), administered by the USDA Natural Resources Conservation Service (NRCS), should be incorporated into plover habitat restoration and management whenever possible.

Continued emphasis should be placed on improving collaborative working relationships with private landowners, wetland restoration projects, procurement of grassland easements, and implementation of grazing schedules. Landowners interested in protecting wetland habitat or surrounding uplands may be 
able to enter into cooperative agreements and cost sharing programs that allow them to restore native grasslands and improve the integrity of wetland sites.

\section{Landscape level habitat management}

While landscape level habitat management is currently being initiated at prairie Coteau sites in North Dakota and northeastern Montana (Adam Ryba, pers. comm.), local management initiatives in some regions focus specifically on individual wetlands. Research suggests, however, that breeding birds use a complex of sites, shifting between them as conditions change within or between years (Oring et al 2000, Skagen and Thompson 2005). It is recommended, therefore, that management efforts across the state focus at a broader landscape level.

Although efforts aimed at enhancing specific nesting sites are warranted, apparently suitable sites within a wetland complex may be overlooked. Managing a suitable mosaic of sites, including temporary to permanent wetlands and river sites, will provide a variety of options for migrating birds that will likely assure availability of habitat under any climatic condition (Skagen and Knorf 1994). GIS would provide a useful tool in initial efforts aimed at identifying and assessing the status of potential breeding habitats within a landscape level context (Phillips et al 2005).

\section{Assessment of wetland breeding habitat condition}

As a significant proportion of breeding plovers utilize alkaline sites (Haig et al 2005), managing critical wetland habitat to maximize productivity and survival is critical to long term recovery (Root and Ryan 2004). Since wetland condition is often determined by surrounding land use, it is recommended that the quality of all potential and existing sites be assessed at a landscape scale. Assessment using remote sensing, coupled with ground truth data, is needed to build a classification model that will aid in identification of potential sites and alteration in beach quality at known sites. Based on this information, piping plover habitat could be rated and recommendations for site protection or management actions prioritized. Data could also be utilized to assess the potential for population increase at both occupied and unoccupied nest sites. With this information, Montana will be in a stronger position to evaluate whether current management options are adequate to meet long term objectives.

\section{Restoration of wetland hydrologic and ecological processes}

Wetlands that are individually restored within a catchment that is still primarily in agricultural production may continue to experience degradation (USDA 2002). Thus, it is recommended that efforts aimed at restoring and protecting wetland function be undertaken. Restoration of upland wetland sites would act as a nutrient and sediment trap as well as potentially increasing the hydroperiod for lower lying wetlands. Seeding of tilled sites would also enhance functioning of lower lying wetlands by reducing the indirect effects associated with increased sediment loads. In addition, monitoring of temporary and seasonal wetlands, for potential changes in basin inorganic sediment levels and shifts in vegetation zonal patterns could be undertaken as a means of assessing degradation (USDA 2002).

\section{Predator management}

The range of species that prey on piping plover eggs and chicks varies spatially and temporally on alkali lakes in the northern Great Plains (Ivan and Murphy 2005). Investigations that focus on identifying site 
specific predators are required as implementation of appropriate predator control measures will be more cost effective and beneficial with such knowledge.

The use of predator exclosures placed over nests at breeding sites in the alkali lakes region have been successful at increasing reproductive success, and managers should continue to utilize them. Cages can, however, expose nesting adult plovers to predation (Murphy et al 2003). Accordingly, the extent and cause of adult predation needs to be determined, particularly with regard to the use of exclosures. In addition, communication with biologists from other Great Plains regions regarding cage design may be warranted. Biologists working in Alberta have reported success with newly developed small, portable cages: they appear be to less attractive as perches for raptors or rubbing posts for cattle (Alberta Piping Plover Recovery Team 2005).

Given that populations of several important avian predators have increased in Montana in recent years (Sauer et al 2001), reducing local abundance of predators such as large gulls (Larus spp.) and American crows (Corvus brachyrhychos) may also be warranted at some sites (Ivan and Murphy 2005). Furthermore, predator (avian and mammalian) habitat near wetlands occupied by plovers should be reduced: abandoned farm buildings, debris piles and shelter belts should be removed.

At this time predation does not appear to significantly impact plovers nesting at riverine sites in Montana. Predation management should therefore be undertaken on a site by site basis when appropriate. Suggested methods for controlling ground predators include elimination or relocation using live traps. If predation pressure intensifies at a particular site, predator exclosure cages should be considered. Strobe lights have also been used in other areas for nocturnal predators such as great horned owls (Bubo virginianus) and are an option if warranted (G. Pavelka, pers. comm.).

7. Managing water flow regimes in riverine habitats to simulate a natural hydrograph Ecologically based water flow management regimes often conflict with USACE management objectives (i.e. navigation, flood control, hydropower etc.), however, managed flooding along major rivers and their tributaries to mimic a more natural hydrograph should be considered. Naturalized flows, including increased spring flows and warm water releases, would clearly help restore aquatic habitats and their associated ecosystem processes, thereby lessening the negative effects associated with reduced annual flood pulses, poor forage availability, and increased water discharges during the plover nesting season.

Moreover, supporting data shows that high flows associated with naturally occurring high-water years (e.g. 1995 through 1997) created significant amounts of sandbar complexes and shallow water habitats necessary for plover nesting and foraging (USFWS 2003). For example, in the Gavin's Point reach of the Missouri suitable plover nesting habitat increased 13-fold between 1996 and 1998 (USFWS 2003). Restoring a more natural water regime that included a substantial spring pulse may reduce continual habitat loss due to erosion and vegetation growth.

\section{Preventing or reducing inundation of nests at riverine and reservoir sites}

Efforts should continue to be made to reduce untimely discharges of accumulated spring water from reservoirs during critical nesting periods. Moreover, as discharge volumes from mainstem dams are 
often calculated with little room for error, weather conditions should be monitored downstream and appropriate flood control actions taken to prevent the inundation of nests due to increased wave and wind action. Similarly, storm drainage discharges from tributaries feeding into mainstem river reaches should also be monitored to reduce the cumulative effects of high water levels, tributary inflow and wave action.

As reservoirs, such as Fort Peck, play a vital role in USACE flood management operations, plover breeding sites should continue to be identified and appropriate management action taken to prevent the inundation of nests if water levels behind dams increase. The same is recommended for sites in Phillips County (i.e. Nelson Reservoir).

\section{Vegetation encroachment}

Vegetation cover at potential riverine nest sites should ideally be no greater than $10 \%$ (Schwalbach 1988) and initiatives to reduce vegetation encroachment should be undertaken prior to the arrival of plovers. Water flow regimes that scour sandbars and islands may not be required on an annual basis but periodic "flood pulse" discharges should be undertaken to reduce vegetation encroachment. In addition, manually clearing sites should be evaluated as a possible management tool. If effective, breeding sites utilized in recent years could be maintained by clearing excessive vegetation prior to plover arrival in the spring. This could be undertaken either by physically removing vegetation or spraying with herbicides. However, based on USACE experience in 2005, remaining dead vegetation provides extensive predator perch sites and if vegetation is sprayed the capacity needs to exist to adequately remove it (Karen Kreil, pers. comm.).

Vegetation encroachment has also been documented at alkaline wetlands in North Dakota (Root and Ryan 2004) and Alberta (Prescott 2001). Consequently, research aimed at documenting vegetation succession at alkali sites needs to be undertaken. If widespread, management intervention may be required to provide adequate habitat availability to nesting plovers (Root and Ryan 2004). A combination of prescribed burns, salt application and herbicides could be used to achieve short-term vegetation reduction. In addition, after the plover nesting season, judicious use of livestock grazing, in areas with firm substrate (Smith et al 1993), should be considered, particularly in areas where prescribed burns are not permitted.

\section{Preserving suitable habitat in areas not currently utilized}

Clearly, suitable nesting habitat needs to be preserved throughout the piping plovers breeding range, not only to maintain the current range, but also to provide habitat when other areas are unavailable due to flooding (Kirsch and Sidle 1999) or drought. Such a strategy may ultimately reduce the risk of nest failure in any given breeding season. Directing habitat funding to maintain or secure easements along sections of river or at alkali wetland sites, including surrounding uplands, with consistent plover activity is recommended. River reaches and alkaline wetland sites not included in annual surveys may also provide additional potential plover nesting habitat. While managing wetland complexes is desirable, short term stop-gap measures aimed at preserving suitable habitat should be undertaken. If funding is available, surveys should be undertaken to identify and assess potential breeding sites. 


\section{Enhancing nesting habitat to increase available nest sites}

Habitat loss has been shown to cause a decrease in the number of nesting sites but an increase in nesting density along rivers. As large colonies may be more vulnerable to predation, efforts to increase the number of potential nest sites at river reaches may reduce vulnerability to predation. During annual surveys, identification of sandbars with likely nesting habitat along reaches should be recorded. If suitable foraging habitat exists within the immediate vicinity, habitat enhancement may be as simple as initiating vegetation removal to create potential nesting habitat.

Likewise, enhancing nesting habitat at alkaline wetland sites should be undertaken if warranted. Sites that have been utilized in the past could be restored through vegetation removal and/or addition of gravel substrate. Application of gravel to alkali beaches sites may provide short-term improvement, but it is critical, that if undertaken, gravel be hauled and spread during winter months when the ground is frozen. Failure to do so will likely result in deep vehicle ruts that may degrade potential habitat further. This management option should, however, be avoided at beach sites with soft substrate as vehicle tracks appear to develop even if application is undertaken during winter months (Smith et al 1993). Consequently, managers are urged to evaluate substrate type prior to hauling gravel.

\section{Livestock disturbance}

Disturbance of wetland beaches by livestock, which use them for loafing, to escape biting insects or as water sources (Goossen et al 2002), disrupts shorelines, churning up formerly packed gravel and alkali surfaces. The presence of cattle on alkali beaches with piping plover exclosures is also potentially problematic as they apparently utilize the structures as scratching posts. Efforts to ameliorate such situations should be undertaken.

Priority should be given to identifying grazing schedules, as this will afford managers the opportunity to remove cages on grazed land and/or determine whether erection of electrical fencing around predator exclosure cages is warranted. In addition, the establishment of alternative remote livestock water sources away from plover nesting habitat, coupled with deferred grazing programs, would reduce the impacts on breeding birds while maintaining the integrity of the wetland site. Where this is not feasible, easements or other agreements with private landholders could be established to allow fencing of plover nesting sites.

\section{Human disturbance}

At this time, human disturbance does not appear to dramatically impact plover reproductive success along either the Missouri River, or at Missouri Coteau wetland sites, in Montana. Systematic surveys of human activity should, however, be conduced to assess the level of activity that is occurring as well as the extent to which identified disturbances could potentially impact nest sites. If disturbance levels increase, to the point that they impact productivity, appropriate action should be taken.

Although the posting of signs at river access points and on nesting sandbars is an accepted technique, this has the potential to exacerbate problems in areas where people are hostile to endangered species protection. Likewise strict enforcement may be impractical due to fiscal constraints. Consultation with regional biologists and law enforcement officials will most likely prove more valuable in determining the 
appropriate action at a site should disturbance become a problem. For example, one-on-one contact with sport fishermen or recreational boaters at river access sites may be more effective. In addition, communication with relevant state and federal agencies should be undertaken to ensure that weed control and vegetation removal exercises are undertaken prior to the nesting season.

\section{Oil and gas activities}

Oil and gas operations pose a potential threat to piping plover habitats through disturbance and point source pollution. Most piping plover nesting habitat in northeast Montana is located within close proximity to such activities and efforts should be made to site new developments outside the immediate vicinity of essential wetland habitat. Moreover, produced water management, should be undertaken in such a way as to avoid contamination of both surface and groundwater.

\section{Contaminants}

Unhatched eggs need to collected and tested for contaminants. This is particularly important at sites within the Milk River Basin: the USGS has identified this basin as a region susceptible to irrigationinduced selenium contamination (Seiler et al 1999).

\section{Forage availability}

Preliminary data linking variables such as river hydrology, prey availability and plover reproduction suggest that alteration of the historic flow regimes along mainstem rivers may significantly impact plover reproductive success (C. Kruse, pers. comm., D. Le Fer, pers. comm.). The USFWS (2003) also recognizes that unsuitable water temperatures, below hypolimnetic dams, may negatively impact food supplies for piping plovers. Since the thermal impacts of cold hypolimnetic releases from Fort Peck Dam remain evident $280 \mathrm{~km}$ (174 rm) downstream from Fort Peck, investigations aimed at determining the impact of river hydrology, prey abundance and plover productivity below Fort Peck are warranted. Potential prey abundance needs to be documented at breeding sites and compared to sites further downstream. If invertebrate abundance is being impacted, water flow regimes along affected stretches of the Missouri River need to be managed to enhance forage availability.

\section{Updating the Piping Plover Recovery Plan}

Finally, the Northern Great Plains piping plover recovery plan, produced in 1988, is in need of revision. When undertaken, it is strongly recommended that state agencies currently involved in piping plover conservation be active participants in the decision making process. A working group including representatives from, but not limited to, the USFWS, USACE, USGS, state wildlife agencies and universities would provide a more inclusive forum for discussing and evaluating piping plover management and requirements at a variety of scales. Such involvement would likely strengthen the plan, and provide a working document specific to local and regional programs that is incorporated into a larger-scale national recovery effort. 


\section{Site Specific Recommendations within Montana}

Factors affecting piping plover habitat suitability, reproductive success and productivity vary considerably between areas, and recommendations for each are discussed in more detail below.

\section{Medicine Lake National Wildife Refuge}

Nesting beaches on Medicine Lake and other refuge impoundments are generally only exposed and available to nesting plovers during periods of severe drought, such as occurred in the early 1990s. Between 28 and 34 pairs nested on the refuge between 1990 and 1993, the last sustained drought period. Conversely, no plovers have nested on the refuge during nine of the last 10 years.

During those years when nesting plovers are present, to the extent possible, water levels should be managed to maintain wide beaches and avoid flooding nests. Supplemental protection from predators including the use of nest cages and/or electric fences should be incorporated to maximize fledgling production. Grasslands adjoining nesting beaches should also be managed using periodic grazing and prescribed burning. Cattle and other livestock should be excluded from occupied nesting beaches until after July $15^{\text {th }}$ and burns should not be conducted adjacent to nesting plovers until after plover chicks have fledged.

\section{Northeastern Montana Wetland Management District}

The Northeast Montana WMD consistently supports the highest number of breeding plovers within the state and assessing the potential for population increase should be a priority. Although this region is already tackling piping plover recovery at a broad landscape scale, habitat assessment, using remote sensing, coupled with ground truth data, is needed to develop predictive models that will aid in identification of potential nesting habitat as well as alteration in beach quality at known sites. With such information Montana will be better able to determine the actions necessary to maintain active sites, if opportunities for population increase exist, and perhaps more importantly, conduct cost-benefit analyses associated with any proposed action.

Approximately $29 \%$ (2,254.5 ha) of the critical habitat in Sheridan County is under private ownership. More importantly, in any given year about $75 \%$ of all known breeding pairs in the county occur on private lands (M. Rabenberg, pers. comm.). Consequently, private landowners must, and should, be viewed as essential partners to achieving piping plover management goals. Site specific management plans for agricultural upland areas adjacent to nesting beaches need to focus on improving nesting habitat quality through close communication with local landowners. Moreover, soliciting input from local landowners and integrating a "bottom-up" approach to habitat conservation may prove invaluable.

In Sheridan County, USFWS biologists, together with USDA NRCS staff, have already established cooperative agreements with some local landowners and assisted them, by providing technical advice and financial assistance aimed at improving piping plover habitat. More recently, the NRCS has established a special initiative for piping plover recovery through the EQIP and this provides additional means of promoting cooperation between federal agencies and private landowners. Funding is available to assist landowners interested in implementing conservation measures that improve habitat. 
Projects include:

- $\quad$ Prescribed grazing that emphasizes piping plover habitat requirements

- Wetland restoration

- $\quad$ Range seeding of native species

- $\quad$ Pasture and hayland seeding

- Water facilities for livestock, including pipelines, pumps, and wells (off-site)

Two new plover EQIP projects were initiated in 2006. These included implementing management measures on a total of 2,440 acres of lands on Flathead Farms and Solberg Livestock. Projects include: developing grazing rotation systems, removal of cattle from plover habitat and maintaining areas in grassland.

Predator exclusion has dramatically increased reproductive success within the region. Thus, increasing plover productivity through predator management should continue to be given high priority. Identifying predator communities present at specific wetland sites would be useful: such knowledge would allow managers to implement appropriate predator control measures. Likewise, studies aimed at evaluating the effectiveness of various predator control measures should be conducted. Such knowledge will likely prove more cost effective and beneficial to long term conservation objectives. Site specific recommendations are presented below.

$\underline{\text { Salt Lake }}$

Salt Lake is a large wetland characterized by good water quality but limited nesting substrate. Enhancing nesting substrate would likely increase use by breeding plovers, and efforts to haul gravel to this site were completed during winter 2005-2006. As adjacent land use is dominated by agricultural croplands, establishing cooperative agreements with local landowners to reduce erosion and sedimentation should continue to be a high priority. Furthermore, nesting and forage site quality would likely be enhanced if cropland bordering the wetland, or within the watershed basin, were seeded with grass. In addition, development of livestock off-site water sources away from plover nesting sites is warranted.

\section{Lake SE of Salt Lake}

This lake is situated within close proximity to Salt Lake and shares the same management concerns.

\section{Galloway Lake}

Galloway Lake is a seasonal wetland that is susceptible to frequent desiccation. It does, however, provide nesting habitat for plovers and is regularly utilized. Preservation of native prairie surrounding the wetland is a primary concern. Additionally, efforts should be undertaken to restore a nearby drained wetland as this may increase available nesting and foraging habitat.

\section{Lake $\mathrm{N}$ of Espen}

Site specific factors to consider include establishing cooperative agreements aimed at preserving native prairie, restoring a drained wetland up slope from the lake, monitoring impacts of oil and gas development and reducing predator habitat. 


\section{Dog Leg WPA}

Dog Leg WPA is a deep, fresh water lake that only provides suitable breeding habitat in periods of relative drought. Although it is not a high priority for piping plover wetland management, restoration of grassland habitat around the border, to a distance of approximately 80 meters, would improve nesting habitat suitability, particularly in years when other sites are not available.

\section{Anderson Lake}

Since permission to survey Anderson Lake has been hard to gain, it is difficult to ascertain how many piping plovers utilize this site. Only about $10 \%$ of the basin which is bordered by state land is currently surveyed. Priority should, therefore, be given to gaining the landowner's permission to survey the site. Protection of native prairie and returning marginal croplands to grassland on the east and south sides would increase the suitability of Anderson Lake for breeding birds.

\section{Thronveit Lake}

This lake is being actively managed for piping plovers. The majority of suitable plover nesting habitat is located on the east end of Thronveit Lake. The land owner, working with NRCS staff and federal and state biologists, entered into a cooperative land use agreement that resulted in development of a rest rotation grazing system. As a result, 266 acres of old Conservation Reserve Program (CRP) land that had been seeded was maintained and incorporated into a current grazing system. In addition, a wetland in the drainage basin above Thronveit Lake has been restored.

\section{Flat Lake}

Flat Lake has been described as the best piping plover wetland in the state and many plovers utilize this wetland during the breeding season. Primary objectives for this site include the preservation of adjacent native prairie and maintenance of CRP land as grasslands. Incorporating old CRP land into grazing systems and establishing cooperative agreements provide a means of achieving objectives.

\section{Lake $\mathrm{N}$ of Stateline}

This lake, situated to the east of Flat Lake, shares similar management concerns.

\section{North Lake (MT) and Round/Westby Lake (MT \& ND)}

Plovers do not utilize the wetlands of North Lake extensively: beach substrates are composed primarily of cobble, while waters are typically less alkaline, resulting in more emergent vegetation. There is also an active gull colony on Westby Lake. Despite such attributes, enhancement of nesting substrate in suitable areas, preservation of native adjacent prairies and active predator management would improve suitability to breeding birds.

\section{Upper Goose Lake Complex (Includes Upper Goose Lake, Smith, Murphy and Rabenberg Wetlands)} Maintaining good working relationships with the local landowners is necessary at these sites. Predator management is probably the most critical issue limiting plover productivity in this wetland complex and aggressive predator management could improve the suitability of these sites to breeding birds. In addition, preservation of native prairie and the retention of grasslands established through the CRP 
should be pursued. Methods to prevent saltwater contamination from nearby oil and gas development should be investigated.

\section{West Goose Lake}

West Goose Lake shares many of the management concerns as the Upper Goose Lake Complex. Most notably, the impact of saltwater contamination from nearby oil and gas development and protection of native prairie warrant attention. Moreover, permission to access the south portion of the lake has recently been denied. This lake is currently being targeted with the NRSC special EQIP program: goals include developing alternative livestock watering sources to protect nearby springs and limiting livestock access to West Goose Lake in order to preserve important foraging sites. In addition, removal of predator habitat such as junk piles and tree rows needs to be considered.

\section{Goose Lake WPA}

A small proportion of the Northeast Montana WMD piping plover population uses this wetland, primarily during drought periods. Goose Lake WPA has an active gull nesting colony that would need to be managed to increase use by plovers. Other factors to consider include the impact of contamination from a nearby saltwater injection site and vegetation encroachment along the shoreline. In order to enhance plover nesting sites, prescribed burning and livestock grazing outside the nesting season, should be evaluated as a means of reducing vegetation.

\section{Big Slough WPA}

This wetland is used by breeding birds but is less alkali than most other occupied lakes. As a result, vegetation is encroaching on the shoreline. Prescribed burning and grazing could be used to reduce vegetation especially in nesting and foraging areas. Efforts should also be directed at preserving CRP grassland surrounding this wetland. Moreover, the effects of nearby ground water withdrawal, for irrigation use, on wetland function should be closely monitored.

\section{Clear Lake}

Scant information is available for this wetland. While breeding birds have been known to use Clear Lake in the past, it is typically less alkaline than other occupied wetland sites. Despite low alkalinity, it does contain suitable nesting habitat on the south end. As the impact of vegetation encroachment is a concern, prescribed burning and mechanical/chemical control should be evaluated as a means of habitat enhancement.

\section{Parry Lake}

Most of Parry Lake is actively managed as a WPA. Vegetation surrounding the wetland is managed through grazing and prescribed burns and predator habitat (Russian olive trees and an old farmstead) has been removed. In addition, a cooperative agreement resulted in development of a grazing system that preserved some of the surrounding grasslands. Preservation of native prairie remains a high priority.

\section{Lake SE of Parry}

This lake is situated within close proximity to Parry Lake and shares the same management concerns. 


\section{Erickson Lake}

Erickson Lake is actively managed as part of the Erickson WPA. Management concerns include removal of predator habitat, vegetation management to reduce encroachment, and possible beach enhancement. Prescribed burning and livestock grazing outside the nesting season is used as a means of habitat enhancement. In addition, an old farmstead and several junk piles where removed.

\section{Bowdoin National Wildlife Refuge, Nelson Reservoir and Hewitt Lake National Wildlife Refuge}

Both Bowdoin NWR and Nelson Reservoir have provided nesting habitat for piping plovers in the past. Water level management appears to be the greatest obstacle to managing plover habitat and close coordination and communication with the BOR and Malta Irrigation District should continue to be a high priority in future years.

Since few plover pairs establish nests relative to the number of breeding birds that are censused, it is possible that suitable habitat is lacking. Consideration should be given to conducting a larger scale habitat assessment: this would provide a means of identifying potential nesting sites and factors limiting beach quality at known sites.

Nest protection has been an effective predator management tool in many areas, and nesting cages are available to reduce predator impacts. The use of nest cages in this region should, however, be based on the amount of secure nesting habitat available, the threat of potential predators using the area and the proximity of areas to high recreational use. Consultation with regional biologists suggests that nest cages, coupled with restrictive signage, may increase human related disturbance, negating the positive effects of predator exclosures. Nest cages may enhance productivity on isolated islands subject to little human disturbance, but may not be appropriate along shorelines frequented by recreational users.

Efforts to gather productivity data should be made in years when plovers are known to be nesting. This might include data similar to that gathered by the USACE. Identification of nests, number of eggs, fate of clutch, and number fledged would all provide valuable productivity data for the wetland complex and increase understanding of factors limiting reproduction.

This region is susceptible to irrigation-induced selenium contamination (Seiler et al 1999) and as a consequence the impact of contaminants on plover eggs and productivity needs further study. It is recommended that unhatched eggs be collected and tested.

\section{Nelson Reservoir}

Nelson Reservoir is an irrigation reservoir managed by the BOR (USFWS 2002). In the past, rising water levels have necessitated nest relocation, however, it is currently operated under a Biological Opinion that directs the BOR to fill the reservoir prior to plover arrival in the spring thus reducing nest prevention and/or flooding of nest sites. It is recommended that water management continue to be the primary method for protecting piping plover nests on Nelson Reservoir, however, if it proves impossible to physically manage water, nests should be relocated to prevent inundation. 
Although predator monitoring around known nest sites should be conducted, predator control, using nest exclosures, must be carefully considered: along beach shorelines, the use of signage and nest structures has the potential to draw attention and lead to further disturbance by recreational users (K. Tribby, pers. comm.). During low water years, habitat enhancement through mechanical removal of encroaching vegetation should be encouraged to enhance and preserve nesting habitat. Manipulation of beaches, through substrate enhancement (using clean gravel), to promote nesting during high water years should also be continued.

Close coordination between BOR, the Bureau of Land Management, and Bowdoin NWR has proven that natural gas well drilling activity can be accommodated near piping plover nesting beaches on Nelson Reservoir. Continued coordination and monitoring would allow drilling activity in years when plovers are not present while protecting beaches in years with nesting activity.

\section{Bowdoin NWR}

Bowdoin is an off-stream facility that receives water from the Milk River (USFWS 2002). Water management at Bowdoin NWR and Nelson Reservoir should be coordinated wherever possible during years with high water levels to prevent rapid elevations in water level during the plover nesting season.

Within the refuge, breeding birds traditionally utilize Piping Plover Pond (formally Dry Lake) however water level management has proved problematic. During many years, water levels at this wetland are low and if additional water is available from the BOR or Malta Irrigation District, it has to be run through a circuitous network of canals that fill up other wetland sites first. Moreover, as water level management for plovers needs to occur during early spring or late fall, appropriate timing is critical. Improved communication with the BOR and Irrigation District is needed and it is recommended that discussions regarding water level and timing requirements be entered into. An option worth exploring is that of mitigation through water donation by the BOR. Managing nest sites at Nelson Reservoir have proved problematic in the past due to elevated water levels while Bowdoin NWR is frequently faced with water shortages at critical nest sites. Plover productivity could potentially be improved at a regional scale by providing Bowdoin NWR with water on an annual basis as compensation for sites lost at Nelson Reservoir.

Substrate enhancement has been undertaken in prior years at Piping Plover Pond and efforts are under way to haul gravel to this site in winter 2005. As the substrate around the lake is relatively soft (K. Tribby, pers. comm.), this should be approached with caution, and undertaken only if the ground is suitably frozen. More importantly, efforts should be made to ensure that washed gravel is utilized to reduce the possibility of degrading habitat through the unintentional introduction of soil and seeds. In addition, predator monitoring and management should be considered when appropriate within the NWR.

\section{Hewitt Lake NWR}

Hewitt Lake is a basin lake that receives water from seepage flow, surface precipitation and spring runoff. Piping plover use has not been documented because of dry conditions in most years (Montana Piping Plover Recovery Committee 1997). In years when water is present, the shoreline provides semi- 
alkaline gravel beach habitat, but vegetation encroachment has reduced any potentially useful nesting habitat. Initiating vegetation removal, and substrate enhancement, to create potential nesting habitat is a possibility, as is working with the BOR to facilitate water donation and delivery to this site.

\section{Missouri River and Fort Peck Reservoir}

Water level management, coupled with the ensuing variation in suitable habitat availability, is the key determinant of piping plover presence and productivity, and the USACE is strongly urged to restore the river to a more natural flow regime. Criteria for improved spring flows and warm water releases from Fort Peck have been jointly developed by numerous federal and state agencies, including the USACE, and are laid out in the USFWS Biological Opinion (2003). Regional drought conditions delayed implementation, however, it is hoped that the USACE will carry out these recommendations as soon as reservoir elevation and runoff criteria can be met.

Artificial flooding via high dam releases from Fort Peck Dam will likely scour vegetation from existing sandbars, but may not bring suspended and bed-load sediment from upstream. In order to assess habitat availability under different operational scenarios, monitoring reproductive success and mapping essential piping plover breeding habitat should continue. Such evaluations will hopefully provide estimates of current levels of productivity as well as the potential for population change under differing water management regimes.

\section{Fort Peck Reservoir}

Although Fort Peck Reservoir represents the western edge of piping plover habitat and traditionally contains few piping plovers relative to other areas within the Missouri River drainage system (USFWS 2003), birds do frequent the eastern Big Dry Creek Arm. The amount of available habitat varies, however, depending on water level management: in years when adequate nesting and foraging habitat is available, proportionately more birds utilize shoreline beaches. Estimating the amount of potential piping plover habitat available as well as specific enhancement actions would provide valuable information to managers. Habitat improvement (i.e. vegetation removal) should be considered as a management goal to increase available habitat and productivity.

As rapidly rising water levels at Fort Peck have played a role in limiting reproductive success in the past, water level manipulation should be considered to prevent future nest inundations. Discharge of water to mimic a more natural high spring flow would not only increase habitat availability downstream, by scouring vegetation from sandbars, but also lower water levels at the reservoir prior to the nesting season. Such a strategy should be considered as it would expose nesting habitat along the reservoir shoreline and reduce the threat of inundation due to storm spikes. In addition, considerably less effort would be expended in nest relocation. Regular meetings between plover monitoring crews and water control personnel may also help reduce nest flooding and/or provide increased windows of time to initiate management actions, should it become necessary. In years when nests are lost, due to USACE water management operations, off-site mitigation to support habitat restoration projects and/or the purchase of easements at alkaline wetland sites, may be worth exploring. 
Although documented nest loss due to human disturbance does not appear to be significant at this time, human disturbance has reportedly caused problems in the past. Monitoring should be undertaken and action taken when necessary to reduce impacts. Interpretive signage and education of the general public may prove more effective than restrictive signage and enforcement. Regional biologists and law enforcement officials, familiar with plover biology, could determine the appropriate action should disturbance become a problem.

\section{Missouri River, below Fort Peck Dam}

Managing flooding along the Fort Peck river reach of the Missouri to mimic a more natural hydrograph should be the primary management objective. Incorporating a naturalized flow regime would clearly help restore essential habitat as well as the dynamic hydrologic and ecological processes that maintain them. Short term habitat enhancement, through vegetation removal, should also be considered at sites known to support plovers. In addition, efforts should continue to reduce untimely discharges of accumulated spring water from Fort Peck Reservoir during critical nesting periods.

The effects of cold hypolimnetic releases on forage availability for piping plovers have yet to be determined for the Missouri River. It is recommended that a study be undertaken to evaluate piping plover productivity and chick growth rates relative to invertebrate abundance on the river reach below Fort Peck Reservoir. If results indicate that productivity is being negatively impacted, warm water releases will need to be considered. As sustained drought periods, such as characterized the region in 2000 through 2004, result in lower water levels at Fort Peck Reservoir, spillway releases are not always an option. Likewise, warmer waters downstream of the dam would ideally be required throughout the summer months when water flows need to be reduced. Researching the feasibility of drawing water for the powerhouse from the upper layers of the lake should be investigated.

Predation rates do not appear to be high along this river reach, but monitoring should continue. As predator pressure will likely be site specific, management techniques should be determined based on the specific situation. Predator removal or elimination may be useful as a short term measure whereas exclosures could be employed if predation persists.

Human and livestock disturbance does not appear to be negatively impacting reproductive success along the Missouri River in Montana at this time but human use monitoring should be conducted. If disturbance patterns change, interpretive signage and education of the general public may prove more effective than restrictive signage and enforcement. Regional biologists and law enforcement officials, familiar with plover biology, could determine site appropriate action.

\section{Future Research}

1. Biological studies aimed at determining invertebrate abundance, and piping plover chick growth rates along the Missouri River in Montana is warranted.

2. Population viability models for piping plovers are particularly sensitive to adult survival estimates. Additional banding studies would increase our knowledge of adult mortality rates and improve predictive models. 
3. Although fledgling success is widely used as an index of reproductive success in avian studies, survival of the young after fledging is rarely estimated (Keedwell 2003). As mortality may be significant during this period, telemetry and/or banding studies aimed at determining mortality rates in the postfledging period would provide more precise information on productivity of plovers in the Northern Great Plains. This would also provide more accurate data on juvenile survival that could be used for population modeling.

4. Populations of several important avian predators have increased in Montana in recent years (Sauer et al 2001), and research aimed at determining both the abundance and impacts of predators such as large gulls (Larus spp.) and American crows (Corvus brachyrhychos) may be warranted at some sites.

5. Landscape level habitat evaluation within the state would provide useful data for assessing the potential for population increase at both occupied and unoccupied nest sites. With this information, Montana will be in a stronger position to evaluate whether current management options are adequate to meet long term objectives. Moreover, current management practices should be examined to determine whether opportunities for population increase are being missed. 


\section{REFERENCES}

Adam, C. I. G. 1984. The piping plover, Charadrius melodus, at Lake Athabasca, Saskatchewan: a significant northward range extension. Canadian Field-Naturalist 98: 59-60.

Alberta Piping Plover Recovery Team. 2005. Implementation of the Alberta piping plover recovery plan 202-2004. Final Program Report. Alberta Sustainable Resource Development, Fish and Wildlife Division, Alberta Species at Risk Report No. 99, Edmonton, Alberta. 19 pp.

AOU. 1886. Check-list of North American birds. 1 ${ }^{\text {st }}$ Edition. American Ornithological Union.

AOU. 1895. Check-list of North American birds. $2^{\text {nd }}$ Edition. American Ornithological Union.

AOU. 1945. Twentieth supplement to the check-list of North American birds. Auk 62: 436-449.

AOU. 1957. Check-list of North American Birds, $5^{\text {th }}$ Edition. American Ornithological Union, Washington, D.C.

AOU. 1998. Check-list of North American Birds. $7^{\text {th }}$ Edition. American Ornithological Union, Washington, D.C.

Armbruster, M. J. 1986. A review of habitat criteria for least terns and piping plovers using the Platte River. National Ecology Research Center, U.S. Fish and Wildlife Service, Fort Collins, Colorado. Unpublished Report.

Aron, C. 2005. South Dakota interior least tern (Sterna antillarum athalassos) and piping plover (Charadrius melodus) management plan. South Dakota Department of Game, Fish and Parks, Pierre, Wildlife Division Report No. 2005-02. 59 pp.

Beckerman, S. J. 1988. Time-budget of piping plovers in central North Dakota. Honors Thesis, University of Missouri, Columbia, MO.

Bent, A. 1929. Life Histories of North American Shore Birds. Pt 2. U.S. Natural Museum Bulletin 146: 236246.

Bergeron, D., Jones, C., Genter, D. L. and Sullivan, D. 1992. P.D. Skaar's Montana bird distribution, Fourth Edition. Montana Natural Heritage Prog. Spec. Publ. No. 2. 116p.

Brown, S. 1986. Managing different populations of a species: the case of the piping plover. University of Michigan. Endangered Species Technical Bulletin Report. 2pp.

Burger, J. 1994. The effect of human disturbance on foraging behavior and habitat use in piping plover (Charadrius melodus). Estuaries 17: 695-701.

Burger, J., Parsons, K., Wartenberg, D., Safina, C., O'Connor, J. and Gochjield, M. 1994. Biomonitoring using least terns and black skimmers in the northeastern United States. Journal of Coastal Research 10: 39-47. 
Cairns, W. E. 1977. Breeding biology and behaviour of the piping plover Charadrius melodus in southern Nova Scotia. M.S. Thesis. Dalhousie University, Halifax, Nova Scotia. 115 pp.

Cairns, W. E. 1982. Biology and breeding behavior of breeding piping plovers. Wilson Bulletin 94: 531-545.

Carlson, C. and Skaar, P. D. 1976. Piping plover in Montana. Western Birds 7:69-70.

Clapp, R. B., Klimkiewicz, M. K. and Kennard, J. H. 1982. Longevity records of North American birds: Gaviidae through Alcidae. Journal of Field Ornithology 53: 81-124, 125-208.

Corn, J. G. and Armbruster, M. J. 1993. Prey availability for foraging piping plovers along the Platte River, Nebraska. In Higgins, K. F. and Brashiers, M. R., (eds.) Proceedings Missouri River and its tributaries: piping plover and least tern symposium, South Dakota State University, Brookings, SD.

Cross, R. R. 1991. Monitoring, management, and research of the piping plover at Chincoteague National Wildlife Refuge. Unpublished report. Virginia Department of Game and Inland Fisheries, Richmond, Virginia. 76 pp.

Dahl, T. E. 1992. Wetlands losses in the United States: 1780 's to 1980 's. Report to Congress. U. S. Fish and Wildlife Service, Washington, D.C.

Drake, K. R., Thompson, J. E., Drake, K. 1. and Zonick, C. 2001. Movements, habitat use and survival if non-breeding piping plovers. Condor 103: 259-267.

Elias, S. P, Fraser, J. D. and Buckley, P. A. 2000. Piping plover brood foraging ecology on New York barrier islands. Journal of Wildlife Management 64: 346-354.

EPA. 2000. Profile of the oil and gas extraction industry. EPA/310-R-99-006. Environmental Protection Agency Office of Compliance Sector Notebook Project, Office of Compliance, Washington D.C. $165 \mathrm{pp}$.

Euliss, N. H. Jr. and Mushet, D. M. 1996. Water-level fluctuation in wetlands as a function of landscape condition in the prairie pothole region. Wetlands 16:587-593.

Euliss, N. H., Jr. and Mushet, D. M. 1999. Influence of agriculture on aquatic invertebrate communities of temporary wetlands in the prairie pothole region of North Dakota, USA. Wetlands 19: 578-583.

Euliss, N. H., Jr., Mushet, D. M. and Wrubleski, D. A. 1999. Wetlands of the Prairie Pothole region: invertebrate species composition, ecology, and management. In Batzer, D. P, Rader, R. B. and Wissinger, S. A, (eds.). Invertebrates in Freshwater Wetlands of North America: Ecology and Management. John Wiley \& Sons, New York.

Espie, R. H. M., Brigham, R. M. and James, P. C. 1996. Habitat selection and clutch fate of piping plover (Charadrius melodus) breeding at Lake Diefenbaker, Saskatchewan. Canadian Journal of Zoology 74: 1069-1075. 
Espie, R. H. M., James, P. C. and Brigham, R. M. 1998. The effects of flooding on piping plover reproductive success at Lake Diefenbaker, Saskatchewan, Canada. Biological Conservation 86: 215222.

Faanes, C. A. 1983. Aspects of the nesting ecology of least terns and piping plovers in central Nebraska. Prairie Naturalist 15: 145-154.

Fannin, T. E. and Esmoil, B. J. 1993. Metal and organic residues in addled eggs of least terns and piping plovers in the Platte Valley of Nebraska. In Higgins, K.F. and M.R. Brashier (eds.) Proceedings, The Missouri River and its tributaries piping plover and least tern symposium/workshop. South Dakota State University, Brookings, SD.

Ferland, C. L. and Haig, S. M. 2002. 2001 International piping plover census. U.S. Geological Survey, Forest and Ecosystem Center, Corvallis, OR. 293 pp.

Galat, D. L. and Lipkin, R. 2000. Restoring ecological integrity of great rivers: historical hydrographs aid in defining reference conditions of the Missouri River. Hydrobiologia 422/423: 29-48.

Gleason, R. A. 1996. Influence of agricultural practices on sedimentation rates, aquatic invertebrates, and bird-use in prairie wetlands. M.S. Thesis. Humboldt State University, Arcata, CA.

Gleason, R. A. and Euliss, N. H. Jr. 1996. Sedimentation of prairie pothole wetlands: the need for integrated research by agricultural and wildlife interests. Proceedings of the 1996 wetlands seminar, Water for agriculture and wildlife and the environment-win-win opportunities. U.S. Committee on Irrigation and Drainage, Denver, CO.

Gleason, R. A. and Euliss, N. H. Jr. 1998. Sedimentation of prairie wetlands. Great Plains Research 8:97-112.

Gleason, R. A. Euliss, N. H. Jr., Hubbard, D. E. and Duffy, W. G. 2003. Effects of sediment load on emergence of aquatic invertebrates and plants from wetland soil egg and seed banks. Wetlands 23: 26-24.

Goossen, J. P., Amirault, D. L., Arndt, J., Bjorge, R., Boates, S., Brazil, J., Brechtel, S., Chiasson, R., Corbett, N. G., Curley, R., Elderkin, M., Flemming, S. P., Harris, W., Heyens, L., Hjertaas, D., Huot, M., Johnson, B., Jones, R., Koonz, W., Laporte, P., McAskill, D., Morrison, R. I. G., Richard, S., Shaffer, F., Stewart, C., Swanson, L. and Wilte, E. 2002. National recovery plan for the piping plover (Charidrius melodus). National Recovery Plan No. 22. Recovery for Nationally Endangered Wildlife, Ottawa, Ontario, Canada.

Graul, W. D. 1973. Possible functions in head and breast markings in Charadrinii. Wilson Bulletin 85: 6070.

Grue, C. E., Tome, M. W., Messmer, T. A., Henry, D. B., Swanson, G. A. and DeWeese, L. R. 1989. Agricultural chemicals and prairie pothole wetlands: meeting the needs of the resource and the farmer U.S. perspective. Transactions of the North American Wildlife and Natural Resources Conference 54:43-58. 
Haig, S. M. 1992. Piping Plover. In: Poole, A., Stettenheim, P. and Gills, F. (eds) The Birds of North America, No. 2. American Ornithological Union, Washington, D. C. USA, and the Academy of Natural Sciences, Philadelphia, PA, USA.

Haig, S. M. 1998. Molecular Contributions to Conservation. Ecology 79: 413-425.

Haig, S. M. and Elliot-Smith, E. 2004. Piping plover. In: Poole, A. (ed) The Birds of North America Online. Ithaca: Cornell Laboratory of Ornithology; retrieved from the Birds of North America Online database: http://bna.birds.cornell.edu/BNA/account/Piping Plover/.

Haig, S. M. and Oring, L. W. 1985. Distribution and status of the piping plover throughout the annual cycle. Journal of Field Ornithology 56: 334-345.

Haig, S. M. and Oring L. W. 1987. The piping plover. In: Audubon Wildlife Report 1987. National Audubon Society, Academic Press, New York. p. 509-518.

Haig, S. M. and Oring, L. W. 1988a. Genetic differentiation of piping plovers across North America. Auk 105: 260-267.

Haig, S. M. and Oring, L. W. 1988b. Distribution and dispersal in the piping plover. Auk 105: 630-638.

Haig, S. M. and Oring, L. W. 1988c. Mate, site and territory fidelity in piping plovers. Auk 105: 268-277.

Haig, S. M. and Plissner, J. H. 1993. Distribution and abundance of piping plovers: results and implications of the 1991 international census. Condor 95: 145-156.

Haig, S. M., Ferland, C. L., Cuthbert, F. J., Dingledine, J., Goossen, J. P., Hecht, A and McPhilllips, N. 2005. A complete species census and evidence for regional declines in piping plovers. Journal of Wildlife Management 69: 160-173.

Hesse, L. W. and Mestl, G. E. 1993. An alternative hydrological cycle for the Missouri River based on precontrol conditions. North American Journal of Fisheries Management 13: 360-366.

Hoopes, E.M., Griffin, C. R. and Melvin. S. M. 1989. Atlantic Coast Piping Plover winter distribution Survey. Unpublished report to the U.S. Fish and Wildlife Service, Newton Corner, Massachusetts. $6 \mathrm{pp}$.

Hothem, R. L. and Powell A.N. 2000. Contaminants in eggs of western snowy plovers and California least terns: is there a link to population decline? Bulletin of Environmental Contamination and Toxicology 65: 42-50.

IUCN. 2005. The IUCN Red List of threatened species. Retrieved from the IUCN Red List online database: http://www.iucn.org/themes/ssc/red-lists.htm.

Ivan, J. S. and Murphy, R. K. 2005. What preys on piping plover eggs and chicks? Wildlife Society Bulletin 33: 113-119. 
Johnson, W. C., Burgess, R.L. and Keammerrer, W.R. 1976. Forest overstory vegetation and environment on the Missouri River floodplains in North Dakota. Ecological Monographs 46: 59-64.

Johnson, W. C., Boettcher, S. E., Poiani, K. A. and Guntenspergen, G. 2004. Influence of weather extremes on the water levels of glaciated prairie wetlands. Wetlands 24: 385-398.

Kantrud, H. A. and Newton, W. E. 1996. A test of vegetation-related indicators of wetland quality in the Prairie Pothole Region. Aquatic Ecosystem Health Management 5: 177-191.

Keedwell, R. J. 2003. Does fledging equal success? Post-fledging mortality in the black-fronted tern. Journal of Field Ornithology 74: 217-221.

Keedwell, R. J. 2004. Use of population viability analysis in conservation management in New Zealand. Science for Conservation 243. 60 pp.

Kirsch, E. M. and Sidle, J. G. 1999. Status of the interior population of least terns. Journal of Wildlife Management 63: 470-483.

Knetter, J. M., Lutz, R. S., Cary, J. R. and Murphy, R. K. 2002. A multi-scale investigation of piping plover productivity on Great Plains alkali lakes, 1994-2000. Wildlife Society Bulletin 30: 683-694.

Kruse, C. D., Higgins, K. F. and Vander Lee, B. A. 2001. Influence of predation on piping plover, Charadrius melodus, and least tern, Sterna antillarum, productivity along the Missouri River in South Dakota. Canadian Field Naturalist 115: 480-486.

Larson, M. A., Ryan, M. R. and Root, B. G. 2000. Piping plover survival in the Great Plains: an updated analysis. Journal of Field Ornithology 71: 721-729.

Larson, M. A., Ryan, M. R. and Murphy, R. K. 2002. Population viability of piping plovers: effects of predator exclusion. Journal of Wildife Management 66: 361-371.

Larson, M. A. Ryan, M. R. and Murphy, R. K. 2003. Assessing recovery feasibility for piping plovers using optimization and simulation. Wildlife Society Bulletin 31: 1105-1116.

Lebreton, J. D. Burnham, K. P., Clobery, J. and Anderson, D. R. 1992. Modeling survival and testing biological hypotheses using marked animals: a unified approach with case studies. Ecological Monographs 62: 67-118.

Lenard, S., Calson, J., Ellis, J., Jones, C. and Tilly, C. 2003. P.D. Skaar's Montana Bird Distribution, $6^{\text {th }}$ Edition. Montana Audubon, Helena, MT.

Licht, D. S. 2001. Relationship of hydrological conditions and populations of breeding piping plovers. Prairie Naturalist. 33: 209-219.

Loegering, J. P. and Fraser, J. D. 1995. Factors affecting piping plover chick survival in different brood rearing habitats. Journal of Wildlife Management 59: 646-655. 
MacIvor, L. H. 1990. Population dynamics, breeding ecology and management of piping plovers on outer Cape Cod, Massachusetts. M.S. Thesis. University of Massachusetts, Amherst, Massachusetts, 100 pp.

MacIvor, L. H., Melvin, S. M. and Griffin, C. R. 1990. Effects of research activity on piping plover nest predation. Journal of Wildlife Management 54: 443-447.

Martin, D. B. and Hartman, W. A. 1986. The effect of cultivation on sediment and deposition in prairie pothole wetlands. Water, Air, and Soil Pollution 34: 45-53.

Mayer, P. M. 1991. Conservation biology of piping plovers in the Northern Great Plains. M.S. Thesis. University of Massachusetts, MA.

Mierzykowski S.E. and Carr, K. C. 2004. Environmental contaminants in piping plover, least tern and common tern eggs from coastal Maine -2003 nesting season. U.S. Fish and Wildlife Service. Spec. Proj. Rep. FY04-MEFO-1-EC. Old Town, ME.

Mitchell, W. A., Guilforyle, M. P. and Wolters, M. S. 2000. Riparian shorebirds potentially impacted by USACE reservoir operations. EMRRP Technical Notes Collection (ERDC TN-EMRRP-SI-17), U. S. Army Corp of Engineer Research and Development Center, Vicksburg, MS. www.wes.army.mil/el/emrrp.

Montana Bird Distribution Database. 2005. Retrieved from the Montana Bird Distribution Online Database Online, Helena, Montana. http://nhp.nris.state.mt.us/mbd/

MFWP, 2005. 2004 Annual Fish, Wildlife and Parks Drought Summary. Prepared for: Governor's Drought Advisory Committee. Montana Fish, Wildlife and Parks. Unpublished Report. 20 pp.

Montana Piping Plover Recovery Committee. 1997. 1995 Surveys for piping plovers (Charadrius melodius) and least terns (Sterna antillarum) in Montana. Unpublished Report. 114 pp.

Moser, R. A. 1942. Should the belted piping plover be recognized as a valid race? Nebraska Bird Review 10: 31-37.

Murphy, R. K., Rabenberg, M. J., Sondereal, M. L., Casler, B. R. and Guenther, D. A. 2000. Reproductive success of piping plovers on alkali lakes in North Dakota and Montana. Prairie Naturalist 32: 233241.

Murphy, R. K., Michaud, I. M. G., Prescott, D. R. C., Ivan, J. S., Anderson, B. J. and French-Pombier, M. L. 2003. Predation on adult piping plovers at predator exclosure cages. Waterbirds 26: 150-155.

Murray, B. G. Jr. 1985. Evolution of clutch size in tropical species of birds. Ornithological Monographs 36: 505-519.

National Research Council. 2001. Compensating for wetland losses under the Clean Water Act. Committee on Mitigating Wetland Losses, Board on Environmental Studies and Toxicology, Water Science and Technology Board, Division on Earth and Life Studies and National Research Council, National Academy Press, Washington D.C. 322 pp. 
National Research Council. 2002. The Missouri River Ecosystem: exploring the prospects for recovery. Committee on Missouri River Ecosystem Science, Water Science and Technology Board, Division on Earth and Life Studies, National Research Council, National Academy Press, Washington D.C. $176 \mathrm{pp}$.

National Research Council. 2004. Endangered and Threatened Species of the Platte River. Committee on Endangered and Threatened Species in the Platte River Basin, National Research Council, National Academy Press, Washington D.C. 336 pp.

Neely, R. K. and Baker, J. L. 1989. Nitrogen and phosphorus dynamics and the fate of agricultural runoff In van der Valk, A. (ed), Northern Prairie Wetlands. Iowa State University Press, Ames, IA.

Nelson, K. 2006. Montana - Impacts of oil exploration and production to the northeast Montana Wetland Management District. Project Proposal ID: 6N51, U.S. Fish and Wildlife Service, Region 6. $33 \mathrm{pp}$.

Nicholls, J.L. 1989. Distribution and other ecological aspects of piping plovers (Charadrius melodus) wintering along the Atlantic and Gulf Coasts. M.S. Thesis. Auburn University, Auburn, Alabama. $150 \mathrm{pp}$.

Nicholls, J. L. and Baldassarre, G. A. 1990a. Winter distribution of piping plovers along the Atlantic and Gulf coasts of the United States. Wilson Bulletin 102: 400-412.

Nicholls, J. L. and Baldassarre, G. A. 1990b. Habitat associations of piping plovers wintering in the United States. Wilson Bulletin 102: 581-590.

North, M. R. 1986. Piping plover nest success on Mallard Island in North Dakota and implications for water management. Prairie Naturalist 18: 117-122.

O'Connor, R. J. 1977. Differences in growth and body composition in altricial passerines. Ibis 119: 147-166.

Ohlendorf H. M., Hothem R. L., Bunck C. M., Aldrich T. W. and Moore J. F. 1986. Relationships between selenium concentrations and avian reproduction. Trans North American Wild1ife Natural Resource Conference 51: 330-342

Oring, L., Harington, B., Brown, S. and Hickey, C. 2000. National shorebird research needs: a proposal of a national research program and example high priority research topics. Manomet Center for Conservation Sciences. http://www.manomet.org/USSCP/files.htm. Technical Report of the Research and Monitoring Work Group of the U.S. Shorebird Conservation Plan.

Phillips, R. L., Beeri, O. and Dekeyer, E. S. 2005. Remote wetland assessment for Missouri Coteau prairie glacial basins. Wetlands 25: 335-349.

Plissner, J. H. and Haig, S. M. 1997. 1996 international piping plover census. Report to U.S. Geological Survey, Biological Resources Division, Forest and Rangeland Ecosystem Science Center, Corvallis, OR, USA. 
Plissner, J. H. and Haig, S. M. 2000. Status of a broadly distributed endangered species: results and implications of the second international piping plover census. Canadian Journal of Zoology 78: 128139.

Power, G., Ryckman, F., Hendrickson, J., Lee, J., Grondahl, C., and Bruning, D. 2000. 'Cross the wide Missouri: Significant Missouri River system biological sites. North Dakota Outdoors 63(8): 6-20.

Prellwitz, D. M., Prellwitz, T. A., Stutzman, K. K. and Stutzman, J. W. 1989. Piping plovers nesting at Nelson Reservoir, Montana. Prairie Naturalist 21: 84-86.

Prescott, D. R. C. 1997. Status of the piping plover (Charadrius melodus) in Alberta. Alberta Wildlife Status Report Series No 1. Alberta Environmental Protection. Edmonton, Alberta, AB. 19 pp.

Prescott, D. R. C. 2001. The 2001 international piping plover census in Alberta. Alberta Sustainable Resource Development, Fish and Wildlife Division, Alberta Species at Risk Report No. 27, Edmonton, Alberta. 15 pp.

Prindiville, E. M. 1986. Habitat selection and productivity of the piping plover in central North Dakota. M. S. Thesis. University of Missouri, Columbia, MO.

Prindiville-Gaines, E. and Ryan, M. 1988. Piping plover habitat use and reproductive success in North Dakota. Journal of Wildlife Management 52: 266-273.

Ruelle, R. 1993. Contaminant evaluation of interior least tern and piping plover eggs from the Missouri River in South Dakota. Pages 159-171 In Higgins, K. F and Brashier, M. R., (eds). Proceedings, The Missouri River and its tributaries: piping plover and least tern symposium. South Dakota State University, Brookings, SD.

Russel, R. P. 1983. The piping plover in the Great Lakes region. American Birds 37: 951-955.

Root, B. G. and Ryan, M. R. 2004. Changes in piping plover nesting habitat availability at Great Plains alkaline wetlands, 1938-1997. Wetlands 24: 766-776.

Ryan, M. R., Root, B. G. and Mayer, P. M. 1993. Status of piping plovers in the Great Plains of North America: a demographic simulation model. Conservation Biology 7: 581-585.

Ryba, A. 2004. Conservation of piping plovers in the U.S. Alkali Core Area: 2004 field effort summary report. U.S. Fish and Wildlife Service. Unpublished report. 7 pp.

Ryba, A. 2005. Conservation of piping plovers in the U.S. Alkali Core Area: 2005 field effort summary report. U.S. Fish and Wildlife Service. Unpublished report. 7 pp.

Ryder, O. A. 1986. Species conservation and systematics: the dilemma of subspecies. Trends in Ecology and Evolution 1: 9-10.

Sargeant, A. B., Greenwood, R. J., Sovada, M. A. and Shaffer, T. L. 1993. Distribution and abundance of predators that affect duck production: prairie pothole region. U. S. Fish and Wildlife Service Resource Publication 194. Washington D. C. 
Sauer, J. R., Hines, J. E. and Fallon, J. 2001. The North American breeding bird survey, results and analysis 1966-2000. Version 2001.2. United States Geological Survey, Patuxent Wildlife Research Center, Laurel, MD.

Schulenberg, J.H., and M.B. Schulenberg. 1982. Status of the interior least tern in Kansas - 1982. Kansas Fish and Game Commission, Nongame Wildlife Project. 55 pp.

Schwalbach, M. J. 1988. Conservation of least terns and piping plovers along the Missouri River and its major western tributaries in South Dakota. M.S. Thesis, South Dakota State University, Brookings, SD.

Schwalbach, M. J., Higgins, K. F., Dinan, J. Dirks, B. J., and Kruse, C. D. 1993. Effects of water levels on interior least terns and piping plover nesting along the Missouri River in South Dakota In: Higgins, K. F. Brashier, M. R. (eds). Proceedings, the Missouri River and its tributaries: piping plover and least tern symposium, South Dakota State University, Brookings, SD, pp. 75-81.

Seiler, R. L., Skorupa, J. P. and Peltz, L. A. 1999. Areas susceptible to irrigation-induced selenium contamination of water and biota in the western United States. U.S. Geological Survey Circular 1180, Denver, CO.

Shaffer, F. and Laporte, P. 1994. Diet of piping plovers on the Magdelen Islands, Quebec. Wilson Bulletin 106: 531-536.

Shields, F. D., Jr., Simon, A. and Steffen, L. J. 2000. Reservoir effects on downstream river channel migration. Environmental Conservation 27: 54-66.

Sibley, D. A. 2003. Field Guide to Western North American Birds. Knopf Publishers, New York. 471 pp.

Sidle, J. G., and Kirsch. E. M. 1993. Least terns and piping plovers nesting at sandpits in Nebraska. Colonial Waterbirds 16: 139-148.

Sidle, J. G., Carson, D. E., Kirsch, E. M. and Dinan, J. J. 1992. Flooding: mortality and habitat renewal for least terns and piping plovers. Colonial Waterbirds 15: 132-136.

Skaar, D., D. Flath, and L. S. Thompson. 1985. Montana bird distribution. Monograph \#3, supplement vol. 44. Proceedings Montana Academy of Sciences. 71 pp.

Skagen, S. K. and Knoff, F. L. 1994. Towards conservation of mid-continental shorebird migrations. Conservation Biology 7: 533-541.

Skagen, S. K. and Thompson, G. 2005. U.S. Shorebird Conservation Plan: northern plains/ prairie potholes regional shorebird conservation plan: version $1.33 \mathrm{pp}$.

Sloan, C. E. 1972. Ground-water hydrology of prairie potholes in North Dakota. Geological Survey Professional Paper 585-C. 
Slizeski, J. J., Anderson, J. L. and Durough, W. G. 1982. Hydrologic setting, system operation, present and future stresses. Pages 15-37. In: Hesse et al., Eds. The Middle Missouri River. Norfolk, NE: Missouri River Study Group.

Smith, K. A. Murphy, R. K, Michaelson, D. L. and Viehl, W. C. 1993. Habitat and predation management for nesting piping plovers at Lostwood National Wildlife Refuge, North Dakota. Prairie Naturalist 25: 139-147.

Strauss, E. 1990. Reproductive success, life history patterns, and behavioral variation in a population of piping plovers subjected to human disturbance (1982-1989). Ph.D. Dissertation. Tufts University, Medford, Massachusetts. 143 pp.

Stucker, J. H. and Cuthbert, F. J. 2006. Distribution of non-breeding Great Lakes piping plovers along the Altantic and Gulf of Mexico coastlines: 10 years of band re-sightings. Report to U.S. Fish and Wildlife Service, East Lansing and Panama Field Offices. 20 pp.

Tate, J. 1981. Blue list for 1981. American Birds 35:3-10.

USACE. 1997. Missouri River interior least tern and piping plover status and productivity summary, including permit activity report. December 1997. U.S. Army Corp of Engineers, Omaha District. 40pp.

USDA. 2002. Assessing wetland functional condition change in agricultural landscapes. U. S. Department of Agriculture, National Resources Conservation Service. Wetlands Technical Note No.1. 34 pp.

USFWS. 1985. Endangered and threatened wildlife and plants; determination of endangered and threatened status for the piping plover: final rule. Federal Register 50: 50720-50734.

USFWS. 1988. Recovery Plan for piping plovers (Charadrius melodus) of the Great Lakes and Northern Great Plains. U. S. Fish and Wildlife Service, Twin Cities, MN.

USFWS. 1990. Biological opinion of the operations of the Missouri River Main Stem System. Letter from U. S. Fish and Wildlife Service, Denver Colorado, to U. S. Army Corp of Engineers, Omaha, Nebraska, dated November 14 1990. 72 pp.

USFWS. 1994. Draft revised recovery plan for piping plovers (Charadrius melodus) breeding on the Great Lakes and Northern Great Plains. U.S. Fish and Wildlife Service, Twin Cities, MN.

USFWS. 1996. Piping Plover (Charadrius melodus), Atlantic Coast Population, Revised Recovery Plan. U.S. Fish and Wildlife Service, Hadley, Massachusetts. 258 pp.

USFWS. 2002. Endangered and threatened wildlife and plants; designation of critical habitat for the Northern Great Plains breeding population of piping plover: final rule. Federal Register 67: 5763857717. 
USFWS. 2003. Biological opinion on the operation of the Missouri River main stem reservoir system, operation and maintenance of the Missouri River bank stabilization and navigation project and operation of the Kansas River reservoir system. U.S. Fish and Wildlife Service. 296pp + appendices.

USGS. 2003. Species found positive for West Nile Virus during surveillance efforts. U.S. Geological Survey http://www.nwhc.usgs.gov/research/west nile/ wnvaffected.html. Last modified 10/14/2003.

USGS. 2005. National Wildlife Health Center West Nile Virus Project. U.S. Geological Survey http://www.nwhc.usgs.gov/research/west_nile/west_nile.html. Last modified 3/23/2005.

Welsh, D. and Mayer, P. M. 1993. Concentrations of elements in eggs of least terns and piping plovers from the Missouri River, North Dakota. In Higgins, K. F. and Brashier, M. R, (eds.) Proceedings, The Missouri River and its tributaries: piping plover and least tern symposium. South Dakota State University, Brookings, SD.

Wershler, C. R. 1992. An analysis of piping plover management concerns in Alberta. Alberta NAWMP Centre, Edmonton, Alberta. Unpublished report. 56 pp.

Wershler, C, and Wallis, C. 1987. Status of the piping plover in Alberta, 1986. World Wildlife Fund Canada and Canadian Wildlife Service, Calgary, Alberta. Unpublished Report. 54 pp.

Whyte, A. J. 1985. Breeding ecology of the piping plover (Charadrius melodus) in central Saskatchewan. M.S. Thesis, University of Saskatchewan, Saskatoon, Saskatchewan.

Wiens, T. P. 1986. Nest site tenacity and mate retention in the piping plover. M.S. Thesis, University of Minnesota, Duluth. 34 pp.

Wilcox, L. 1959. A twenty year banding study of the piping plover. Auk 76: 129-152.

Wilcox, L. 1962. Oldest known shorebird in North America. Eastern Bird Banding Association News 25: 4546.

Wilkinson, P. M. and Spinks, M. 1994. Winter distribution and habitat utilization of piping plovers in South Carolina. Chat 58: 33-37.

Wilson, A. and Bonaparte, C. L. (no date). Piping Plover (Charadrius melodus). In: American Ornithology. Volume III. Cassell Petter and Galpin, New York.

Ziewitz, J. W., Sidle, J. G. and Dinan, J. J. 1992. Habitat conservation for nesting terns and piping plovers on the Platte River, Nebraska. Prairie Naturalist 24: 1-20. 


\section{APPENDIX 1}

\section{LIST OF ACRONYMS}

$\begin{array}{ll}\text { AOU } & \text { American Ornithological Union } \\ \text { BOR } & \text { Bureau of Reclamation } \\ \text { EQIP } & \text { Environmental Quality Incentives Program } \\ \text { GIS } & \text { Geographic Information System } \\ \text { MFWP } & \text { Montana Department of Fish, Wildlife and Parks } \\ \text { NRCS } & \text { National Resources Conservation Service } \\ \text { NWR } & \text { National Wildlife Refuge } \\ \text { PVA } & \text { Population Viability Analysis } \\ \text { USACE } & \text { United States Army Corp of Engineers } \\ \text { USDA } & \text { United States Department of Agriculture } \\ \text { USFWS } & \text { United States Fish and Wildlife Service } \\ \text { USGS } & \text { United States Geological Survey } \\ \text { WMD } & \text { Wetland Management District } \\ \text { WPA } & \text { Waterfowl Production Area }\end{array}$


APPENDIX 2

MONTANA LEAST TERN AND PIPING PLOVER WORK GROUP CONTACTS

\begin{tabular}{l|l}
\hline Name & Affiliation \\
\hline Dan Casey & American Bird Conservancy \\
Gayle Skunkcap, Director & Blackfeet Tribe \\
Bobby Baker & BLM \\
David Waller & BLM \\
Fritz Prellwitz & BLM \\
John Carlson & BLM-Glasgow Field Station \\
Justin Kucera & BOR \\
Sue Camp & BOR \\
Paul Backlund & BOR-Canyon Ferry \\
Steve Morehouse & BOR-Dillon \\
Blaskovich, Rick & BOR-Montana Area Office \\
Stan Huhtala & BOR-Tiber Dam \\
Dan Spencer & Bureau of Indian Affairs \\
Robbie Magnun, Director & Fort Peck Assiniboine \& Sioux Tribes \\
Debbie Madison & Fort Peck Tribes \\
Jim Thompson & Milk River Alliance \\
Monty Sullins & Montana Dept. of Agriculture \\
Arnold Dood & Montana Fish, Wildlife and Parks \\
Shirley Atkinson & Montana Fish, Wildlife and Parks \\
Brian Martin & Nature Conservancy \\
Jacob S. Ivan & Nature Conservancy \\
Wayne Harris & Saskatchewan Environment \\
Casey Kruse & US Army Corps of Engineers \\
Darin McMurry & US Army Corps of Engineers \\
Greg Pavelka & US Army Corps of Engineers \\
Vanessa Fields & US FWS-Benton Lake NWR \\
Lou Hanebury & USFWS (work group coordinator) \\
Jane Roybal & USFWS \\
Karen Kreil & USFWS-Bismarck \\
Kathy Tribby & USFWS-Bowdoin NWR \\
Glenn Guenther & USFWS-CMR \\
Everett Russell & USFWS-CMR \\
Lori Nordstrom & USFWS-ES \\
Bob Murphy, T\&E Specialist & USFWS-Lost Wood NWR \\
Beth Madden & USFWS-Medicine Lake NWR \\
Mike Rabenberg & USFWS-Medicine Lake NWR \\
Tim Connolly & nSFS-Medicine Lake NWR \\
Chuck Carlson & \\
\hline
\end{tabular}


APPENDIX 3

\section{DATASHEET FOR ANNUAL PIPING PLOVER BREEDING BIRD SURVEY IN MONTANA}

\section{PIPING PLOVER \\ MONTANA ANNUAL BREEDING BIRD SURVEY DATASHEET}

Date:

Observers:

Location:

Site Description:

GPS Location: $\mathrm{N}$ E

Number of plovers observed:

Number of plover pairs observed:

Activity

Courtship

Nesting

Defensive

Foraging

Flying

Other
Habitat Description

Sandbar

Gravelbar

Riverbank

Reservoir

Alkali wetland

Other $\underline{\text { Vegetation }}$

None

$>10 \%$

$10-14 \%$

$15-20 \%$

$>20 \%$ $\underline{\text { Substrate }}$

Gravel

Sand

Alkali

Other

Plant species present:

Other animal species present:

Evidence of predators:

Remarks: 


\title{
APPENDIX 4
}

\author{
INTERNATIONAL PIPING PLOVER \\ BREEDING CENSUS GUIDELINES AND DATASHEET
}

\author{
INTERNATIONAL PIPING PLOVER COORDINATION GROUP \\ 2001 INTERNATIONAL PIPING PLOVER BREEDING CENSUS \\ Guidelines
}

\begin{abstract}
General Purpose and History: The International Piping Plover Census, as designated by the International Piping Plover Coordination Group, has been established to provide a complete census of all Piping Plover populations on both wintering and breeding grounds every five years. The 2001 census is the third to be carried out over the past 10 years. The primary function of the census is to gather data for monitoring moderate-to-long-term population trends that will be used to assess success of recovery efforts and recovery objectives. Census data also provide information on the species' range and use of local habitat and may help elucidate migratory patterns. The first International Census, conducted in 1991, provided a population benchmark for the species status and distribution in North America. The breeding census included the efforts of hundreds of individuals in 22 U.S. states, nine Canadian provinces, and the French territory of St. Pierre and Miquelon. During the census period, 5,482 adult Piping Plovers (2,441 pairs) were documented. Subsequently, the 1996 census recorded 5,913 individuals (2,668 breeding pairs), an overall increase of $7.7 \%$ from 1991 . The 1996 census illustrated some striking regional trends, including a $31 \%$ increase in breeding birds along the Atlantic Coast, a $20 \%$ increase in the small Great Lakes population, and a 5\% decline in the U.S. Great Plains and the Canadian Prairie. The 2001 International Census will complement previous surveys, providing an even more refined picture of the breeding distribution of Piping Plovers. It will also provide the opportunity to assess ten-year trends for the species.
\end{abstract}

Census Dates: Ideally, we would like to have all censuses conducted during the same two weeks across North America, and within a time frame that facilitates comparisons to results obtained in previous surveys. Wherever possible, therefore, we ask that the census be undertaken between June $3^{\text {rd }}$ and June $16^{\text {th }}, 2001$ (except for the Atlantic U.S., which will census from May $26^{\text {th }}$ thru June $3^{\text {rd }}$ ). If that is not possible, successive weeks in June are also acceptable. We would appreciate discussing any plans for censuses conducted outside this time period.

Coordination: The 2001 census will be directed from USGS Forest and Rangeland Ecosystem Science Center in Corvallis, Oregon via Susan Haig (541-750-7482, email susan_haig@usgs.gov). She will maintain regular contact with other members of the International Piping Plover Coordination Team. Cheron Ferland (541-750-7390, email: cferland@usgs.gov) will be the primary coordinator for the census. State/Provincial Coordinators will organize census activities within each state/province and may designate local contact persons or coordinate all censusers directly. The responsibilities of each participant are outlined below:

1. Census Coordinator: Susan Haig will identify State/Provincial Coordinators and Cheron Ferland will provide them with census report forms, summary sheets, and assessment forms. Maps will not be distributed with the census information, as in previous censuses. It will be up to each state/provincial coordinator to submit site map(s) and a complete list of latitude and longitude coordinates for each site censused. Susan and Cheron will summarize census information and publicize results of both the winter and breeding censuses by Summer 2002. As in previous years, results will be presented in various formats:

- a technical paper submitted to a scientific journal

- a detailed report covering each state/province/country for distribution to recovery teams, state/provincial coordinators, and other natural resource agencies

- GIS-based maps and datasets posted on appropriate websites

- a popular article in a national/international birding magazine

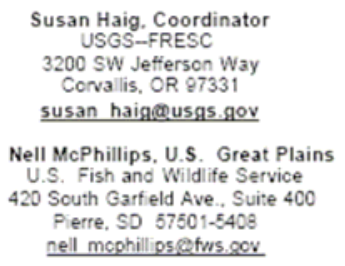

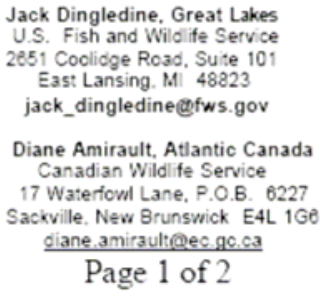

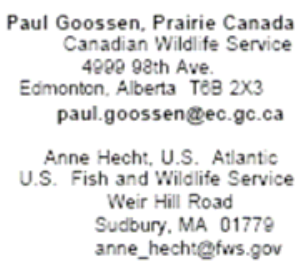


2. State/Provincial Coordinators: will identify censusers and areas to be surveyed. They will distribute census materials to individual censusers directly or through local contact persons. Following the census, they will summarize results and ensure that each site is mapped by latitude and longitude and provide a brief assessment of the census in their state/region.

Following completion of the census, Coordinators should send to Cheron Ferland:

- All Individual Census Reports/Maps

- State Summary Sheet

- State Assessment Form

We ask that this information be forwarded to Cheron Ferland by August $15^{\text {th }}, 2001$, and that we be informed of any delays as soon as possible. Maps of census sites should be turned in with the census summary. Each site should contain reference latitude and longitude coordinates (township and range information is not necessary).

3. Individual Censusers: will be given census guidelines and a census report form for each site they are to survey. Multiple individuals are encouraged to conduct censuses together. At least one individual censusing each site should be experienced in identification of shorebirds. Whenever possible, censuses of each site should be completed during one day. Multiple censuses of a site are not encouraged unless the original survey is considered to be inaccurate because of adverse weather conditions, human disturbance, etc. Census reports should be filled out as completely as possible for all censuses at each site and returned to the state/provincial coordinator by the specified date. Maps should also be returned to the coordinator with the census area clearly marked and labeled, including latitude and longitude of approximate site center. Specific locations where Piping Plovers are observed may also be indicated on maps. Census reports and maps should be returned even if no Piping Plovers were observed

Census methods: The goal of the census is to count both breeding pairs and unpaired adults. Pairs should only include birds seen together. Single birds in the presence of nests or young should be tallied separately from other unpaired birds; however, we discourage censusers from searching for nests or young in order to minimize disturbance to breeding sites. We are specifically not addressing issues of reproductive success during this census. We are not providing specific instructions for conducting individual censuses but include the following definitions and suggestions. Sites may include individual wetlands, lakes, or stretches of river or coastline or any portion of the above. Sites should be censused by the most effective means possible. Care should be taken to note where birds have flown to and from in order to avoid double counting. This is especially important because Piping Plovers (in the northern Great Plains and Prairie) often flock when intruders enter a nesting area. Avoid conducting surveys during extreme weather conditions, which not only results in inaccurate census data, but also increases risks of disturbance to the birds. Surveys are best conducted during early morning hours, although we understand that confining censuses to this time period is often unrealistic. Censusers should avoid encroaching on nesting territories when possible and in all cases should limit time spent in any single territory to no more than 5 minutes. Please try to minimize disturbance to the birds!

Census priorities: Ideally, all habitat recently and/or currently suitable for Piping Plovers should be surveyed in 2001. Due to lack of information about sites or other constraints, however, this goal may not be achievable in some states/provinces. To meet census objectives, we therefore suggest the following priorities: 1) Sites that had Piping Plovers present in 1991, 1996 or later. 2) Sites that had suitable Piping Plover habitat in 1991 and 1996. 3) Sites that were unsuitable when censused in 1996 but that have been suitable more recently. 4) Sites not censused in 1996 but that are likely to contain suitable Piping Plover habitat. 5) Sites not censused in 1996 but with historic records of use by Piping Plovers. To most accurately analyze population trends over the past ten years, at least the first three priorities need to be met.

We thank you for your involvement with the 2001 International Piping Plover Census! Each census is extremely important in allowing us to monitor recovery efforts for this species. 


\section{INTERNATIONAL PIPING PLOVER COORDINATION GROUP}

\section{INTERNATIONAL PIPING PLOVER BREEDING CENSUS Individual Census Report}

Please complete this form as thoroughly as possible for each location surveyed, even if Piping Plovers are not found. Attach a map or detailed description of the area censused, including latitude and longitude of survey area (approximate site center). Also feel free to attach additional comments. These forms should be sent to your State/Provincial Coordinator by July 15,2001. For further information, contact your State/Provincial Coordinator or Cheron Ferland @USGS-BRD Forest and Rangeland Ecosystem Science Center, 3200 SW Jefferson Way, Corvallis, OR 97331 USA; 541-750-7390; cferland@usgs.gov; FAX 541-758-7761.

1. Total $\#$ of pairs of Piping Plovers seen Pair criteria used (check all that apply)

Courtship behavior Pair at nest

Joint defensive behavior Pair with young

Birds located together

Other (describe)

2. Total $\nRightarrow$ of unpaired adults: with nest/young: no nest/young seen

3. Census Location

Local name of site:

County State/Province:

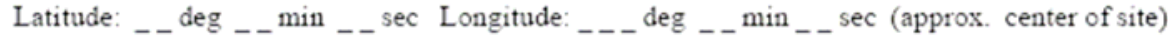
River Miles (Missouri, Niobrara, and Platte Rivers only): Map(s) (USGS topo quad; atlas/gazetteer grid \#; etc.):

Land Ownership: Federal State/Provincial Municipal Private

4. Date of census:

Time census conducted to

5. Conditions:

Tide stage(s): $\quad$ Low _ Mid__ High__ (Rising_/Falling__) General weather: Overcast_ Rain _ Fog _ Other

Approximate temperature: Wind speed: Sunny _ _ Partsius/Fahrenheit (circle one)

_ $\mathrm{km} / \mathrm{hr}$ miles/hr (circle one) Wind direction

6. Habitat censused (check as many as apply):

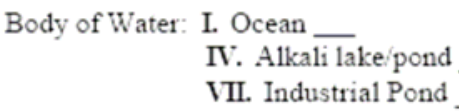

Shoreline:
A. Mainland
E. Other island

Substrate(s):
1. Sand beach __

5. Silt

9. Vegetated shoreline

12. Other (describe)
II. Protected bay, harbor, cove, lagoon __ III.River V. Natural freshwater lake VIII. Other (describe)

B. Barrier island

F. Dry lake bed

C. Spoil island

G. Other (describe) VLReservoir

2. Sand spit 6. Gravel shore
3. Sand dune 7. Gravel bar

4. Sand bar 8. Gravel pit 1. Coastal mudflat

\footnotetext{
Susan Faig. Coordiasto: USGS-FRESC 200 SW Jefferson Way Corvalis, OR 97331 susan_haig@usgs.gov

Nell McPhillips, U.S. Great Plain: U.S. Fish and Wildife Service 420 South Garfield Ave.. Suite 400 Pierre, SD $57501-5408$

\begin{tabular}{|c|}
\hline $\begin{array}{l}\text { Jack Dicgledice, Great Lakes } \\
\text { U.S. Fish and Wildife Service } \\
2851 \text { Coolidge Road, Suite } 101 \\
\text { East Lansing. MI } 48823 \\
\text { jack_dingledine@ fws.gov }\end{array}$ \\
\hline $\begin{array}{l}\text { Diape Amirault, Atlaztic Cazada } \\
\text { Canadian Wildife Service } \\
17 \text { Waterfowi Lane, P.O.B. } 6227 \\
\text { Sackville. New Brunswick E4L } 1 \text { Ge }\end{array}$ \\
\hline
\end{tabular}
nell_mcphillips @efws.gov
}

10. Alkali mudflat diane.amirault@ec.gc.ca

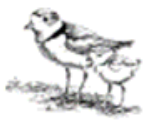
. 
7. Habitat(s) where Piping Plovers found (use above designations; e.g., IIC8, IIIB9):

8.

Mode(s) of transportation: Fod

Foot

Car/Truck

ATV

Boat

Airboat

9. Linear Habitat (shoreline) covered. $\mathrm{km} /$ miles (circle one)

Was census completed for this area? yes _ no _ W What percentage was missed?

What areas were missed?

10

Was site censused in 1991 ? Yes __ No _

Was site censused in 1996 ? Yes __ No

If "yes," how does coverage differ from earlier surveys?

Were there any circumstances that may have affected census results (weather conditions, human disturbance, etc.)?

Band combinations of any marked birds (right leg:left leg from top to bottom; note colors, flags or bands, etc.)

Describe any apparent injuries of banded or unbanded birds.

14. Number of people censusing

Censusers names, affiliations, phone numbers, email, \& addresses: (attach additional list if necessary)

-

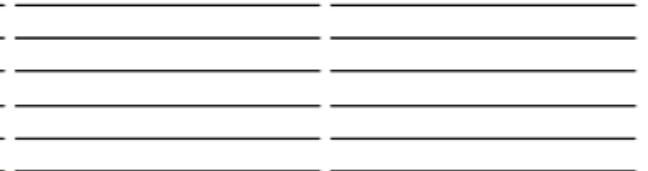

15. Additional information/comments:

THANKS FOR YOUR HELP WITH THE 2001 INTERNATIONAL PIPING PLOVER CENSUS!! 


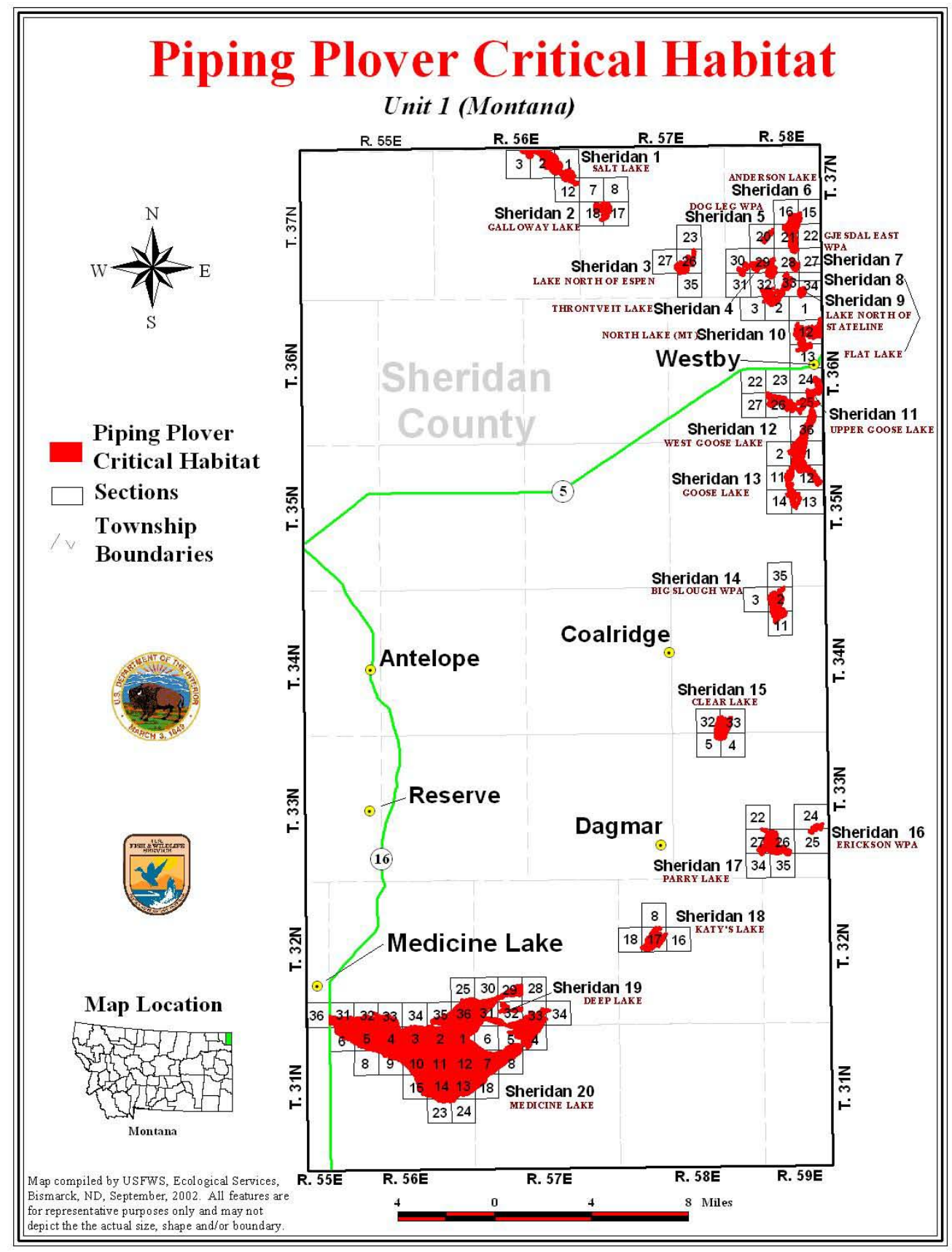

Critical habitat MT-1 Sheridan County, Montana.

Courtesy: USFWS, Ecological Services. 


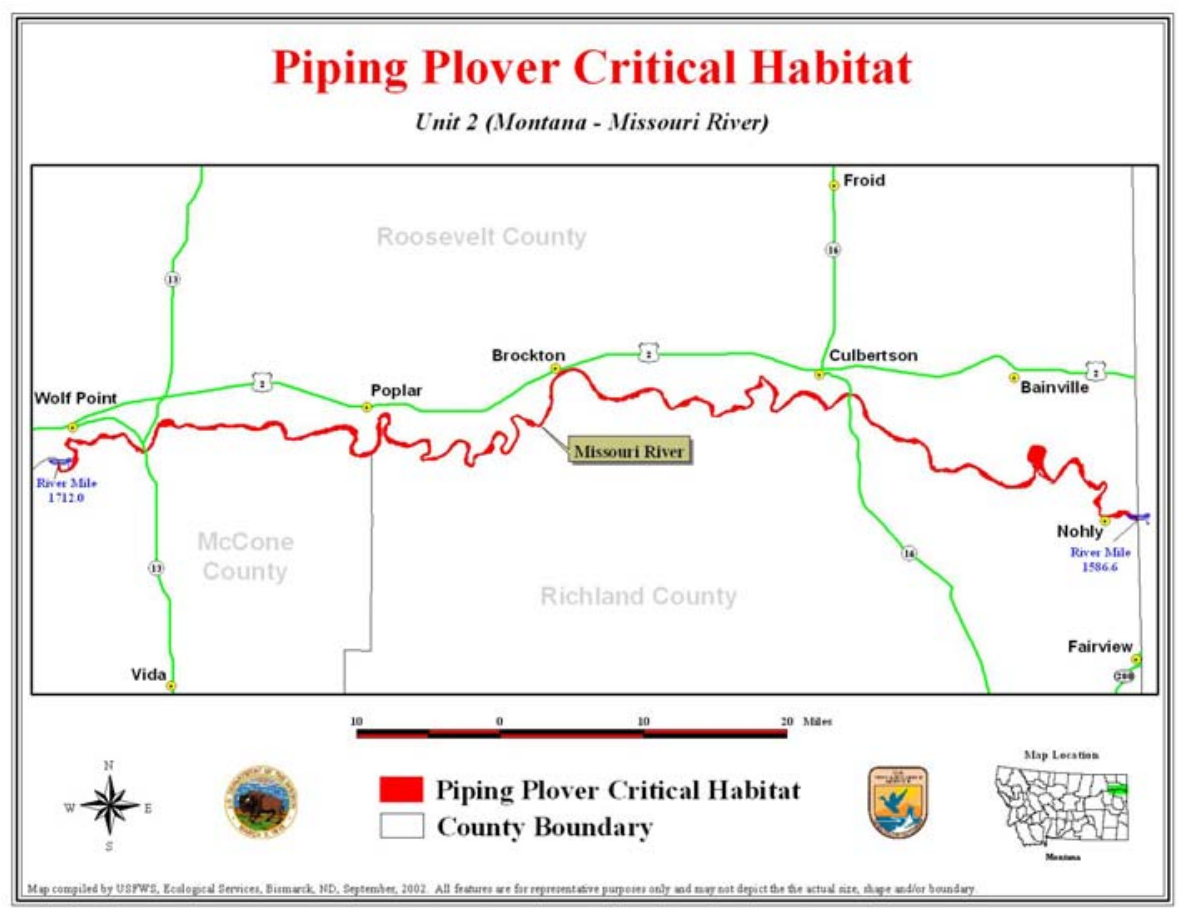

Critical Habitat MT-2 Missouri River, Montana.

Courtesy: USFWS, Ecological Services.

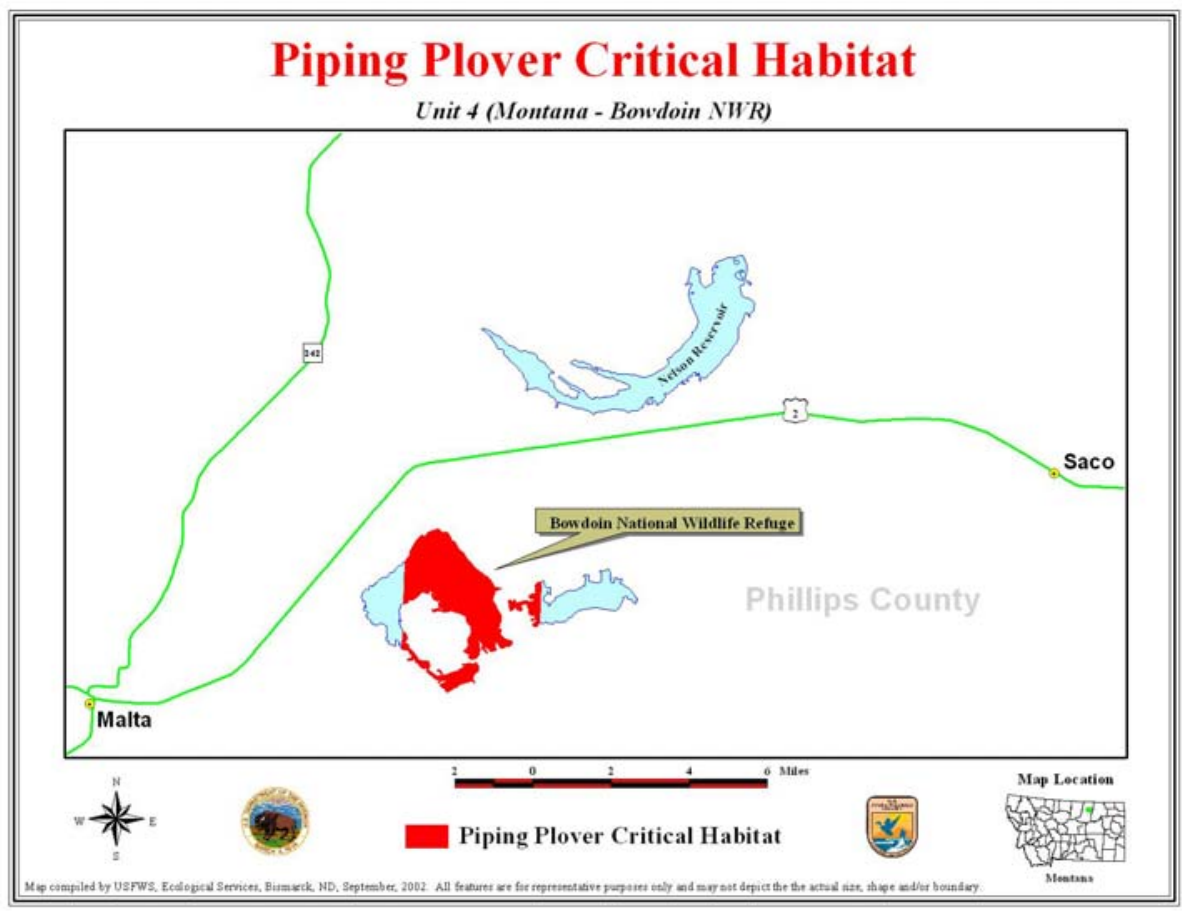

Critical Habitat MT-4 Bowdoin National Wildlife Refuge, Montana. Courtesy USFWS, Ecological Services. 


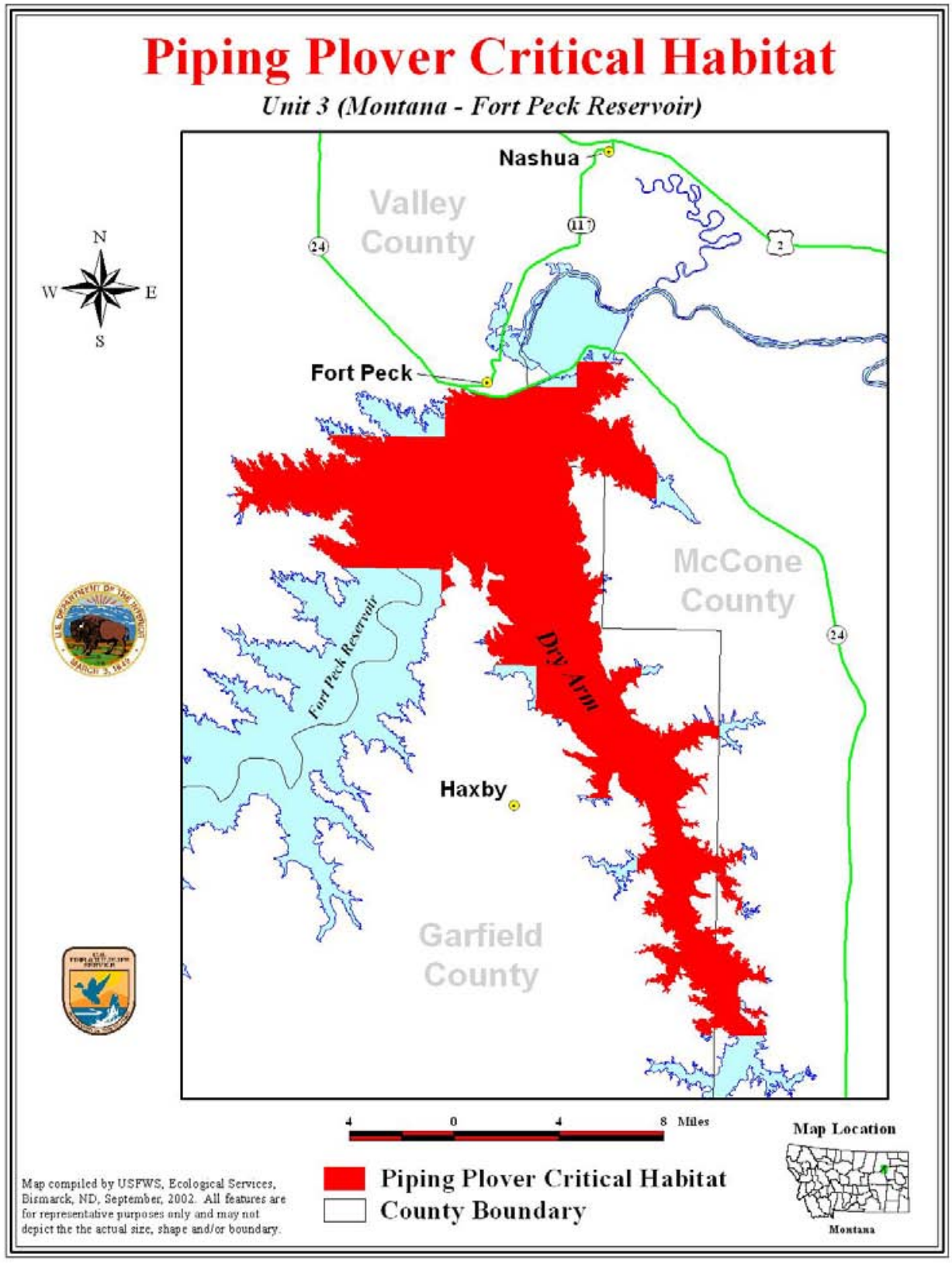

Critical habitat MT-3 Fort Peck Reservoir, Montana.

Courtesy: USFWS, Ecological Services. 

100 copies of this public document were published at an estimated cost of $\$ 14.47$ per copy, for a total cost of $\$ 1,447.00$, which includes $\$ 1,447.00$ for printing and $\$ 0.00$ for distribution. 